San Jose State University

SJSU ScholarWorks

Master's Theses

Master's Theses and Graduate Research

1989

\title{
An assessment of the groundwater nutrient and freshwater contribution to Tomales Bay, Western Marin County, California
}

Michael Anthony Valentino

San Jose State University

Follow this and additional works at: https://scholarworks.sjsu.edu/etd_theses

\section{Recommended Citation}

Valentino, Michael Anthony, "An assessment of the groundwater nutrient and freshwater contribution to Tomales Bay, Western Marin County, California" (1989). Master's Theses. 3231.

DOI: https://doi.org/10.31979/etd.v5sf-7bgu

https://scholarworks.sjsu.edu/etd_theses/3231

This Thesis is brought to you for free and open access by the Master's Theses and Graduate Research at SJSU ScholarWorks. It has been accepted for inclusion in Master's Theses by an authorized administrator of SJSU ScholarWorks. For more information, please contact scholarworks@sjsu.edu. 


\section{INFORMATION TO USERS}

The most advanced technology has been used to photograph and reproduce this manuscript from the microfilm master. UMI films the text directly from the original or copy submitted. Thus, some thesis and dissertation copies are in typewriter face, while others may be from any type of computer printer.

The quality of this reproduction is dependent upon the quality of the copy submitted. Broken or indistinct print, colored or poor quality illustrations and photographs, print bleedthrough, substandard margins, and improper alignment can adversely affect reproduction.

In the unlikely event that the author did not send UMI a complete manuscript and there are missing pages, these will be noted. Also, if unauthorized copyright material had to be removed, a note will indicate the deletion.

Oversize materials (e.g., maps, drawings, charts) are reproduced by sectioning the original, beginning at the upper left-hand corner and continuing from left to right in equal sections with small overlaps. Each original is also photographed in one exposure and is included in reduced form at the back of the book.

Photographs included in the original manuscript have been reproduced xerographically in this copy. Higher quality $6 "$ " 9 9" black and white photographic prints are available for any photographs or illustrations appearing in this copy for an additional charge. Contact UMI directly to order.

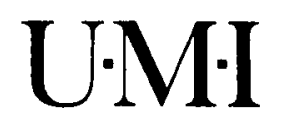

University Microfilms International

A Bell \& Howell Information Company

300 North Zeeb Road. Ann Arbor, MI 48106-1346 USA

$313 / 761-4700 \quad 800 / 521-0600$ 
- 
Order Number 1939657

An assessment of the groundwater nutrient and freshwater contribution to Tomales Bay, western Marin County, California

Valentino, Michael Anthony, M.S.

San Jose State University, 1989 


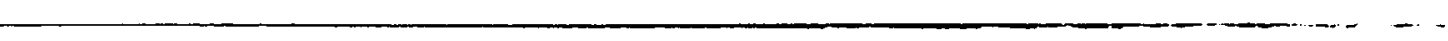




\title{
AN ASSESSMENT OF THE GROUNDWATER \\ NUTRIENT AND FRESHWATER CONTRIBUTION TO \\ TOMALES BAY, WESTERN MARIN COUNTY, CALIFORNIA
}

\author{
A Thesis \\ Presented to \\ The Faculty of the Department of Geology \\ San Jose State University \\ In Partial Fulfillment \\ of the Requirements for the Degree \\ Master of Science
}

By

Michael Anthony Valentino

December, 1989 


\section{APPROVED FOR THE DEPARTMENT OF: GEOLOGY}

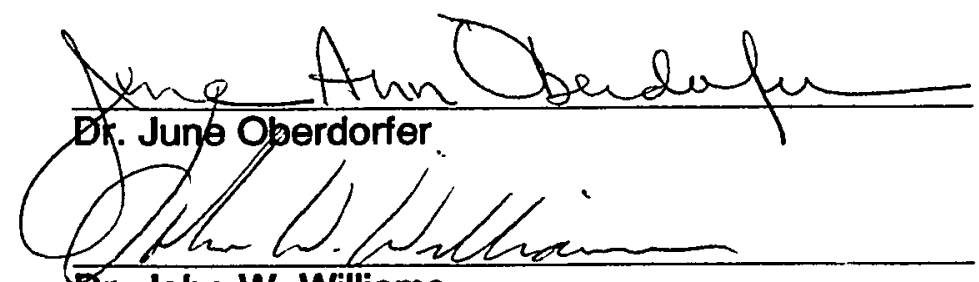

Dr. John W. Williams

Debrak R Hard

Dr. Deborah Harden

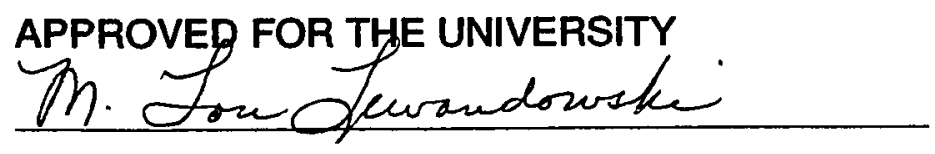




\section{ACKNOWLEDGEMENTS}

Assistance from the following individuals and institutions is gratefully acknowleged: Dr. Steve Smith, University of Hawaii; Analytical Services at the Hawaii Institute of Marine Biology; The National Science Foundation; Tim Hollibaugh, USGS Menlo Park; Arthur Marthinson, Marin County Environmnental Health Dept.; William Wilson, North Marin Municipal Water District; Carl Hague and the staff at the California Department of Water Resources, Sacramento; Dr. June Oberdorfer, Dr. Deborah Harden, and Dr. John Williams, San Jose State University; Larry Byrwa, Graphics Dept., Harrison High School; Avis Francis, Gibbs and Hill Inc.; and Jill and Anthony Valentino for the financial assistance needed to çomplete this thesis.

Appreciation is extended to the people of the Tomales Bay area who allowed me to take water samples from their wells and were always willing to talk or provide information concerning the environmental health of Tomales Bay and nearby watersheds. 


\section{TABLE OF CONTENTS}

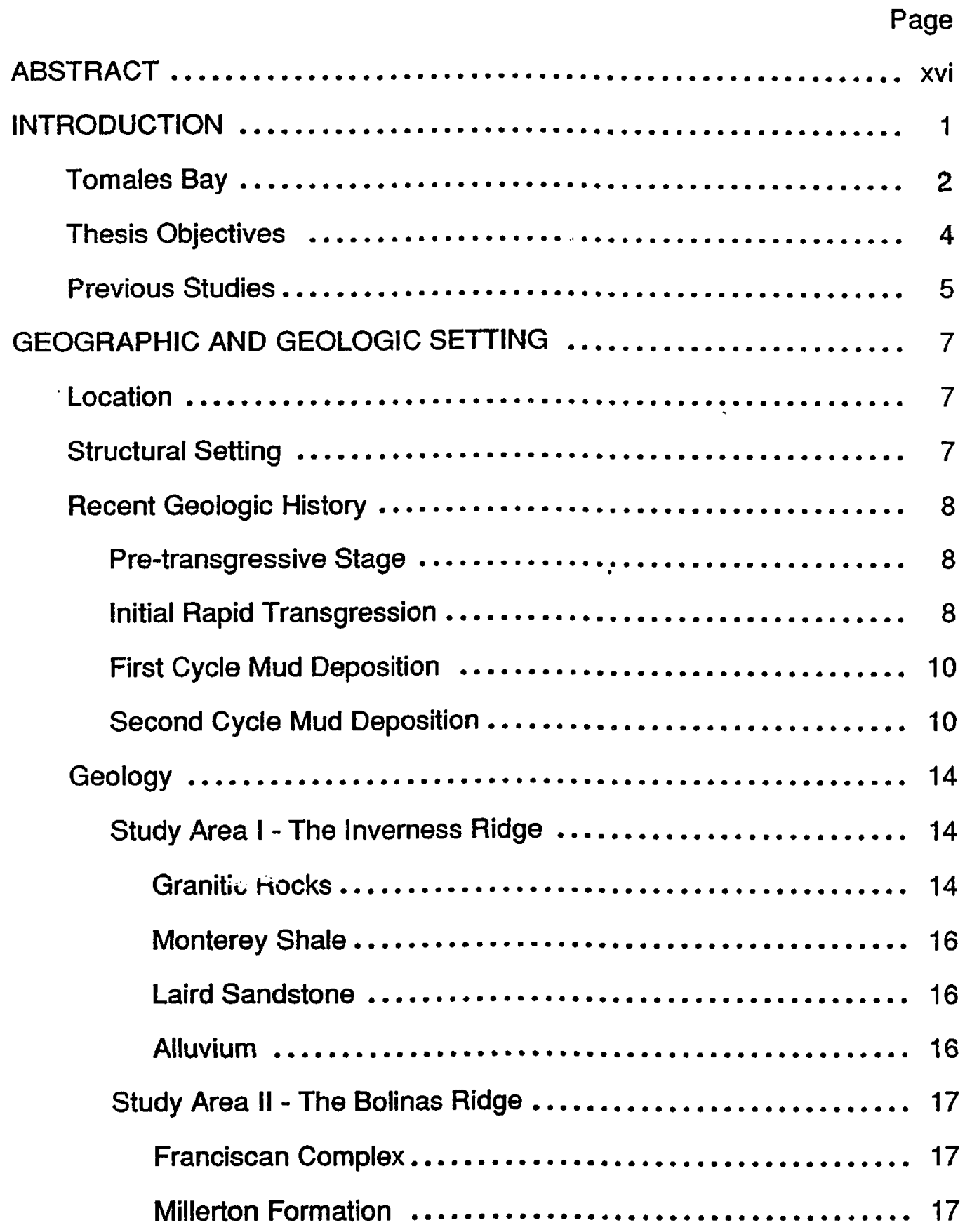


Page

Merced Formation ............................ 18

Alluvium .................................... 18

Study Area III - The San Andreas Trough ............... 18

Alluvium ...................................... 18

Stream Terrace Deposits $\ldots \ldots \ldots \ldots \ldots \ldots \ldots \ldots \ldots \ldots \ldots \ldots .18$

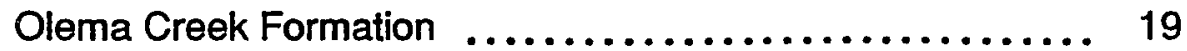

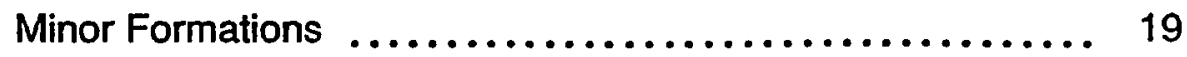

HYDROGEOLOGY - GROUNDWATER OCCURRENCE .......... 20

Study Area $I$ - The Inverness Ridge .................... 20

Study Area II - The Bolinas Ridge ..................... 21

Study Area III - The San Andreas Trough ................... 21

SURFACE WATER HYDROLOGY $\ldots \ldots \ldots \ldots \ldots \ldots \ldots \ldots \ldots \ldots, 23$

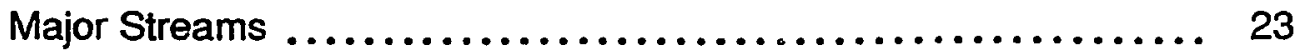

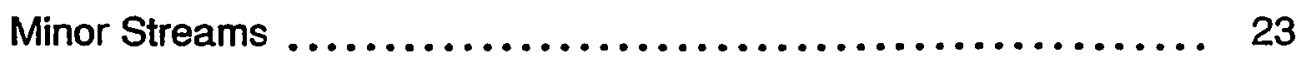

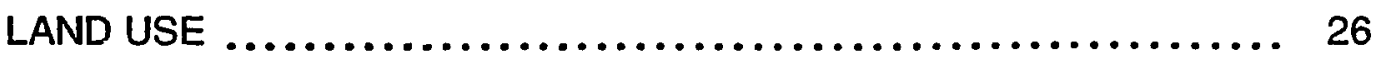

Water Supply $\ldots \ldots \ldots \ldots \ldots \ldots \ldots \ldots \ldots \ldots \ldots \ldots \ldots \ldots \ldots . \ldots \ldots$

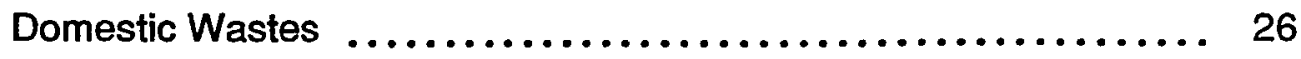

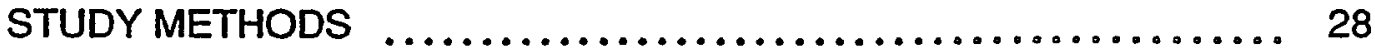

Well Water Sampling Procedures $\ldots . \ldots \ldots \ldots \ldots \ldots \ldots \ldots \ldots . . \ldots 28$

Water Quality Analytical Procedures ...................... 29

Field Analytical Techniques .......................... 29

Laboratory Analytical Procedures ...................... 29

Statistical Analysis of Nutrient Data $\ldots \ldots \ldots \ldots \ldots \ldots \ldots \ldots .30$

Quantification of Groundwater Discharge Rate ............ 30 
Soil Moisture Budget Method $. \ldots \ldots \ldots \ldots \ldots \ldots \ldots \ldots \ldots \ldots . \quad 30$

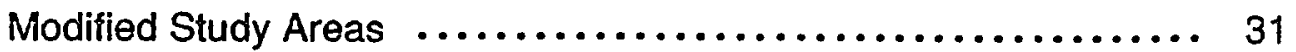

Generalized Soils Map $. \ldots \ldots \ldots \ldots \ldots \ldots \ldots \ldots \ldots \ldots \ldots . \quad 31$

Average Available Water Capacities..$\ldots \ldots \ldots \ldots \ldots \ldots \ldots \ldots .34$

Soil Depth Ranges $\ldots \ldots \ldots \ldots \ldots \ldots \ldots \ldots \ldots \ldots \ldots \ldots \ldots \ldots, 36$

Runoff Rates $\ldots \ldots \ldots \ldots \ldots \ldots \ldots \ldots \ldots \ldots \ldots \ldots \ldots \ldots \ldots, \quad 37$

Evapotranspiration Rates $\ldots \ldots \ldots \ldots \ldots \ldots \ldots \ldots \ldots \ldots \ldots . \quad 39$

Precipitation Averages $. \ldots \ldots \ldots \ldots \ldots \ldots \ldots \ldots \ldots \ldots \ldots \ldots \ldots, 41$

Recharge and Discharge Estimates.................. 44

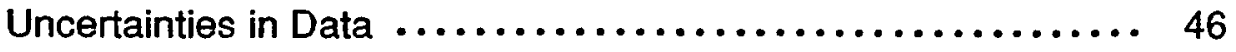

Darcy's Law Method................................ 48

Transmissivity $. \ldots \ldots \ldots \ldots \ldots \ldots \ldots \ldots \ldots \ldots \ldots \ldots \ldots, 49$

Discharge Length $\ldots \ldots \ldots \ldots \ldots \ldots \ldots \ldots \ldots \ldots \ldots \ldots \ldots, 50$

Hydraulic Head Gradient.$\ldots \ldots \ldots \ldots \ldots \ldots \ldots \ldots \ldots \ldots \ldots .650$

Uncertainties In Data ........................... 50

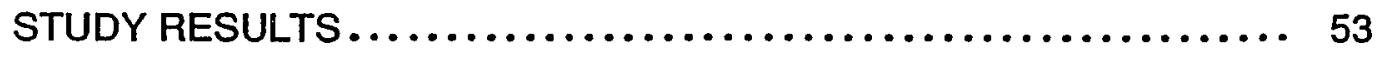

Quantification of Groundwater Discharge Rate .............. 53

Soil Moisture Budget Discharge Rate $\ldots \ldots \ldots \ldots \ldots \ldots \ldots \ldots \ldots, 53$

Darcy's Law Discharge Rate..$\ldots \ldots \ldots \ldots \ldots \ldots \ldots \ldots \ldots .656$

Combined Groundwater Discharge Rates.............. 56

Nutrient Concentrations $\ldots \ldots \ldots \ldots \ldots \ldots \ldots \ldots \ldots \ldots \ldots \ldots \ldots, 56$

Phosphate $\ldots \ldots \ldots \ldots \ldots \ldots \ldots \ldots \ldots \ldots \ldots \ldots \ldots \ldots, 58$

Nitrate - Nitrite $\ldots \ldots \ldots \ldots \ldots \ldots \ldots \ldots \ldots \ldots \ldots \ldots \ldots \ldots, 61$

Ammonium $. \ldots \ldots \ldots \ldots \ldots \ldots \ldots \ldots \ldots \ldots \ldots \ldots \ldots \ldots, 64$

Silica $\ldots \ldots \ldots \ldots \ldots \ldots \ldots \ldots \ldots \ldots \ldots \ldots \ldots \ldots \ldots \ldots \ldots .64$ 


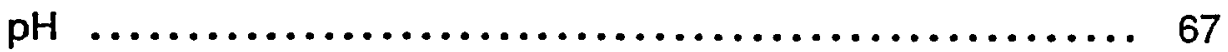

Alkalinity $\ldots \ldots \ldots \ldots \ldots \ldots \ldots \ldots \ldots \ldots \ldots \ldots \ldots \ldots, 67$

Dissolved Inorganic Carbon.$\ldots \ldots \ldots \ldots \ldots \ldots \ldots \ldots \ldots \ldots .67$

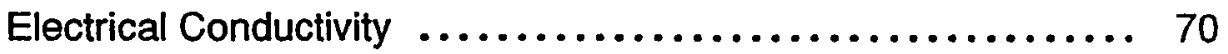

Groundwater Nutrient Loading $\ldots \ldots \ldots \ldots \ldots \ldots \ldots \ldots \ldots \ldots . \quad 70$

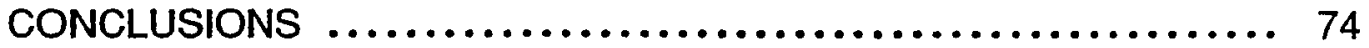

Assessment of Freshwater Contribution $\ldots \ldots \ldots \ldots \ldots \ldots \ldots \ldots . \quad 74$

Winter Period - November to March................. 74

Summer Period - April to October $\ldots \ldots \ldots \ldots \ldots \ldots \ldots \ldots \ldots .74$

Significance of Freshwater Discharge $\ldots \ldots \ldots \ldots \ldots \ldots \ldots \ldots .77$

Assessment of Nutrient Loading $\ldots \ldots \ldots \ldots \ldots \ldots \ldots \ldots \ldots \ldots \ldots, 77$

Winter Period - November to March $\ldots \ldots \ldots \ldots \ldots \ldots \ldots \ldots . .68$

Summer Period - April to October.................... 81

Walker Creek ................................. 81

Ocean Advection/Groundwater Comparison............. 81

Ocean Mixing/Groundwater Comparison $\ldots \ldots \ldots \ldots \ldots \ldots \ldots .61$

Future Studies $\ldots \ldots \ldots \ldots \ldots \ldots \ldots \ldots \ldots \ldots \ldots \ldots \ldots \ldots \ldots, 83$

Seepage Flux Meters $\ldots \ldots \ldots \ldots \ldots \ldots \ldots \ldots \ldots \ldots \ldots \ldots .63$

Detailed Testing and Monitoring $\ldots \ldots \ldots \ldots \ldots \ldots \ldots \ldots \ldots .83$

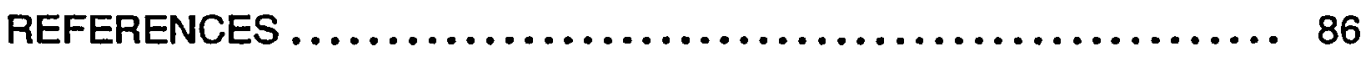

APPENDIX A: Generalized Soil Descriptions ................. 89

APPENDIX B: Evapotranspiration Maps .................... 94

APPENDIX C: Water Quality Data ........................ 107

APPENDIX D: Tables for Soil Moisture Budget $\ldots \ldots \ldots \ldots \ldots \ldots \ldots \ldots .115$ 


\section{LIST OF ILLUSTRATIONS}

$\begin{array}{ll}\text { Figure Page } & \text { Page }\end{array}$

1. Location Map ............................... 3

2. Pre-transgressive Stage $\ldots \ldots \ldots \ldots \ldots \ldots \ldots \ldots \ldots \ldots \ldots \ldots . \ldots 9$

3. Initial Rapid Transgression - First Cycle

Mud Deposition ................................ 11

4. End of First Cycle Mud Deposition $\ldots \ldots \ldots \ldots \ldots \ldots \ldots \ldots \ldots \ldots$

5. Second Cycle Mud Deposition .................... 13

6. Study Area Map $\ldots \ldots \ldots \ldots \ldots \ldots \ldots \ldots \ldots \ldots \ldots \ldots \ldots \ldots$

7. Major Streams in the Tomales Bay Watershed............... 24

8. Input and Output Variables for the Soil. Moisture Budget Method ............................ 32

9. Modified Study Areas Map ....................... 33

10. Location of Rain Gage Stations in the

Tomales Bay Region .......................... 43

11. Average Phosphate Concentrations ..................60

12. Flow Chart of the Nitrogen Cycle ................... 62

13. Average Nitrate-Nitrite Concentrations ................ 63

14. Average Ammonium Concentrations $\ldots \ldots \ldots \ldots \ldots \ldots . \ldots 6$

15. Average Silica Concentrations .................... 66

16. Average $\mathrm{pH} \ldots \ldots \ldots \ldots \ldots \ldots \ldots \ldots \ldots \ldots \ldots \ldots \ldots \ldots \ldots . \ldots \ldots \ldots$

17. Average Alkalinity ........................... 69

18. Average Dissolved Inorganic Carbon .................. 71

19. Average Conductivity ......................... 72

20. Freshwater Loading to Tomales Bay ................. 76 
Figure

21. A Comparison of Groundwater and Stream Water Winter Nutrient Loading to Tomales Bay

22. A Comparison of Groundwater and Stream Water Summer Nutrient Loading to Tomales Bay

23. Groundwater Nutrient Loading Compared to Ocean Advection Nutrient Loading

24. Groundwater Nutrient Flux Compared to Ocean Mixing Nutrient Flux

25. A Diagram of a Seepage Meter

26. Monthly Evapotranspiration Isoline Map for California, January

27. Monthly Evapotranspiration Isoline Map for California, February

28. Monthly Evapotranspiration Isoline Map for California, March

29. Monthly Evapotranspiration Isoline Map for California, April

30. Monthly Evapotranspiration Isoline Map for California, May

31. Monthly Evapotranspiration Isoline Map for California, June.

32. Monthly Evapotranspiration Isoline Map for California, July

33. Monthly Evapotranspiration Isoline Map for California, August

34. Monthly Evapotranspiration Isoline Map for California, September

35. Monthly Evapotranspiration Isoline Map for California, October

36. Monthly Evapotranspiration Isoline Map for California, November 105

37. Monthly Evapotranspiration Isoline Map for California, December 
Plate

1. Geologic Map of the Tomales Bay Watershed ......... In Pocket

2. Generalized Soils Map of the Tomales Eay

Watershed ............................. In Pocket

3. Sampled Well Locations in the Tomales Bay

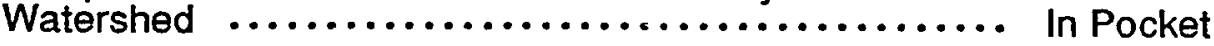

4. Isohyetal Map of Marin County $\ldots \ldots \ldots \ldots \ldots \ldots \ldots$ In Pocket

5. Depths of Water in Wells of the Inverness

Area ................................... In Pocket 


\section{LIST OF TABLES}

Table

Page

1. Flow Rates for Lagunitas Creek and Walker Creek........... 25

2. An Example of the Physical and Chemical Properties Table for Two Specific Soils

3. Average Water Capacity and Soil Depth for Each

Soil in the Tomales Bay Watershed

4. Average Monthly Runoff Rates for the Tomales

Bay Watershed

5. Monthly Evapotranspiration Rates for San Rafael, Fort Ross, the San Rafael-Fort Ross Average, Tomales Bay, and the Average Between Tomales

Bay and the San Rafael-Fort Ross Average

6. Monthly Precipitation Averages for Tomales, Inverness, Pt. Reyes Sta., Kentfield, Study

Area I, Study Area II, and Study Area III

7. Transmissivity Values for Study Area I and

Study Area II

8. Map Area, Actual Area, Lower and Upper Limit

Recharge Rate, and Lower and Upper Limit

Discharge Rate for Each Study Area's

Soil in the Tomales Bay Watershed

9. Discharge Rates from Each Study Area for

Water Budget Lower Limit and Water Budget

Upper Limit

10. Darcy's Law Groundwater Discharge Averages

for Each Study Area

11. Means and Standard Deviations for Phosphate,

Nitrate-Nitrite, Ammonium, Silica, $\mathrm{pH}$,

Alkalinity, Conductivity, and Temperature

12. Groundwater Nutrient Loading to Tomales Bay ............. 73

13. Summer and Winter Groundwater Contribution

of Freshwater to Tomales Bay 
14. Calculated Steady-State Net Fluxes of Dissolved $\mathrm{Si}, \mathrm{PO}_{4}, \mathrm{NO}_{3}$, and $\mathrm{DIC}$, Inner Tomales Bay, Late Summer 1985

15. Stream Water Nutrient Concentrations ................. 75

16a. Winter Groundwater Nutrient Loading to Tomales Bay ....... 79

16b. Summer Groundwater Nutrient Loading to Tomales Bay ...... . 79

17. Concentrations of Phosphate, Nitrate-Nitrite, Ammonium, Silica, and Dissolved Inorganic Carbon in the Wells and Springs

Sampled Within the Tomales Bay Watershed

18. Values of $\mathrm{pH}$, Alkalinity, Conductivity, and

Temperature in the Wells and Springs Sampled

Within the Tomales Bay Watershed

19a. Estimate of Lower Limit Groundwater Recharge from Precipitation for Kehoe-Inverness-Sheridan Variant Soil in Study Area

19b. Estimate of Upper Limit Groundwater Recharge from Precipitation for Kehoe-Inverness-Sheridan Variant Soil in Study Area 1

20. Estimate for Groundwater Recharge from Precipitation for Bulcher-Cole Soil in

Study Area II

21. Estimate for Groundwater Recharge from

Precipitation for Duneland-Sirdrak Soil in Study Area II

22a. Estimate of Lower Limit Groundwater Recharge from Precipitation for Olompali-Soulajoule-Felton Variant Soil in Study Area II

22b. Estimate of Upper Limit Groundwater Recharge from Precipitation for Olampali-Soulajoule-Felton Variant Soil In Study Area II

23a. Estimate of Lower Limit Groundwater Recharge from Precipitation for Tocaloma-Saurin Soil in Study Area II 
23b. Estimate of Upper Limit Groundwater Recharge from Precipitation for Tocaloma-Saurin Soil

in Study Area II.

24a. Estimate of Lower Limit Groundwater Recharge from Precipitation for Los Osos-Bonnydoon Soil in Study Area II

24b. Estimate of Upper Limit Groundwater Recharge from Precipitation for Los Osos-Bonnydoon Soil in Study Area II

25. Estimate of Groundwater Recharge from Precipitation for Bulcher-Cole Soil in Study Area III

26a. Estimate of Lower Limit Groundwater Recharge from Precipitation for Kehoe-Inverness-Sheridan Variant Soil in Study Area III

26b. Estimate of Upper Limit Groundwater Rectiarge from Precipitation for Kehoe-Inverness-Sheridan Variant

Soil in Study Area III . . . . . . . . . . . . . . . . . . . . . . . . . . .

27a. Estimate of Lower Limit Groundwater Recharge from Precipitation for Palomarin-Wittenberg Soil in

Study Area III

27b. Estimate of Upper Limit Groundwater Recharge from Precipitation for Palomarin-Wittenberg Soil in Study Area III

28a. Estimate of Lower Limit Groundwater Recharge from Precipitation for Cronkite-Dipsea-Centissima Soil in Study Area III

28b. Estimate of Upper Limit Groundwater Recharge from Precipitation for Cronkite-Dipsea-Centissima Soil in Study Area III

29a. Estimate of Lower Limit Groundwater Recharge from Precipitation for Olompali-Soulajoule-Felton

Variant So:l in Study Area III

29b. Estimate of Upper Limit Groundwater Recharge from Precipitation for Olompali-Soulajoule-Felton

Variant Soil in Study Area III. 
30a. Estimate of Lower Limit Groundwater Recharge from Precipitation for Tocaloma-Saurin Soil in Study Area III

30b. Estimate of Upper Limit Groundwater Recharge from Precipitation for Tocaloma-Saurin Soil in Study Area III

31a. Estimate of Lower Limit Groundwater Recharge from Precipitation for Los Osos-Bonnydoon Soil in Study Area III

31b. Estimaite of Upper Limit Groundwater Recharge from Precipitation for Los Osos-Bonnydoon Soil in Study Area III 


\section{ABSTRACT}

Groundwater can play an important role in contributing freshwater and nutrients to lakes and bays. One area where groundwater is an important contributor is Tomales Bay, California. Tomales Bay, a drowned portion of the San Andreas rift zone, was chosen because its linear shape allows for simple modelling and it is relatively pristine. The geology of the region is complex due to right lateral movement along the San Andreas Fault. The fault separates the granitic rocks on the west from the Franciscan rocks on the east. Alluvium fills the San Andreas trough on the south. Because of these geological differences, the Tomales Bay region was divided into three study areas: Study Area I, the western granitic rocks; Study Area II, the eastern Franciscan rocks; and Study Area III, the southern alluvial-filled, San Andreas trough.

To estimate groundwater nutrient concentrations, wells were sampled in the Tomales Bay watershed for their phosphate, nitrate-nitrite, ammonium, silica, and dissolved inorganic carbon (DIC) concentrations. Two methods were used to estimate the groundwater contribution to Tomales Bay: a soil moisture budget method and a Darcy's Law method. The final groundwater nutrient loading was obtained by multiplying the groundwater freshwater contribution by the nutrient concentrations.

As compared to surface water, groundwater contributes a significant amount of the total loading of phosphate, nitrate-nitrite, and ammonium, on the order of $55 \%-90 \%$, and smaller amounts of Silica and DIC, approximately $30 \%$ during the summer months (April-October). 
Groundwater, compared to surface water, contributes approximately $10 \%$ of the nutrient loading to Tomales Bay during the winter months (November-March).

Groundwater is also important in the nutrient loading process when compared to ocean advection. It contributes significantly more $\mathrm{NO}_{3}, \mathrm{NH}_{4}$, and $\mathrm{Si}$ and slightly more DIC to Tomales Bay. Ocean advection contributes more $\mathrm{PO}_{4}$ to the bay than groundwater. When compared to ocean mixing, groundwater contributes significantly more DIC and $\mathrm{Si}$ to Tomales Bay but less, in terms of net nutrient flux, of $\mathrm{PO}_{4}, \mathrm{NH}_{4}$, and $\mathrm{NO}_{3}$. These results indicate that groundwater plays an important role in nutrient and freshwater loading to Tomales Bay, especially during the dry, summer months. 


\section{INTRODUCTION}

Although surface water, rainfall, ocean advection, ocean mixing, and bottom sediments have been considered the major contributing sources of nutrients to lakes and bays, recent studies have shown that groundwater may also be a significant contributor (Loeb and Goldman, 1979; Brock et al., 1982; Capone and Bautista, 1985; Bokuniewicz, 1980; Lee, 1977). Unlike surface water, which discharges into the lake or bay at discrete points, groundwater seepage occurs over the total length of the shoreline and at a much lower velocity. This increases the potential impact on the lake or bay in terms of nutrient loading and eutrophication (Loeb and Goldman, 1979). Loeb and Goldman (1979) found that groundwater from the Ward Creek watershed, California, contributes $49 \%$ of the total nitrate-nitrogen loads and $40 \%$ of the total phosphorus loads to Lake Tahoe. The groundwater discharge of freshwater was calculated to be $16 \%$ of the creek flow and $10 \%$ of the total precipitation in the watershed.

Brock et al. (1982) found in their study of Lake Mendota, Wisconsin that groundwater seepage accounts for approximately $30 \%$ of the water budget to the lake and contributed $12 \%$ of the total phosphorus and $2 \%$ of the total nitrogen budgets. In this case, groundwater played a minor role in nutrient loading but a greater role in contributing water to the lake. Brock et al. (1982) also claimed that seepage inflow, assumed to be chemically equivalent to the sediment pore water lying just below the sediment-water interface, was considerably lower in nitrogen and phosphorus than surface inflow but is higher in phosphorus and lower in nitrogen than well water. 
In terms of well phosphorus concentrations, this conciusion is highly unlikely. Phosphorus has a strong tendency toward adsorption to soil particles and thus one would expect the concentration of phosphorus in seepage waters to be less than that in well waters. Nitrate does not tend to adsorb and therefore its well water concentration should vary little until the groundwater reaches the biologically active zone at the lake's sediment-water interface. There the process of denitrification could alter the concentration of nitrogen in the seepage water.

Studies by Capone and Bautista (1985) and Bokuniewicz (1980) on the Great South Bay, Long Island, New York also estimated groundwater nutrient and freshwater loading to bays. Bokuniewicz (1980) estimated that groundwater contributes $10-20 \%$ of the total freshwater to the bay. Capone and Bautista (1985) concluded that groundwater should be viewed as an important source of nitrates to the Great South Bay due to the high concentrations of nitrates found in the groundwater of Long Island.

\section{Tomales Bay}

An analysis of the biogeochemical pathways and nutrient dynamics in Tomales Bay, Western Marin County, California (figure 1) is being conducted by Smith et al. (1987). Smith's proposed hypothesis is:

The net organic production of marine ecosystems with restricted water exchange is limited by the availability of phosphorous rather than nitrogen as is more commonly supposed for coastal marine ecosystems (Smith et al., 1987).

This hypothesis is based on studies in tropical and subtropical oligotrophic systems. Tomales Bay was chosen by Smith et al. (1987) to 


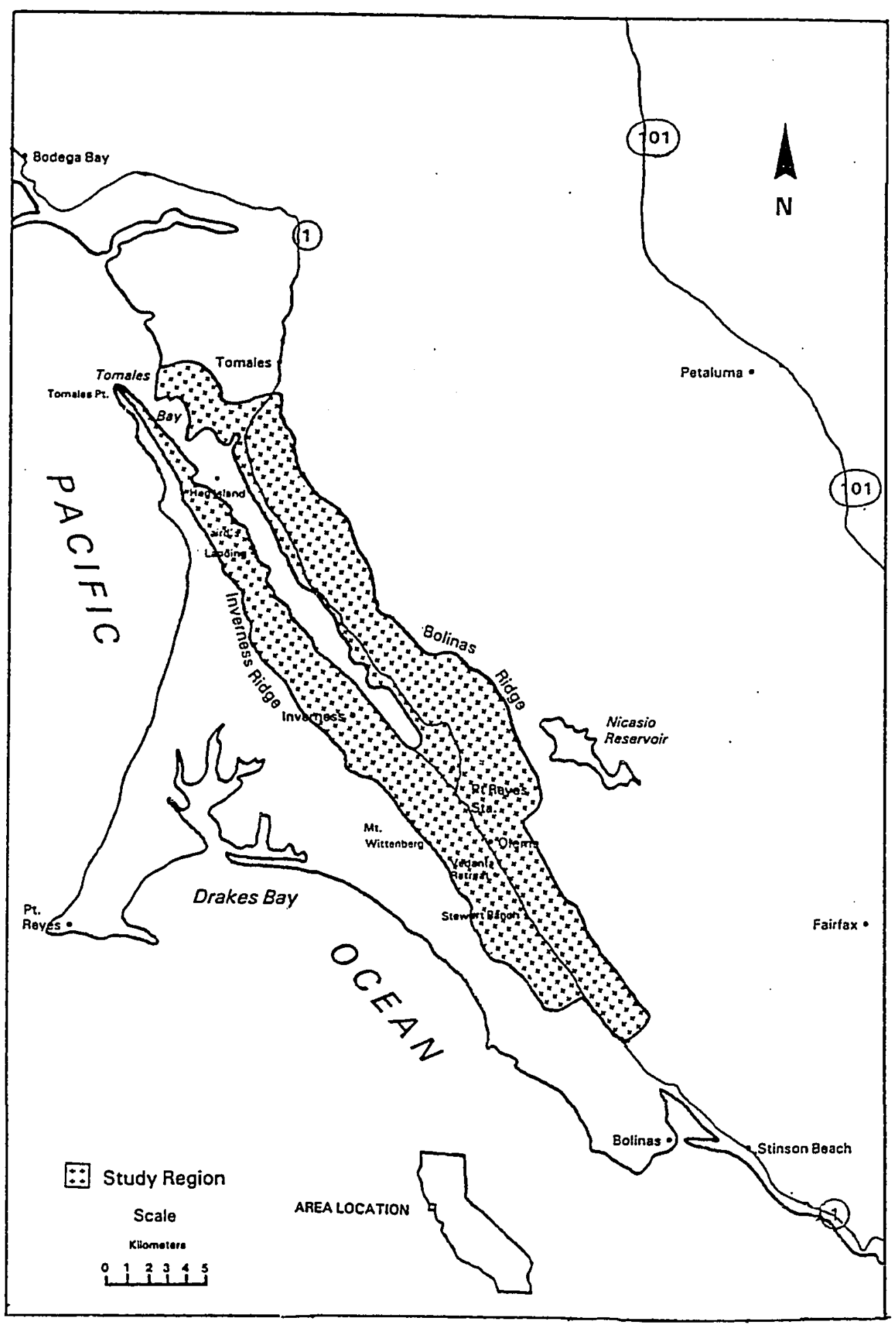

Figure 1. Location Map. 
extend the hypothesis into temperate coastal ecosystems. Smith et al. (1987) claim that, because Tomales Bay receives more dissolved and particulate terrigenous input than the sites previously examined and also derives material from coastal upwelling, this intended hypothesis is rendered untestable for Tomales Bay. Smith et al. (1987) believe, however, "important conclusions will be derived about ecosystem-scale nutrient dynamics and biogeochemical pathways in the bay." Nutrient flux rates were calculated from June, 1987 to March, 1988 for streams and during the late summer of 1985, for ocean advection and mixing as well. Because groundwater was not included by Smith et al. (1987) and groundwater discharges potentially play an important role, it is the intention of this thesis to assess the groundwater nutrient and freshwater loading to Tomales Bay.

\section{Thesis Objectives}

The objectives of this thesis are to:

1) quantify the groundwater nutrient concentrations by sampling wells and springs in the Tomales Bay watershed;

2) quantify the groundwater contribution to Tomales Bay by a water budget analysis and by a Darcy's Law analysis of the hydraulic parameters in the Tomales Bay watershed; and

3) assess the significance of the groundwater nutrient and freshwater loading to Tomales Bay in comparison to other pathways. 
The pathways being considered for this study are streams, rainfall, ocean advection, and ocean mixing. The two major streams are Lagunitas Creek at the southern end of the bay and Walker Creek at the northern end. Rainfall is taken as the average rainfall of three stations located at the northern and southern boundaries of Tomales Bay. Ocean advection is the process by which nutrients are exchanged in the system by advective inflow in response to water depletion in the bay (by high evaporation) or advective outflow in response to excess water in the bay from freshwater inputs. Ocean mixing is the process by which nutrients are exchanged in the system by wind, tide, and current induced mixing.

\section{Previous Studies}

In addition to the previously mentioned nutrient budget studies, hydrogeologic, and geologic studies have been done on the Tomales Bay watershed. The conclusions from these studies are that no major aquifer system exists in the watershed and that groundwater is extremely limited. It is especially limited in the weathered and fractured zones of the eastern Bolinas Ridge and the western Inverness Ridge. Some potential for groundwater development, with well yields up to $3.8 \mathrm{l} / \mathrm{s}$ (60 gpm), exists in the alluvial fill of the San Andreas fault zone at the bay's south end and the alluvial fan and valley deposits along the east and west shores. Although no major aquifer systems exist in the watershed, groundwater may still play a role in nutrient and freshwater loading of Tomales Bay. The hydrogeologic studies are by Dale and Rantz (1966), North Marin County Water District (1967), (1969), and (1987), California Department of Water Resources (1978), Cooper and Clark (1978), Collier (1983), Mazzella 
(1983), and Lewis (1983), The geologic studies are by Galloway (1977), Hall and Hughes (1980), Daetywyler (1966), Wahrhaftig and Wagner (1972), and Wagner (1977). 


\section{GEOGRAPHIC AND GEOLOGIC SETTING}

\section{Location}

The study area is the region surrounding Tomales Bay in Western Marin County, California (figure 1). The bay is approximately 20 kilometers long, measured from the south end of the bay to Sand Point in the north, and averages approximately 1.4 kilometers wide. The San Andreas fault, a right lateral, northwest-trending transform fault, bisects the bay. The bay was formed during the Holccene sealevel transgression when ocean waters flooded this portion of the San Andreas rift zone (Daetwyler, 1966).

\section{Structural Setting}

The Tomales Bay region is structurally dominated by the San Andreas fault system. The right lateral transiorm fault trends northwest through the region, forming the subaerial San Andreas fault trough. The fault separates the granitic basement rock on the west from the Franciscan Assemblage basement rock on the east (Plate 1). The present Tomales Bay and Bolinas Lagoon are the portions of the San Andreas trough that were flooded during the Holocene transgression of ocean water. Evidence of strike-slip faulting such as scarps, slice ridges, sag ponds, shutter ridges, and offset streams is found along the San Andreas fault (Galloway, 1977). The last movement along the fault in this region was in 1906. The maximum right lateral displacement in the Tomales Bay region during the 1906 event was on the order of $4.8 \mathrm{~m}$ (16 ft) (Galloway, 1977). 


\section{Recent Geologic History}

The recent geologic history of the Tomales Bay region is best presented by Daetwyler (1966) in his study "The Marine Geology of Tomales Bay." The study describes the formation of the San Andreas fault trough and the ensuing formation of Tomales Bay. He divides the recent geologic histery of the Tomales Bay region into four phases: pre-trangressive phase, initial rapid transgression, first cycle mud deposition, and second cycle mud deposition (Daetwyler, 1966).

Pre-transgressive Stage

The pre-transgressive subaerial rift stage as Daetwyler explains, occurred before the eustatic sealevel rise. The subaerial rift valley was similar to the one that exists south of Tomales Bay. The characteristics of the rift valley were a discontinuous center ridge, sag ponds, and offset stream channels. Daetwyler believes the drainage system of the southern bay (Lagunitas Creek) merged with the northern system (Walker Creek) and exited to the Pacific Ocean through a gap in the ridge that connects Tomales Point to Bodega Head (figure 2). In addition, Daetwyler states that Huy Island, Tom's Point, Tomasini Point, and Millerton Point are ail expressions of this now submerged discontinuous ridge (Daetwyler, 1966).

\section{Initial Rapid Transgression}

Based on sonoprobing of the bayfloor Daetwyler interprets that the rise in sealevel quickly flooded the rift valley and a basal transgressive facies was deposited locally over the pre-transgressive surface. Estuarine conditions existed south of the present day Pt. Reyes Station. Sand was being transported south from Bodega Bay and "both Lagunitas 


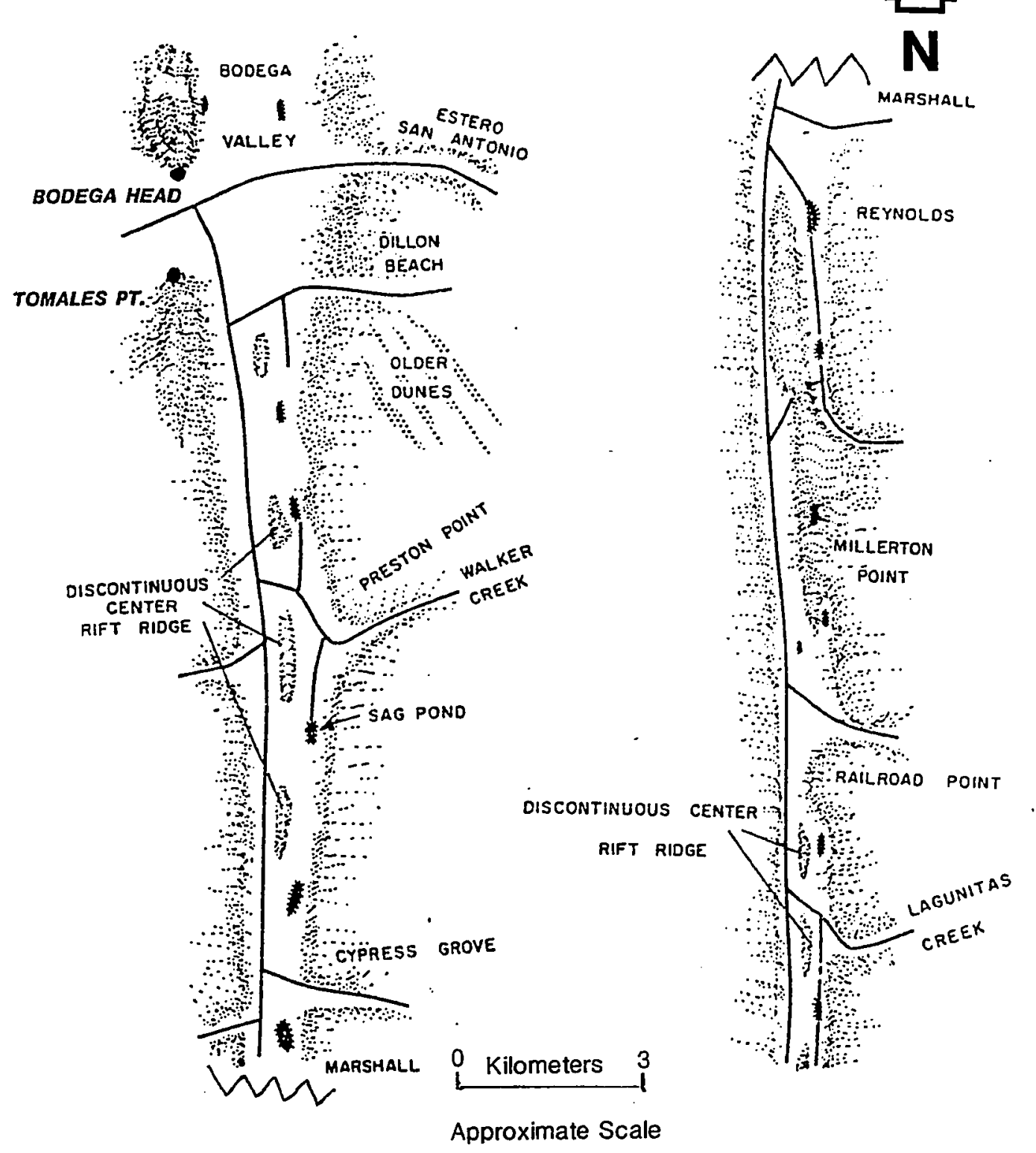

Figure 2. Schematic paleogeography; pre-transgressive subaerial rift valley (Daetwyler, 1966). 
Creek and Walker Creek were supplying sediment for deposition." Tom's Point and Hog Island were then islands in the center of the bay (Daetwyler, 1966) (figure 3).

First Cycle Mud Deposition

Sand carried by longshore drift from Bodega Bay was deposited on the northern bayfloor. The sand was deposited as far south as a topographically high rock outcrop southeast of Hog Island. The rock outcrop acted as a barrier against longshore drift, forming a sand spit which separated the bay into a northern segment dominated by sand deposition and a southern segment dominated by finer sediment deposition. The main tidal channel existed along the west side of the sand spit.

Sand transport from Bodega Bay eventually deposited enough material near the entrance of Tomales Bay (Dillon Beach) to effectively cut off the sand supply to the more southerly spit. This southerly sand spit was then transgressed by the still rising sea (figure 4). When this occurred, the present depositional processes of mud deposition south of Sand Point and sand deposition north of Sand Point, became dominant (figure 5) (Daetwyler, 1966).

\section{Second Cycle Mud Deposition}

The second cycle mud deposition occurred after the southern spit was transgressed (figure 5). Fine grained sediments from the southern drainages were deposited in relict tidal channels and on top of the older bay muds. The second cycle mud deposition is occurring today as more fine sediments are being deposited on the southern two-thirds of the Tomales Bayfloor. Approximately 3 meters of younger muds cover the bayfloor with 


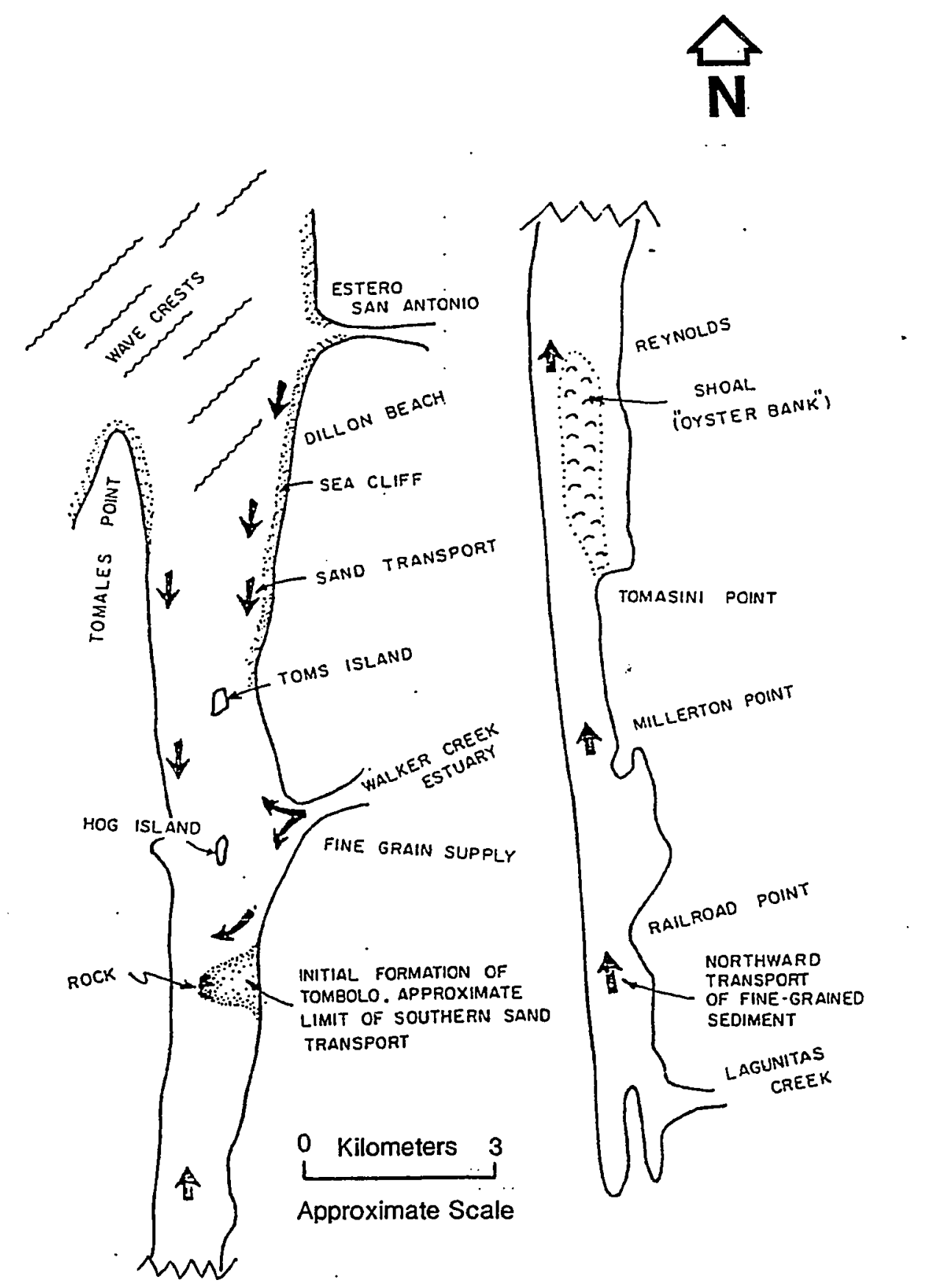

Figure 3. Schematic paleogeography; initial transgression, first cycle mud deposition (Daetwyler, 1966). 


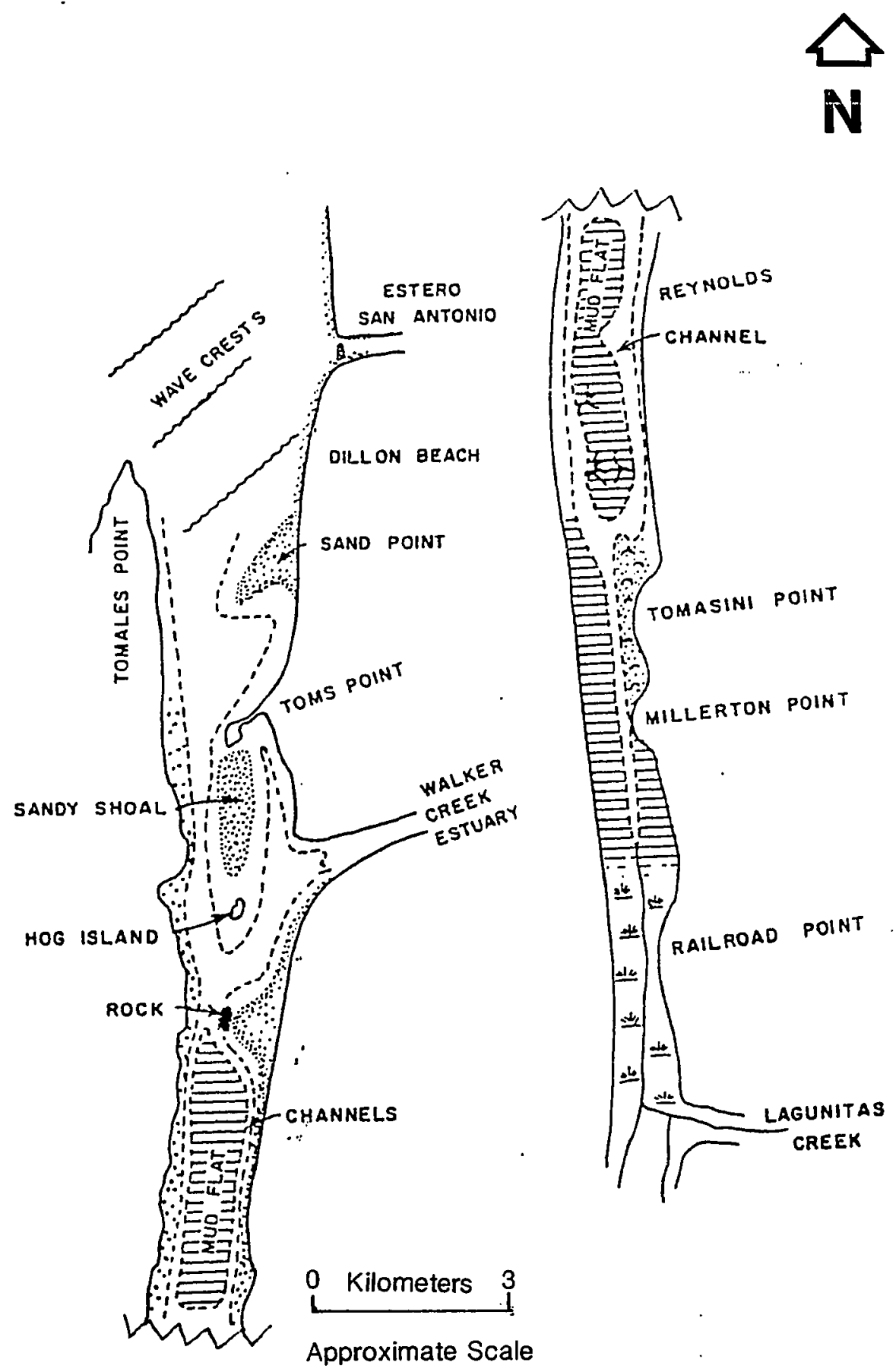

Figure 4. Schematic paleogeography; end of first cycle mud deposition (Daetwyler, 1966). 


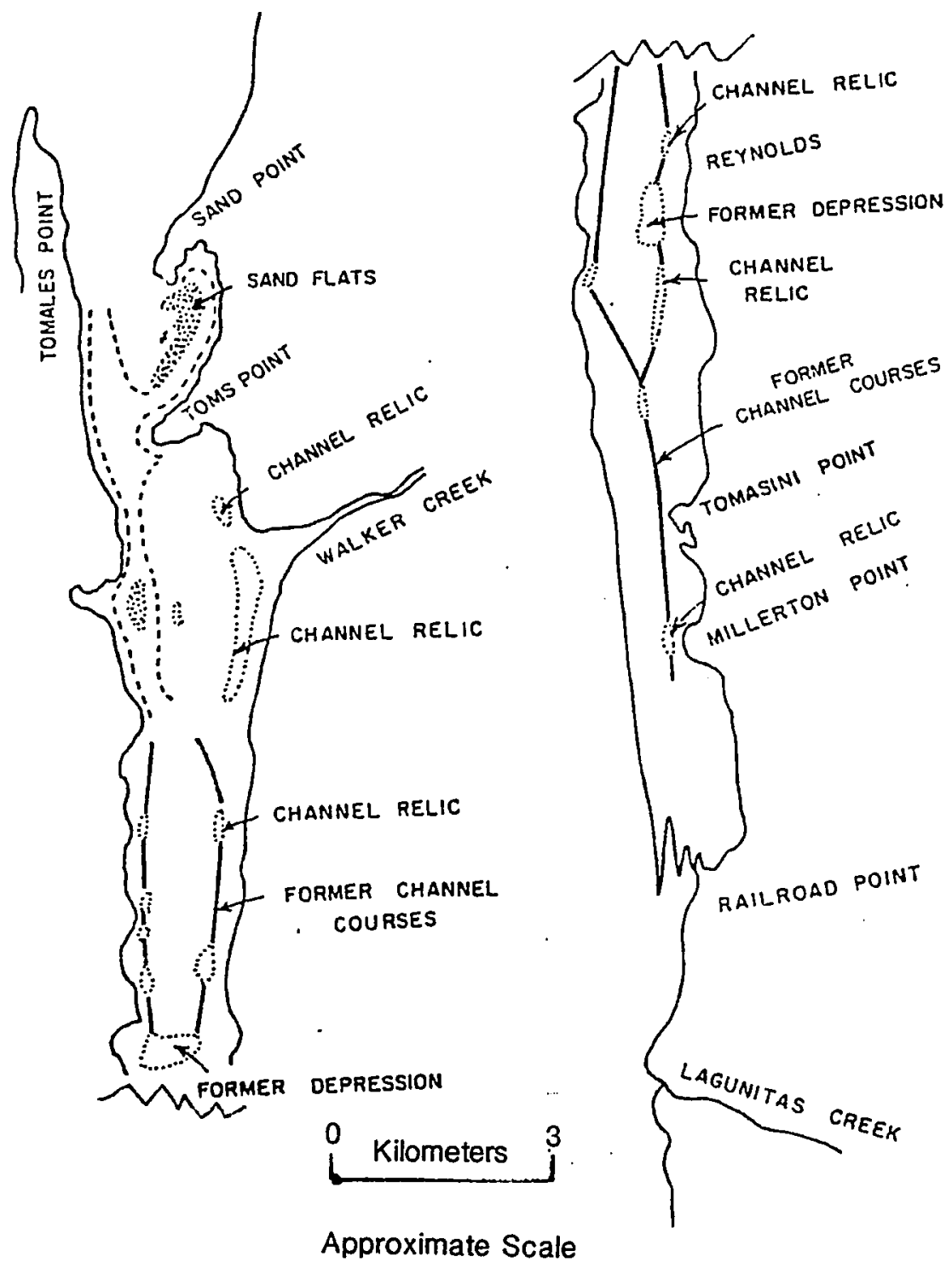

Figure 5. Schematic paleogeography; second cycle mud depostion. Location of relict bathymetric features in Tomales Bay, 1860 (Daetwyler, 1966). 
thicker sequences in the old channels. Daetwyler's investigation did not reveal the thickness of the older bay muds (Daetwyler, 1966).

\section{Geology}

The geology of the Tomales Bay region is extremely complex due to plate movement along the San Andreas fault. The right lateral strike-slip motion along the fault has juxtaposed two different rock types, the granitic rocks west of the fault and the Franciscan Complex east of the fault (Galloway, 1977). Monterey Shale and small amounts of Laird Sandstone overlie the granitic rocks south of Mt. Wittenberg. The Millerton Formation, beds of clay, silt, sand, and gravel, forms headlands along the east shore of the bay. Quaternary alluvium, terrace deposits, and the Olema Creek Formation are present in the San Andreas trough south of Tomales Bay (Plate 1) (Galloway, 1977).

The Tomales Bay study region has been divided into three sampling regions differentiated by geologic and hydrologic charactersitics. The well and spring sampling study areas are delineated as follows: Study Area I encompassess the granite of the Inverness Ridge; Study Area II encompasses the Franciscan Assemblage of the Bolinas Ridge; and Study Area III encompasses the alluvium in the San Andreas trough (figure 6).

Study Area I - The Inverness Ridge

Granitic Rocks. The granitic rocks, forming the backbone of the Inverness Ridge, are believed to be approximately 80 million years old and have moved from the south 160 kilometers (100 miles) or more along the San Andreas fault (Galloway, 1977). The granite is fractured and 


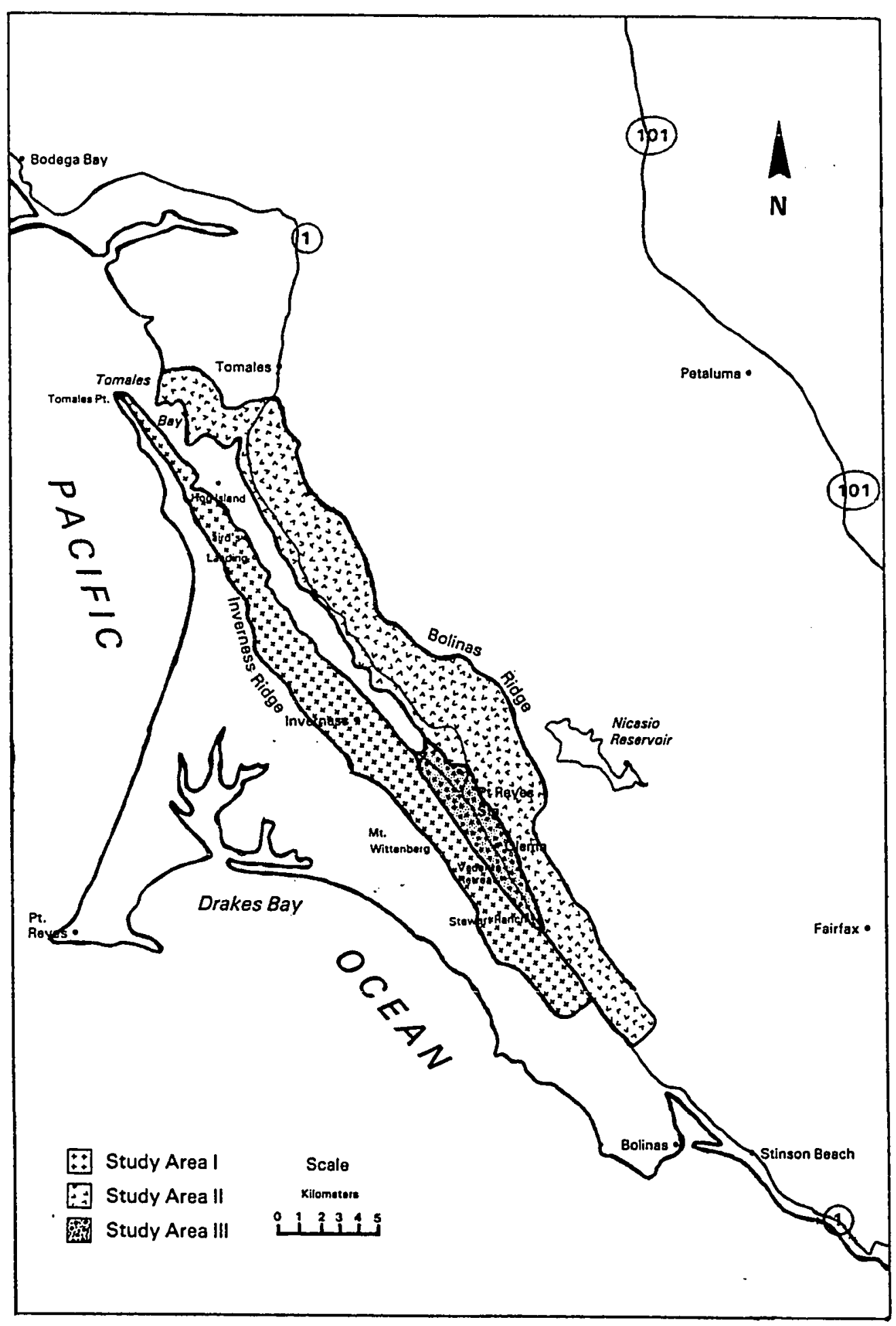

Figure 6. Study Area map 
faulted (Wahrhaftig and Wagner, 1972). Weathering has been dominant on the Inverness Ridge, creating thicknesses of decomposed granite of up to 30 meters (100 ft) on the ridge tops and less than 18 meters (60 ft) along the slopes (California Department of Water Resources, 1978). Some metamorphic inclusions, schist and limestone (marble), are found within the granite and considered to be the oldest rocks in the region (Galloway, 1977). Although the term "granite" is used to describe these rocks, Galloway (1977) believes the plutonic body actually ranges in composition from quartz diorite through granodiorite to ademellite.

Monterey Shale. The Monterey Shale is present in the study area along the Inverness Ridge from Mt. Wittenberg south and includes chert, porcelanite, organic shale, and thin hard sandstone (Galloway, 1977). The Monterey Shale was deposited during the Miocene Age and lies conformably on the Laird Sandstone (Galloway, 1977).

Laird Sandstone. Laird Sandstone is present in the study area along the Inverness Ridge, between Laird's Landing and Heart's Desire Beach and near Mt. Wittenberg in the south. The sandstone is a massive, medium to coarse grained, fairly friable with little cementation. The thickness is generally believed to be between $30-60$ meters (100-200 $\mathrm{ft}$ ) and the age estimated to be Miocene (Galloway, 1977).

Alluvium. Alluvium is present in the larger valleys that cut into the Inverness Ridge. Alluvial fans were deposited at the mouths of these larger valleys during the last ice age when sea level was much lower and Tomales Bay was subaerially exposed (Daetwyler, 1966). Wahrhaftig and Wagner (1972) found that the alluvium deposited in the valleys of the granitic 
Inverness Ridge consisted largely of medium to coarse sand with scattered granules and pebbles.

The alluvial fans consisted of similar material and were believed to extend significantly out into Tomales Bay, possibly merging with fans from the east side of the bay (Daetwyler, 1966).

Study Area II - The Bolinas Ridge

Franciscan Complex. Rocks associated with the Franciscan Complex cover most of the study area east of Tomales Bay and west of the Bolinas Ridge. Franciscan rocks in the study area can be divided into two groups: sheared (melange) and unsheared rocks. Franciscan Melange is the dominant rock on the east side of the bay. The sheared sandstone and shale show no evidence of their sedimentary structure and have been crushed by tectonic forces. Some Franciscan Melange in the study area contains blocks of graywacke, serpentine, greenstone, chert, and schist (Wahrhaftig and Wagner, 1972).

Millerton Formation. The Millerton Formation consists of marine and nonmarine sand and gravel interbedded in a silty-clay matrix. The sand and gravel are present on three points along the eastern shore of Tomales Bay and were deposited during the Pleistocene Era in an inlet similar to Tomales Bay. The formation is generally less than 18 meters (60 ft) thick and contains numerous fossils (Galloway, 1977). It is believed that the Millerton Formation correlates with the Olema Creek Formation 11 kilometers (7 miles) to the south (Galloway, 1977). 
Merced Formation. A small exposure of the Merced Formation is present in the northeast corner of the Tomales Bay watershed (Galloway, 1977). This section of the Merced Formation overlies the Franciscan and is composed of soft, yellowing marine sand and mud (Wahrhaftig and Wagner, 1972). Wahrhaftig and Wagner (1972) state that the nearly flat lying formation was deposited approximately 5 million years ago and subsequently uplifted and eroded, leaving only hilltop remnants.

Alluvium. Minor amounts of alluvial sand and gravel are present in the valleys of the Bolinas Ridge and along Walker Creek.

\section{Study Area III - The San Andreas Trough}

Alluvium. Alluvial sand and gravel underlie much of the San Andreas trough south of Tomales Bay. The medial ridges that are located in the San Andreas fault trough are composed of older alluvial deposits that were squeezed up along the fault (Wahrhaftig and Wagner, 1972). Hall and Hughes (1980) noted that the multitude of Quaternary deposits and surfaces in the San Andreas trough indicates that several periods of erosion and deposition occurred during historic fluctuations in sea level. In addition, most of the alluvium in the medial ridges originated from the granitic rock and Monterey Formation on the west side of the San Andreas fault (Hall and Hughes, 1980).

Stream Terrace Deposits. Stream terrace deposits, composed of poorly sorted and unconsolidated gravel, are found throughout the San Andreas trough (Galloway, 1977). Most notably the town of Pt. Reyes Station is situated upon one large area of stream terrace deposits. 
Olema Creek Formation. The Olema Creek Formation occurs approximately 6.4 kilometers (4 miles) south of Pt Reyes Station in the San Andreas trough. It consists predominantly of light blue-gray, clayey siltstone or claystone, thinly laminated, with interbeds of coarse granitic gravel (Galloway, 1977). Wells drilled in the Pt. Reyes Station area have encountered materials similar to the Olema Creek Formation beneath the overlying terrace materials. Galloway (1977) believes the the Olema Creek Formation correlates with the Millerton Formation 11 kilometers ( 7 miles) to the north.

Minor Formations. Minor amounts of the Franciscan and the Merced Formation are present in the trough, mostly south of Vedanta Retreat. The characteristics of these formations have previously been discussed. 


\section{HYDROGEOLOGY - GROUNDWATER OCCURRENCE}

Potable groundwater is limited in the Tomales Bay watershed. The geological materials are the main factors limiting this resource; the granite of the west bay and the Franciscan Formation of the east bay have poor aquifer characteristics. The alluvium in the valleys of the east and west bay and the San Andreas trough, the terrace deposits, and the Millerton Formation are more productive water sources but not on a scale that is considered adequate by the region's water districts. The following is a summary of the groundwater occurrence in each study area of the Tomales Bay watershed.

\section{Study Area I - The Inverness Ridge}

Study Area I is predominantly composed of granitic rock with some overlying Monterey Shale and Laird Sandstone. Alluvium is present in the valleys, and alluvial fans are present at the mouths of the major streams. Limited groundwater potential, up to $0.63 \mathrm{l} / \mathrm{s}(10 \mathrm{gpm})$, is found in the decomposed granite and in the small fracture openings in the granite (Dale and Rantz, 1966). Numerous springs exist in the landslide material along the slopes of the Inverness Ridge. A greater groundwater potential exists in the alluvium and alluvial fans. Well yields in the sand and gravel of these formations are up to approximately $3.8 \mathrm{l} / \mathrm{s}(60 \mathrm{gpm})$ (Dale and Rantz, 1966). Groundwater flow in the Inverness Ridge generally follows the topography and eventually discharges into Tomales Bay. A median water depth of $15 \mathrm{~m}(50 \mathrm{ft})$ is found at the ridge tops and a median water depth of $2.2 \mathrm{~m}(7 \mathrm{ft})$ is found at the base of the ridge (California Department of 
Water Resources, 1978). The groundwater levels generally mimic the topography but in a subdued manner (California Department of Water Resources, 1978).

\section{Study Area II - The Bolinas Ridge}

The North Marin County Water District (1967) study of the east shore of Tomales Bay revealed that the groundwater potential of the Franciscan Complex is negligible. Some wells were drilled in the weathered and fractured Franciscan Complex but produced only enough for domestic purposes, up to $0.63 \mathrm{l} / \mathrm{s}(10 \mathrm{gpm})$. Few wells exist in the east bay area. The most productive wells are located in the hillsides near Blake's Landing and along the bayshore of Tomales Bay. The Marconi property, south of Blake's Landing, also has a productive hillside well. The North Marin County Water District (1967) believes that groundwater in any quantities greater than $0.63 \mathrm{l} / \mathrm{s}(10 \mathrm{gpm})$ would be found in pockets of alluvium along Walker Creek and in the sand and gravel of the Millerton Formation.

\section{Study Area III - The San Andreas Trough}

Right lateral fault movement makes it difficult to assess the hydrogeology of the San Andreas trough. A well drilled 509 meters (1670 ft) deep near Olema encountered 32.2 meters (106 ft) of alluvium, 273 meters (895 ft.) of fault gouge and sheared Franciscan rock and passed into less sheared Franciscan rock at 305 meters (1000 ft) (California Department of Water Resources, 1978). When compared to the east and west sides of the Tomales Bay watershed, Study Area III has more potential for groundwater because of its alluvial nature and the greater rate of precipitation there. 
Wells drilled in the vicinity of $\mathrm{Pt}$. Reyes Station have penetrated productive sands and gravel. In addition, lenses of stream terrace gravel exist along Lagunitas Creek and near Pt. Reyes Station (North Marin County Water District, 1988). The hydraulic conductivities of this gravel, obtained from three pump tests, have been found to be 114 meters/day ( $375 \mathrm{ft} / \mathrm{d}$ ) or more (North Marin County Water District, 1987). A well drilled at the Olema Valley Ranch Campground yielded 4.7 1/s (74 gpm) with very little drawdown (California Department of Water Resources, 1978).

In general, the California Department of Water Resources (1978) believes that a great potential for groundwater exists north of Lagunitas Creek and claims that wells could produce up to $16 \mathrm{l} / \mathrm{s}(250 \mathrm{gpm})$ and average $5 \mathrm{l} / \mathrm{s}(79 \mathrm{gpm})$. In the region south of Lagunitas Creek, the older alluvium should yield up to $6.3 \mathrm{l} / \mathrm{s}(100 \mathrm{gpm})$ (California Department of Water Resources, 1978). 


\section{SURFACE WATER HYDROLOGY}

\section{Major Streams}

Three major streams flow through the Tomales Bay watershed: Lagunitas Creek, Olema Creek, and Walker Creek (figure 7). The total watershed areas for each creek are as follows: Lagunitas Creek, ungaged $30 \mathrm{Km}^{2}$, gaged $212 \mathrm{Km}^{2}$; Olema Creek, $37 \mathrm{Km}^{2}$; Walker Creek, ungaged

$109 \mathrm{Km}^{2}$, gaged $81 \mathrm{Km}^{2}$ (Stephen Smith, unpublished data). Monthly flow rates can be found in Table 1. One interesting note concerns the drainage patterns of streams in the San Andreas trough. For nearly 3.2 kilometers (2 miles), Pine Gulch Creek and Olema Creek flow at nearly the same elevation on parallel courses but in opposite directions (Galloway, 1977).

\section{Minor Streams}

Numerous minor streams have eroded valleys through the Inverness Ridge and the Bolinas Ridge to Tomales Bay or to larger streams. First Valley Creek, Second Valley Creek, and Third Valley Creek are located on the Inverness Ridge. Millerton Creek flows down the Bolinas Ridge. All mentioned streams empty into Tomales Bay. The total drainage area of these minor streams in the Tomales Bay watershed is approximately 90 $\mathrm{Km}^{2}$ (Stephen Smith, unpublished data). 


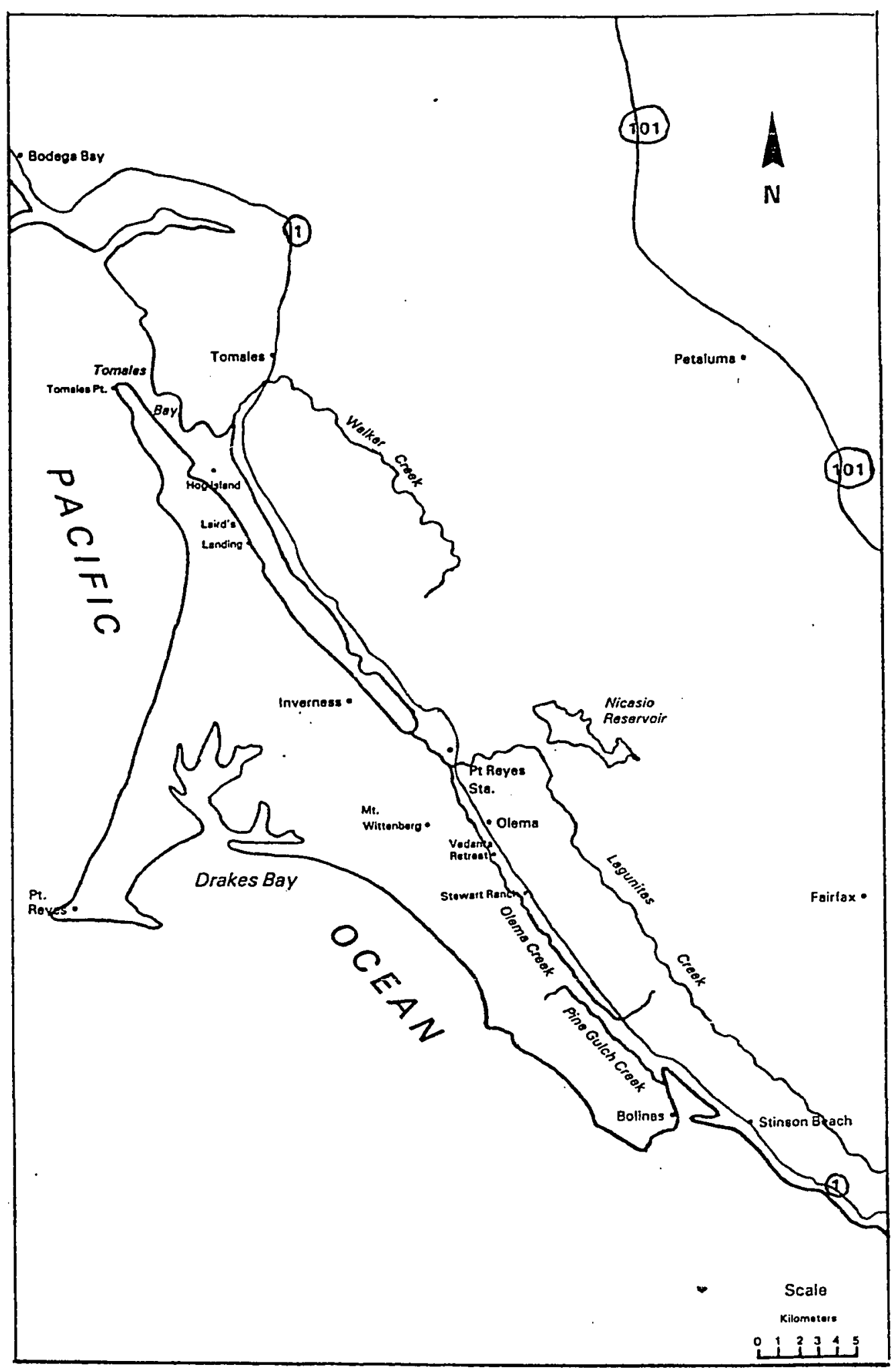

Figure 7. Major Streams in the Tomales Bay watershed. 
Table 1. Average flow rates for Lagunitas Creek, Walker Creek, and additional surface water (minor creeks and Olema Creek), taken from USGS stream gage data, October, 1974 to 1987 for Lagunitas Creek and October, 1968 to 1987 for Walker Creek (Ken Markham, US Geological Survey, Santa Rosa, personal communication with Stephen Smith, 1987).

$\begin{array}{lrrr} & \begin{array}{r}\text { Lagunitas } \\ \text { Creek } \\ 10^{3} \mathrm{~m}^{3}\end{array} & \begin{array}{r}\text { Walker } \\ \text { Creek } \\ 10^{3} \mathrm{~m}^{3}\end{array} & \begin{array}{r}\text { Additional } \\ \text { Surface Water } \\ 10^{3} \mathrm{~m}^{3}\end{array} \\ \text { Month } & & & \\ \text { JAN. } & 24,439 & 28,002 & 11,359 \\ \text { FEB. } & 34,365 & 23,661 & 11,945 \\ \text { MAR. } & 28,722 & 15,878 & 8,985 \\ \text { APR. } & 8,218 & 4,646 & 2,597 \\ \text { MAY } & 1,568 & 739 & 458 \\ \text { JUN. } & 537 & 360 & 184 \\ \text { JUL. } & 405 & 355 & 160 \\ \text { AUG. } & 368 & 326 & 147 \\ \text { SEP. } & 344 & 331 & 144 \\ \text { OCT. } & 573 & 366 & 192 \\ \text { NO:. } & 5,099 & 4,362 & 1,990 \\ \text { DEC. } & 12,585 & 14,951 & 5,985 \\ \text { Total } & & & \\ & 117,223 & 93,977 & 44,146\end{array}$




\section{LAND USE}

The region surrounding Tomales Bay is predominantly rural, with a population of approximately 3000 (Smith et al., 1985). Dairy farms, cattle grazing, and horse stables are dominant in the San Andreas trough and along the east side of the bay. Since animal wastes are generally rich in nitrates, ammonium, and phosphates, the existence of these farms and stables may increase the concentrations of nutrients in the groundwater and surface water. In addition to the dairy farms on the east side of the bay, numerous oyster companies exist along the bayshore, attesting to the relatively pristine waters in Tomales Bay today. Much of the western shore of Tomales Bay and the Inverness Ridge is parkland. Residential development is along the eastern bayshore, western bayshore, the Inverness Ridge, and Pt. Reyes Station.

\section{Water Supply}

The Tomales Bay Region's water needs are served by the North Marin County Water District, the Inverness Public Utility District, numerous small mutual water systems, and private wells and springs. Inverness Park and Pt. Reyes Station are served by the North Marin County Water District, while Inverness is served by the Inverness Public Utility District.

\section{Domestic Wastes}

In the Tomales Bay watershed, domestic wastes are exclusively handled by septic tank systems. No sewage treatment plants exist in the Tomales Bay watershed. A study done by Cooper and Clark (1978) 
on the impact of septic tank disposal systems in the Inverness area concluded that septic systems could have an adverse effect on groundwater quality, if the tanks were located on steep slopes, near streams (because of high water tables), or near fractured granite, which allows unfiltered effluent to reach the groundwater. Septic tank effluent contains high concentrations of nitrates, ammonium, and phosphates, and thus may be a potential source of nutrients for the groundwater and Tomales Bay. 


\section{STUDY METHODS}

The two major tasks of this thesis were to:

1) establish groundwater quality (nutrient concentrations) by sampling wells and analyzing data; and

2) estimate a groundwater discharge rate to Tomales Bay by compiling and analyzing existing data on groundwater occurrence.

The following section explains the methods used in accomplishing these tasks.

\section{Well Water Sampling Procedure}

To assess the nutrient content of the groundwater surrounding the Tomales Bay region, well sampling was performed. Water samples were taken from 51 geographically distributed wells throughout the Tomales Bay watershed (Plate 2). The distribution of sampled wells provides an adequate representation of water quality for each study area. Wells were selected on the basis of their location and sample availability. The sampled wells were chosen to be within the Tomales Bay watershed and representative of the water quality for each study area. In order to obtain an adequate representation of the study area water quality, sampled well locations ranged from the ridge and slope areas down to the bay margin. Fifteen wells were resampled to assess any changes in nutrient contents over time. The sampling period was from June, 1987 to March, 1988 to include observations on variability in nutrient concentrations hetween 
summer and winter samples. Two replicate samples were taken to evaluate errors in sampling.

Water was pumped from each well using the available pumping system and was allowed to flush for 5 minutes before a sample was taken. At sites 29 and 18, samples were taken directly out of the system by lowering a plastic bucket down the well at site 29 and in a holding tank at site 18.

The water samples were immediately filtered with a glass fiber filter to remove suspended particulates and collected in acid washed plastic bottles to reduce the possibility of contamination. Two samples of water for nutrient analysis were taken at each well. One sample was frozen and analyzed for its phosphate, nitrate-nitrite, and ammonium content. The other sample was refrigerated and analyzed for its silica content.

\section{Water Quality Analytical Procedure}

Field Analytical Techniques

Field analyses were immediately performed on sample water to determine its temperature, $\mathrm{pH}$, alkalinity, and conductivity. $\mathrm{pH}$ was measured with a Hach field $\mathrm{pH}$ meter, temperature was measured in a sampling bucket with a thermometer, total alkalinity was measured by sulfuric acid titration with a Hach digital titrator, and conductivity was measured by a Hach DRL-5 conductivity meter.

\section{Laboratory Analytical Techniques}

The frozen and refrigerated samples were analyzed by the Hawaii Institute of Marine Biology Analytical Servicis Group (Univeristy of Hawaii). Automated analysis procedures follow the analytical procedures outlined in 
Smith et al. (1981) as modified by the University of Hawaii Analytical Services Laboratory. In order to calculate dissolved inorganic carbon (DIC) concentrations for each well, $\mathrm{pH}$, alkalinity, and temperature values were used. The method and equations used are presented in Skirrow, (1975). A computer program utilizing this method takes the $\mathrm{pH}$, alkalinity and temperature values and calculates the DIC value. The DIC computer calculations were performed by Dr. Stephen Smith of the University of Hawaii.

\section{Statistical Analysis of Nutrient Data}

Initially, for each nutrient, the replicate samples were averaged, then those locations with multiple sampling were averaged to arrive at a single yalue for each location. The mean and standard deviation for each study area were then calculated. Any sample locations whose values were outside two standard deviations from the mean, approximately $5 \%$, were eliminated. This was done in order to eliminate the bias toward these unusually high values. Unusually low values were not encountered outside of two standard deviations from the mean. All of the data outside of two standard deviations exhibited very high concentrations and were generally located near probable sources of contamination. In general they were not areally typical and insignificant on a regional scale. The mean and standard deviation were then recalcutated and the final results obtained.

\section{Quantification of Groundwater}

\section{Soil Moisture Budget Method}

The soil moisture budget method to quantify the volume of the groundwater contribution to the bay uses precipitation, runoff, 
evapotranspiration, soil depth, and soil water capacity to calculate groundwater recharge for an average year. The amount recharged is assumed to equal the amount discharged to the bay. Figure 8 is a pictoral representation of the input and output variables used in the soil moisture budget method.

Modified Study Areas

In order to obtain accurate discharge rates for the water budget method, the study areas used for the nutrient analysis had to be modified (figure 9) because water recharged into the southern ends of the Bolinas and Inverness Ridges would flow into the trough area before discharging into the bay. They were modified so all water discharge at each seepage area, the southern, western and eastern shorelines, would have originated within that study area.

\section{Generalized Soils Map}

Soil maps and soil descriptions from the United States Department of Agriculture's (USDA) (1985) "Soil Survey of Marin County, California" were used to create a generalized soils map for the Tomales Bay watershed. Specific soils were delineated on the USDA survey maps and coded by number. Similar specific variants of soil series were grouped by the USDA survey into generalized soils based on underlying geology, relief, and drainage. Eight generalized soils, each consisting of up to three specific soils, were mapped on mylar over the original more detailed specific soil maps (Plate 3). A description of each soil is in Appendix A. The area for each generalized soil was measured within each study area using on Alvin No. PL655 planimeter. Two planimeter measurements were made of each 


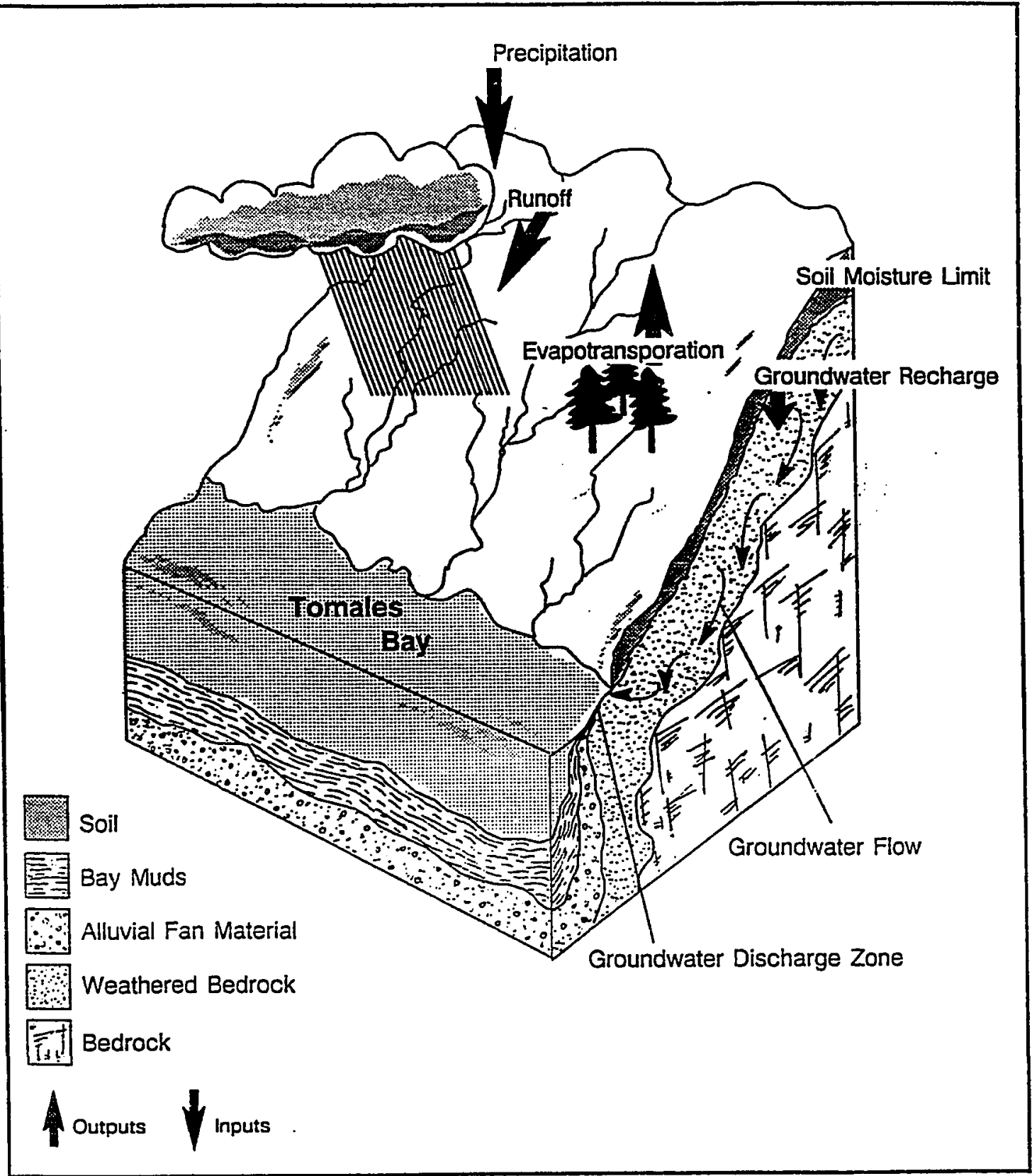

Figure 8. Input and output variables for the soil moisture budget method. 


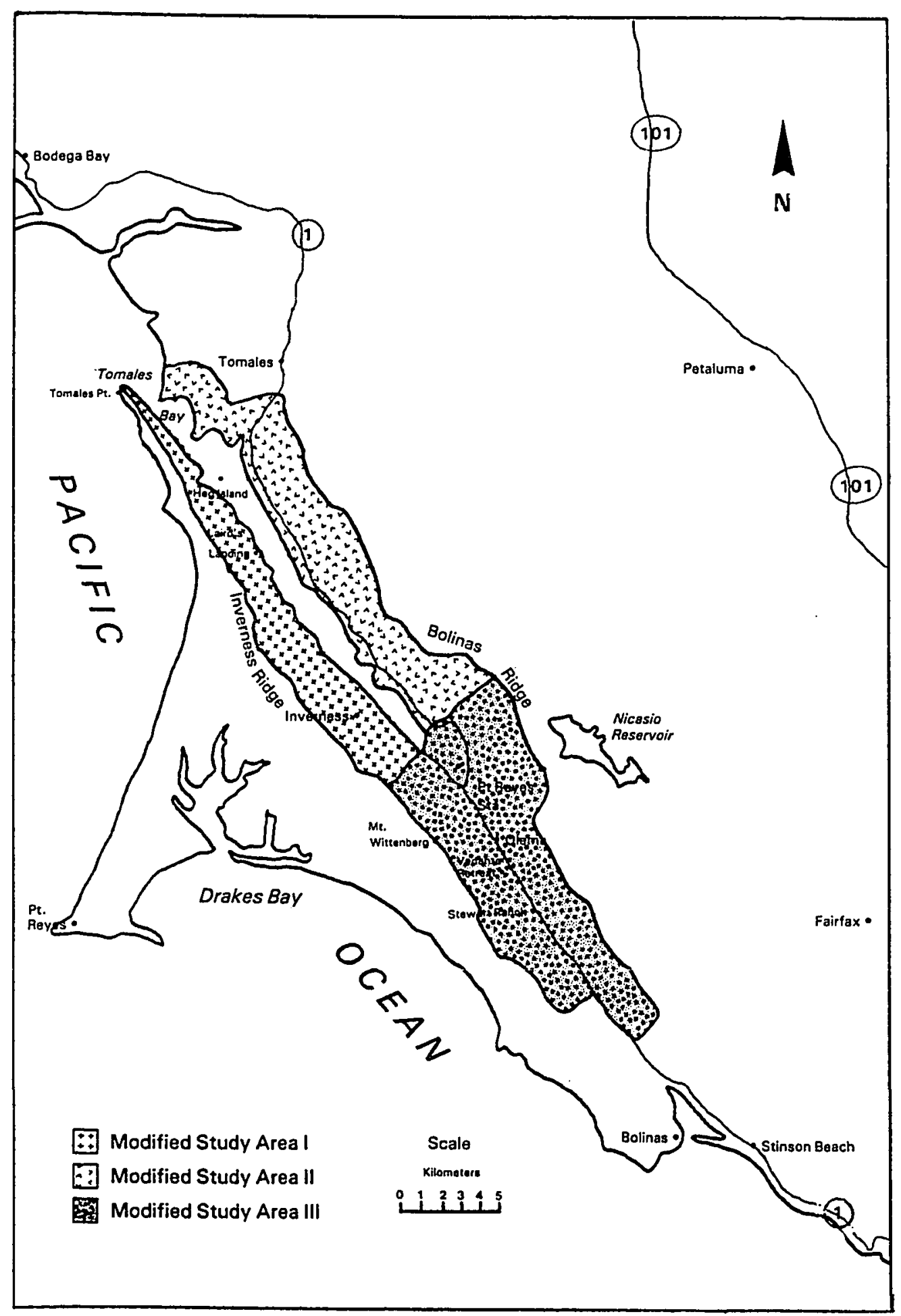

Figure 9. Modified study areas map. 
soil type and an average was calculated. The average areas for each soil type in each study area were summed and the final areas calculated.

Average Available Water Capacities

"The Soil Survey of Marin County" (United States Department of Agriculture, 1985) presented the physical and chemical properties of each soil for specific depth ranges; Table 2 is an example of data for two specific soils that comprise one generalized soil. (Note: it is the USDA standard to use English units for soils). The following is a step by step method of how average available water capacities were obtained. Initially the table might present two specific soils, Soil One and Soil Two.

For Soil One (the method is the same for Soil Two):

$\begin{array}{ll}\begin{array}{l}\text { Depth } \\ \text { range } \\ \mathrm{cm}\end{array} & \begin{array}{l}\text { Available water } \\ \text { capacity range } \\ \mathrm{cm} / \mathrm{cm}\end{array} \\ \mathrm{W}-\mathrm{X} & \text { WC1-WC2 } \\ X-Y & \text { WC3-WC4 } \\ Y-Z & \text { WC5-WC6 }\end{array}$

In order to obtain an average available water capacity for the specific soil, first an average available water capacity (AWC) was calculated for each depth.

For Soil One:

\begin{tabular}{|c|c|}
\hline $\begin{array}{l}\text { Depth } \\
\text { range } \\
\mathrm{cm}\end{array}$ & $\begin{array}{l}\text { Average available } \\
\text { water capacity } \\
\mathrm{cm} / \mathrm{cm}\end{array}$ \\
\hline $\begin{array}{l}W-X \\
X-Y \\
Y-Z\end{array}$ & $\begin{array}{l}A W C 1=(W C 1+W C 2) / 2 \\
A W C 2=(W C 3+W C 4) / 2 \\
A W C 3=(W C 5+W C 6) / 2\end{array}$ \\
\hline
\end{tabular}




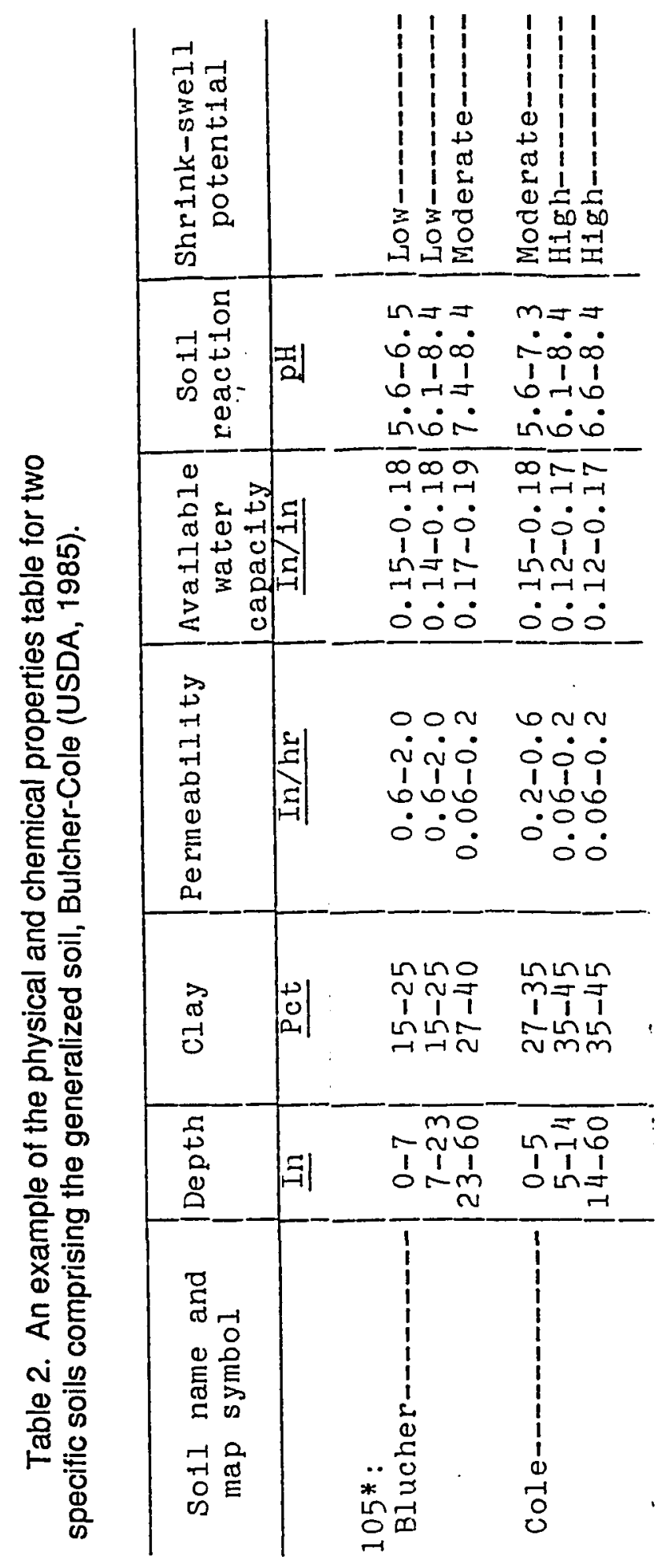


Then the percentage of each depth to the total depth was calculated and multiplied by its respective available water capacity to obtain a water capacity fraction (WCF).

For Soil One:

$\begin{array}{llll}\begin{array}{l}\text { Fraction of } \\ \text { total depth } \\ \mathrm{cm}\end{array} & \begin{array}{l}\text { Average water } \\ \text { capacity } \\ \mathrm{cm} / \mathrm{cm}\end{array} & \begin{array}{l}\text { Water capacity } \\ \text { fraction } \\ \mathrm{cm} / \mathrm{cm}\end{array} \\ (\mathrm{X}-\mathrm{W}) / \mathrm{Z} & \mathrm{X} & \text { AWC1 } & \\ (\mathrm{Y}-\mathrm{X}) / Z & \mathrm{X} & \text { AWC2 }= & \text { WCF1 } \\ (\mathrm{Z}-\mathrm{Y}) / \mathrm{Z} & \mathrm{X} & \text { AWC3 }= & \text { WCF2 } \\ & & \text { WCF3 }\end{array}$

These numbers were added and a final available water capacity (FWC1) average for specific Soil One is calculated.

$$
F W C 1=W C F 1+W C F 2+W C F 3
$$

Because the generalized soils can consist of up to three specific soil types, a final average available water capacity was calculated by an area weighted average of the water capacity for each soil. The average available water capacity (AWCG) for generalized Soils One and Two is:

$$
A W C G=(\% \text { Area } 1 \times \text { FWC } 1)+(\% \text { Area } 2 \times \text { FWC2 })
$$

\section{Soil Depth Ranges}

Soil depths were taken from the "Soil Survey of Marin County" (USDA, 1985). The soil depths in the survey were presented as a range: e.g. 20-40 inches, 40-60 inches (metric units are not used in survey). 
Where generalized soils were composed of multiple soil types of varying soil depths, an areally-weighted average of the soil's area percentage multiplied by the soil depth range was used. For example, Generalized Soil A is composed of Soils One and Two. The depth ranges of Soils One and Two are A-B and C-D respectively and the area percentages of Soils One and Two are $X$ and $Y$ respectively. First the average of the lower depth range is calculated:

$$
L D=(A \times X)+(C \times Y)
$$

Next, the upper limit depth range (UD) is calculated:

$$
U D=(B \times X)+(D \times Y)
$$

Finally an average soil depth (AD) is calculated for generalized soil $A$ :

$$
A D=L D \text { to } U D .
$$

The range is used to calculate a lower and upper limit for the water budget groundwater contribution. Generalized soil depths are presented in table 3.

\section{Runoff Rates}

Runoff is the portion of precipitation that does not infiltrate or evaporate but rather provides surface water for streamflow. Monthly runoff rates for the Tomales Bay watershed were determined as the average monthly stream flow rate divided by the watershed area for Lagunitas Creek and Walker Creek. These monthly flow rates were averaged from October 1974 to 1987 for Lagunitas Creek and from October 1968 to 1987 for Walker Creek (Ken Markham, US Geological Survey District Office Santa 
Table 3. Average water capacity and soil depth for each soil in the Tomales Bay watershed (USDA, 1985).

Soil Type

$\begin{array}{rr}\text { Average Water } & \text { Soil } \\ \text { Capacity } & \text { Depth } \\ \mathrm{cm} / \mathrm{cm} & \mathrm{cm}\end{array}$

Bulcher-Cole

0.16

152

Duneland

0.07

183

Kehoe-Inverness-Sheridan Variant

$0.12 \quad 50-100$

Palomarin-Wittenberg

$0.12 \quad 100-152$

Cronkite-Dipsea-Centissimma

$0.12 \quad 80-130$

Olompali-Felton-Soulajoule

$0.14 \quad 100-152$

Tocaloma-Saurin

$0.15 \quad 50-100$

Los Osos-Bonnydoon

$0.14 \quad 45-90$ 
Rosa, personal communication with Dr. Stephen Smith, 1987).In order to obtain single monthly runoff values, an average between Lagunitas runoff rates and Walker runoff rates was calculated (table 4). The monthly runoff rates were very similar from both drainages.

\section{Evapotranspiration Rates}

Evapotranspiration (ET), defined by Snyder et al (1987), "is the sum of evaporation (E) from soil and plant surfaces and transpiration $(T)$, which is the evaporation that takes place within plant leaves and the vapor that diffuses into the air through stomata on the leaf surfaces". ET is one of the more difficult variables in the soil moisture budget method to accurately assess because of its variable nature especially near the coast. Reference evapotranspiration (ETo), the value used in this thesis, approximates the ET of a large field of 4-to 7-inch tall, cool season grass (or uncut pasture) that is not water stressed (Snyder et al., 1987). Reference ET (ETo), determined by the University of California at Davis, Pruitt et al. (1n87) and Snyder et al. (1987), was used as the potential ET for the soil moisture budget.

In order to obtain an average potential ET for the Tomales Bay watershed, an average between the monthly ET rates of San Rafael and Fort Ross was first calculated. These cities were chosen because their ET values are listed in Pruitt et al. (1987) and because Tomales Bay is located geographically between them. Pruitt et al. (1987) calculated these ET values using pan evaporation values from each station and the above assumptions for ETo. Second, monthly ET rates for the Tomales Bay watershed were interpolated from ET isoline maps of California (Snyder et al, 1987; figures 26-37, Appendix B). Finally the average between the 
Table 4. Runoff rates for Lagunitas Creek, Walker Creek, and the Lagunitas Creek-Walker Creek average (Smith, unpublished data).

$\begin{array}{lrrr} & \begin{array}{r}\text { Lagunitas } \\ \text { Creek } \\ \mathrm{mm}\end{array} & \begin{array}{r}\text { Walker } \\ \text { Creek } \\ \mathrm{mm}\end{array} & \begin{array}{r}\text { Average } \\ \mathrm{mm}\end{array} \\ \text { Month } & & & \\ \text { Jan. } & 82.0 & 140.7 & 111.4 \\ \text { Feb. } & 115.3 & 118.9 & 117.1 \\ \text { Mar. } & 96.4 & 79.8 & 88.1 \\ \text { Apr. } & 27.6 & 23.3 & 25.5 \\ \text { May } & 5.3 & 3.7 & 4.5 \\ \text { Jun. } & 1.8 & 1.8 & 1.8 \\ \text { Jul. } & 1.4 & 1.8 & 1.6 \\ \text { Aug. } & 1.2 & 1.6 & 1.4 \\ \text { Sept. } & 1.2 & 1.7 & 1.4 \\ \text { Oct. } & 1.9 & 1.8 & 1.9 \\ \text { Nov. } & 17.1 & 21.9 & 19.5 \\ \text { Dec. } & 42.2 & 75.1 & 58.7 \\ & & & \\ \text { Total } & 393.4 & 472.1 & 432.9\end{array}$


interpolated values and the San Rafael - Fort Ross average was calculated and the results presented in table 5. The purpose of taking an average of the interpolated values and the average was to incorporate all known information to produce more accurate monthly ET rates for the Tomales Bay watershed.

\section{Precipitation Averages}

Five rain gage stations located within or near the Tomales Bay watershed, including Inverness, Point Reyes Station, Tomales, Kentfield, and Petaluma (figure 10) were used. Precipitation averages were obtained by performing a linear regression analysis on available precipitation data. The most complete period of the rainfall record for the Kentfield and Petaluma stations included from January 1968 through December 1986. The period of record for the Point Reyes Station, Inverness, and Tomales stations did not cover this entire time and therefore a regression analysis was needed to generate equivalent data for the missing time period.

Because the Kentfield and Petaluma records were complete, the three remaining rain gage stations were compared to them. The Pt. Reyes Station and Inverness precipitation records were compared to Kentfield's while the Tomales record was compared to Petuluma's because of the similar geographic location of the respective rain gage stations to each other. The years 1972 to 1981 were used for the Tomales - Petaluma and Inverness - Kentfield analysis, while the years 1975 to 1986 were used for the Point Reyes Station - Kentfield analysis. The linear equation between Pt. Reyes Station $(y)$ and Kentfield $(x)$ is $y=0.62 x+0.05$, with a correlation factor of 0.95 , between Inverness $(y)$ and Kentfield $(x)$ is $y=0.86 x+0.17$, with a correlation factor of 0.93 , and between Tomales $(y)$ and 
Table 5. Monthly evapotranspiration rates for San Rafael, Fort Ross, the San Rafael-Fort Ross average, Tomales Bay, and the average between Tomales Bay and the San Rafael and Fort Ross Average.

\begin{tabular}{|c|c|c|c|c|c|}
\hline Month & $\begin{array}{r}\text { 'San Rafael } \\
\text { mm }\end{array}$ & $\begin{array}{r}\text { "Fort Ross } \\
\mathrm{mm}\end{array}$ & $\begin{array}{r}\text { Calculated } \\
\text { Average } \\
\mathrm{mm}\end{array}$ & $\begin{array}{r}\text { *Tomales Bay } \\
\text { mm }\end{array}$ & $\begin{array}{r}\text { Final } \\
\text { Average } \\
\mathrm{mm}\end{array}$ \\
\hline Jan. & 31 & 31 & 31 & 31 & 31 \\
\hline Feb. & 34 & 36 & 35 & 36 & 36 \\
\hline Mar. & 62 & 56 & 59 & 65 & 61 \\
\hline Apr. & 84 & 75 & 80 & 75 & 76 \\
\hline May & 102 & 93 & 98 & 96 & 97 \\
\hline Jun. & 123 & 114 & 119 & 126 & 122 \\
\hline Jul. & 123 & 105 & 114 & 112 & 112 \\
\hline Aug. & 124 & 108 & 116 & 112 & 114 \\
\hline Sep. & 108 & 87 & 98 & 99 & 98 \\
\hline Oct. & 68 & 62 & 65 & 68 & 66 \\
\hline Nov. & 33 & 30 & 31 & 30 & 30 \\
\hline Dec. & 19 & 12 & 15 & 19 & 7 \\
\hline Total & 910 & 811 & 861 & 868 & 86 \\
\hline
\end{tabular}

*Data extracted from average monthly evapotranspiration rates for selected California cities (Pruitt et al., 1987).

*"Data extracted from monthly evapotranspiration isoline maps of California (Snyder et al., 1987). 


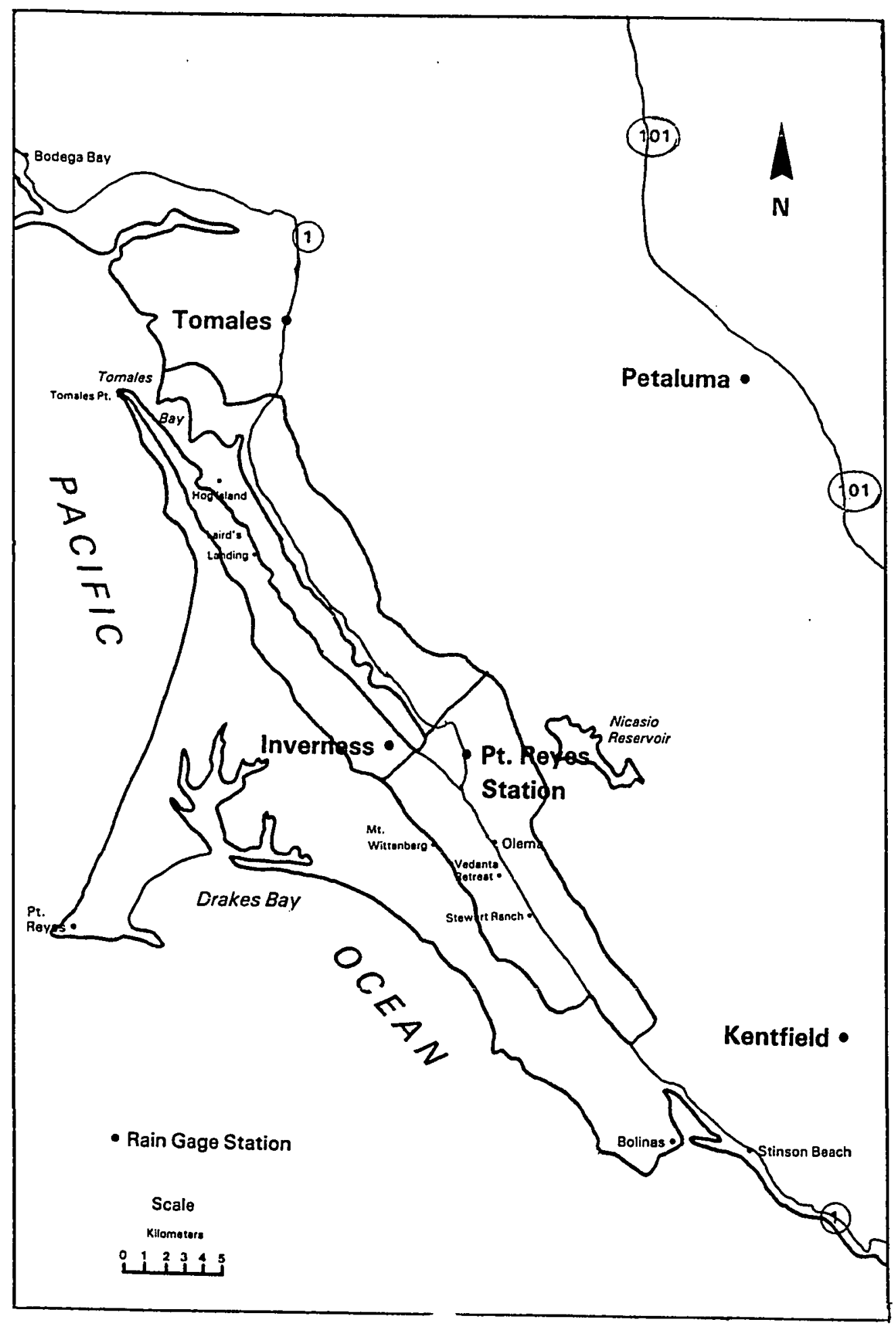

Figure 10. Location of rain gage $S$. tions in the Tomales Bay region. 
Petaluma $(x)$ is $y=0.84 x+0.32$, with a correlation factor of 0.95 .

The purpose of this regressional analysis was to produce complete records for all of the needed rain gage stations. From these complete records, a monthly average for each rain gage station was calculated for use in the water budget method analysis of the groundwater contribution to Tomales Bay. To arrive at an accuarate monthly rainfall average for each study area, the monthly precipitation average of Inverness and Tomales were used for Study Area I, of Pt. Reyes and Tomales for Study Area II, and of Inverness, Pt. Reyes Station, and Kentfield for Study Area III (figure 10). Geographically, the stations chosen for each average were located at the boundaries of the study areas. The monthly rainfall averages are presented in table 6.

Recharge and Discharge Estimates

The water budget method uses all of the previously discussed variables, average available water capacities, soil depth ranges, runoff rates, evapotranspiration rates, and precipitation averages to calculate recharge rates for each generalized soil in each modified study area. The recharge rates for the generalized soil areas are used then to calculate a discharge rate for each study area. The following is a step by step method of how a recharge rate and eventually a discharge rate is obtained for the water budget method.

Initially, monthly runoff (MR) and evapotranspiration (ET) data are subtracted from the monthly precipitation $(P)$ data resulting in the amount of water available (WA) for absorption into the soil.

$$
W A=P-M R-E T
$$




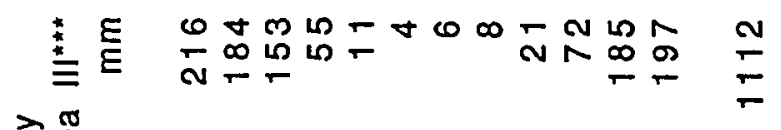

总迹

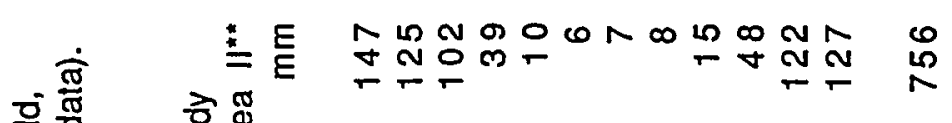

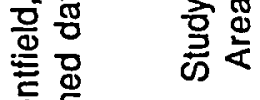

这 은

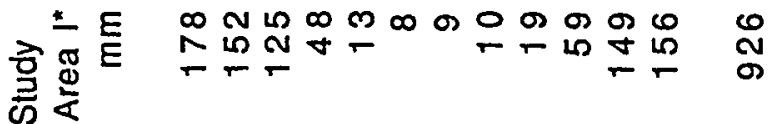

$\mathscr{8}=$

خेㅎㅀㅇ

苗

is

\&

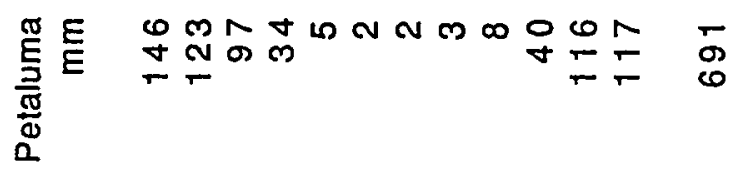


The soil moisture limit (SM) is then calculated by multiplying soil depth (SD) by soil water capacity (WC).

$$
S M=S D \times W C
$$

Month by month, the amount of water available is added (including the negative WA in the dry summer months) until the soil moisture limit is reached. Once the soil moisture limit is reached, any excess water is available for groundwater recharge (R).

$$
R=\text { SUM (MONTHLY WA) - SM }
$$

If $R$ is negative or zero no recharge occurs. If $R$ is positive, recharge does occur and SUM (WA) remains at SM. Tables 19-31b, presenting the groundwater recharge tables for all study areas, are located in Appendix D. Finally a discharge rate (D) for each study area is calculated by multiplying the total recharge rate $(R)$ for each soil in each study area by the generalized soil area (SA) for each soil in each study area and summing the product of SA and R:

$$
D=\operatorname{SUM}(S A \times R)
$$

\section{Uncertainties in Data}

The water capacity and soil depths were taken from the Soil Survey of Marin County performed by the U.S. Dept. of Agriculture and 
therefore an error could not be estimated. Runoff rates were determined by Dr. Stephen Smith by taking the average of monthly Lagunitas Creek streamflow rates divided by its drainage area and monthly Walker Creek streamflow rates divided by its drainage area. The monthly mean for Lagunitas Creek runoff was within $91 \%$ of Walker Creek's. Evapotranspiration rates were taken from studies performed by the University of California Division of Agricultureand Natural Resources (Snyder et al., 1987); (Pruitt et al., 1987). Interpolated monthly ET rates for Tomales Bay average within $5 \%$ of the calculated ET rates for Tomales Bay (the San Rafael-Fort Ross average). Therefore the final monthly ET values for Tomales Bay should vary no more than $2 \%$ to $3 \%$.

The precipitation values for each study area were calculated from average monthly precipitation from five rain gage stations in or near the Tomales Bay watershed. An average was taken of stations located near the perimeter of each study area. When comparing the Study Area I yearly average (table 7) to an interpolated value from plate 4 (note: plate 4 is the average rainfall for one year, 1976), it is found that the calculated average of $904 \mathrm{~mm}$ is $14 \%$ higher than the interpolated value of $762 \mathrm{~mm}$. For Study Area II it is found that the calculated average of $762 \mathrm{~mm}$ is the same as the interpolated. Study Area III's calculated average of $1,118 \mathrm{~mm}$ is within $5 \%$ of the interpolated value of $1,067 \mathrm{~mm}$. The generalized soil areas were measured twice with a planimeter and were within $5 \%$ of each other. The soil moisture budget is very sensitive to changes of its input variables (i.e., a small change in an input or output can produce a larger change in the recharge calculated). In addition the averaging of input variables can be 
a source of error in recharge calculations.

\section{Darcy's Law Method}

Darcy's Law method was designed to use the principles of Darcy's Law for fluid flow,

$$
\begin{aligned}
& Q=-K A d h / d l \\
& \text { where: } \mathrm{Q} \text { : discharge rate }\left(\mathrm{L}^{3} \mathrm{~T}^{-1}\right) \\
& \mathrm{K} \text { : hydraulic conductivity }\left(\mathrm{LT}^{-1}\right) \\
& A \text { : cross sectional area }\left(L^{2}\right) \\
& \text { dh/dl: hydraulic head gradient () }
\end{aligned}
$$

Because the area equals the width (W) times the thickness (b) of the aquifer and Transmissivity $(T)$ equals $(K)$ times (b), this equation can be written as:

$$
\begin{aligned}
& Q=-T \text { W dh/dl } \\
& \text { where: } Q \text { : discharge rate }\left(\mathrm{L}^{3} \mathrm{~T}^{-1}\right) \\
& \mathrm{T} \text { : transmissivity }\left(\mathrm{L}^{2} \mathrm{~T}^{-1}\right) \\
& \mathrm{W} \text { : length of the discharge zone (L) } \\
& \text { dh/dl: hydraulic head gradient }()
\end{aligned}
$$

The assumptions involved with utilizing Darcy's Law in the Tomales Bay watershed are:

1) groundwater flows downgradient through the aquifers and discharges into Tomales Bay; and

2) seepage occurs along the shoreline or through the bottom sediments. 
Bokuniewicz (1980) supports this notion by describing seepage rates as an exponentially decreasing function of distance, with lower seepage rates found further from the shoreline. The bay mud that Daetwyler (1966) describes in his marine study of Tomales Bay may play some role in reducing groundwater seepage from the southern bayshore to Tomales Bay. In addition, the San Andreas fault may serve as a conduit for the minor amounts of deeper groundwater to seep into the middle of the bay.

Transmissivity (T)

For Study Areas I and II, transmissivity values were obtained from pump tests performed by the Marin County Department of Environmental Health. First, drawdown and discharge rates were obtained from the pump test data. The specific discharge/transmissivity curve method of Walton (1970) was used to determine the value of transmissivity for each test. For Study Area I, all the transmissivity values from available pump test data were used. For Study Area II, however, only the transmissivity values indicative of weathered Franciscan (lower values) were used. Two high transmissivity values from the Millerton Formation were not included as they represent an extremely small potion of the study area. For Study Area III, pump test data from the Marin County Environmental Health Department did not exist.

An average hydraulic conductivity of the gravels in the San Andreas trough was calculated by the North Marin County Water District (1987). They estimated, from three pump tests, that the hydraulic conductivity of the gravels was at least $114 \mathrm{~m} / \mathrm{d}(375 \mathrm{ft} / \mathrm{d})$. Therefore $114 \mathrm{~m} / \mathrm{d}(375 \mathrm{ft} / \mathrm{d})$ was chosen as an approximate hydraulic conductivity value for Study Area III. 
Driller's reports indicated that the thickness of the gravels in the northern trough region was approximately $6-12$ meters $(20-40 \mathrm{ft}$ ). Therefore the transmissivity $(9 \mathrm{~m} \times 114 \mathrm{~m} / \mathrm{d})$ of the trough gravel is assumed to be 1000 $\mathrm{m}^{2} / \mathrm{d}\left(10,000 \mathrm{ft}^{2} / \mathrm{d}\right)$. Transmissivity values are listed in table 7 .

Discharge Length (W)

For Study Areas 1 and II, the length of the discharge zones (W) was 21.5 kilometers (13 miles). The lengths of the discharge zone for these areas were assumed to be the length of the shorelines. For Study Area III, the length of the shoreline was 1.4 kilometers ( 0.85 miles).

Hydraulic Head Gradient (dh/dl)

Well data in the Inverness Ridge region, Study Area I, indicated that $\mathrm{dh} / \mathrm{dl}$, the hydraulic gradient, closely approximated the topographic gradient (California Department of Water Resources, 1978). Plate 5 shows depth to water information for scattered wells in the Inverness area. Because a scarcity of water level data existed for Study Area II and III, a topographic gradient was used to closely approximate $\mathrm{dh} / \mathrm{dl}$ in both study areas. Topographic gradients were obtained from maps for all study areas.

Uncertainties in Data

Transmissivity values used for Study Areas I and II should vary within an order of magnitude, 0.1 to $1 \mathrm{~m}^{2} / \mathrm{d}$ for Study Area $\mathrm{I}$ and 0.01 to $0.1 \mathrm{~m}^{2} / \mathrm{d}$ for Study Area II. Hydraulic conductivity values for gravels located in Study Area III were taken from North Marin County Water District pump tests (NMCWD, 1987) performed in that area. Pump tests were performed on three separate dates on one well and the values averaged. The 
Table 7. Transmissivity values for Study Areas I, II, and III.

$\begin{array}{lcr}\text { Well Location } & \text { Study Area } & \begin{array}{r}\text { Transmissivity } \\ \mathrm{m}^{2} / \mathrm{d}\end{array} \\ \text { 255 Camino Del Mar } & \mathrm{S} 1 & 0.06 \\ \text { 1 Pine Hill Rd. } & \mathrm{S} 1 & 0.25 \\ \text { 172 Highland Way } & \mathrm{S} 1 & 1.00 \\ 525 \text { Vision Rd. } & \mathrm{S} 1 & 0.37 \\ \text { 56 Drakes Summit } & \mathrm{S} 1 & 0.12 \\ \text { 14 Drakes Summit } & \mathrm{S} 1 & 0.87 \\ \text { 70-80 Drakes Summit } & \mathrm{S} 1 & 0.12 \\ \text { 22505 Route 1 \#1 } & \mathrm{S} 2 & 0.03 \\ \text { 22505 Route 1 \#2 } & \mathrm{S} 2 & 0.01 \\ \text { 22495 Route 1 } & \mathrm{S} 2 & 0.12 \\ \text { *16000 Route 1 } & \mathrm{S} 2 & 12.40 \\ \text { "Route 1 } & \mathrm{S} 2 & 14.90 \\ \text { Pt. Reyes Sta. Gravels } & \mathrm{S} 3 & 1000.00\end{array}$

*Not included in average because not consistent with transmissivities of the Franciscan Complex, the dominant rock type in Study Area II. 
value given for an average gravel hydraulic conductivity was considered a low estimate by the North Marin County Water District "because the equations used presume a uniform flow field around the well, whereas, under actual conditions, the greatest part of the flow is in the direction from Lagunitas Creek to the well, which is also the direction along which permeabilities were calculated" (North Marin County Water District, unpublished report).and should vary within an order of magnitude. The seepage lengths for Study Areas I, II, and III were the Tomales Bay shoreline within each sudy area. These should be fairly accurate and vary no more than $5 \%$.

The gravel thicknesses ranged from 6 to 12 meters and should vary no more than approximately $30 \%$ from the average thickness value of 9 meters. Depth to water information for wells in the Inverness Ridge confirms the assumption that the water table closely approximates the topography in a subdued manner (Plate 5). Because groundwater is found in the same type of material, weathered bedrock, on the Bolinas Ridge as on the Inverness Ridge, this assumption should hold true for the Bolinas Ridge also. The dh/dl values for Study Area I ranged from 0.12 to 0.22 with an average of 0.15 and should vary within $12 \%$ of this average. The $d h / d l$ values for Study Area II ranged from 0.12 to 0.17 with an average of 0.145 and should vary no more than $12 \%$ from this average. The average $d h / d l$ for Study Area III was more difficult to ascertain because of its more subtle topography and lack of water level data. This value should vary within less than an order of magnitude of the average 0.004 . 


\section{STUDY RESULTS}

\section{Quantification of Groundwater Discharge Rate}

The groundwater discharge rate is obtained by averaging the two methods used in this analysis, Soil Moisture Budget and Darcy's Law. The difference in the methods of determining $D$ (discharge rate) is that the Soil Moisture Budget $D$ is dependent on precipitation, runoff, evapotranspiration, and a soil moisture budget while Darcy's Law is dependent on the hydraulic parameters of the region's aquifers. In addition, the Soil Moisture Budget $D$ is related to recharge rates while Darcy's Law's $D$ is related to flow rates.

\section{Soil Moisture Budget Method Discharge Rate}

Using the upper and lower limit groundwater recharge rates per year (Appendix D, tables 19-31b) for each soil and multiplying by the soil's area in each study area, a discharge rate for each soil was calculated (table 8). The recharge rate was considered to be equal to the discharge rate on an average or pseudo-steady state basis.

The following is a summary of the upper and lower limit groundwater discharge rates irom each study area.

Study Area III has the greatest discharge rate when compared to the other study areas. One would expect to find more discharge from Study Area III due to its higher precipitation rate, greater watershed area, and greater permeability of the area's sediments. Study Area I would have the next highest discharge rate because its precipitation rate and sediment permabilities are greater than that of Study Area II. The total lower and upper limit discharge rates to Tomales Bay are $4.2 \times 10^{4} \mathrm{~m}^{3} / \mathrm{d}$ and $5.7 \times$ 

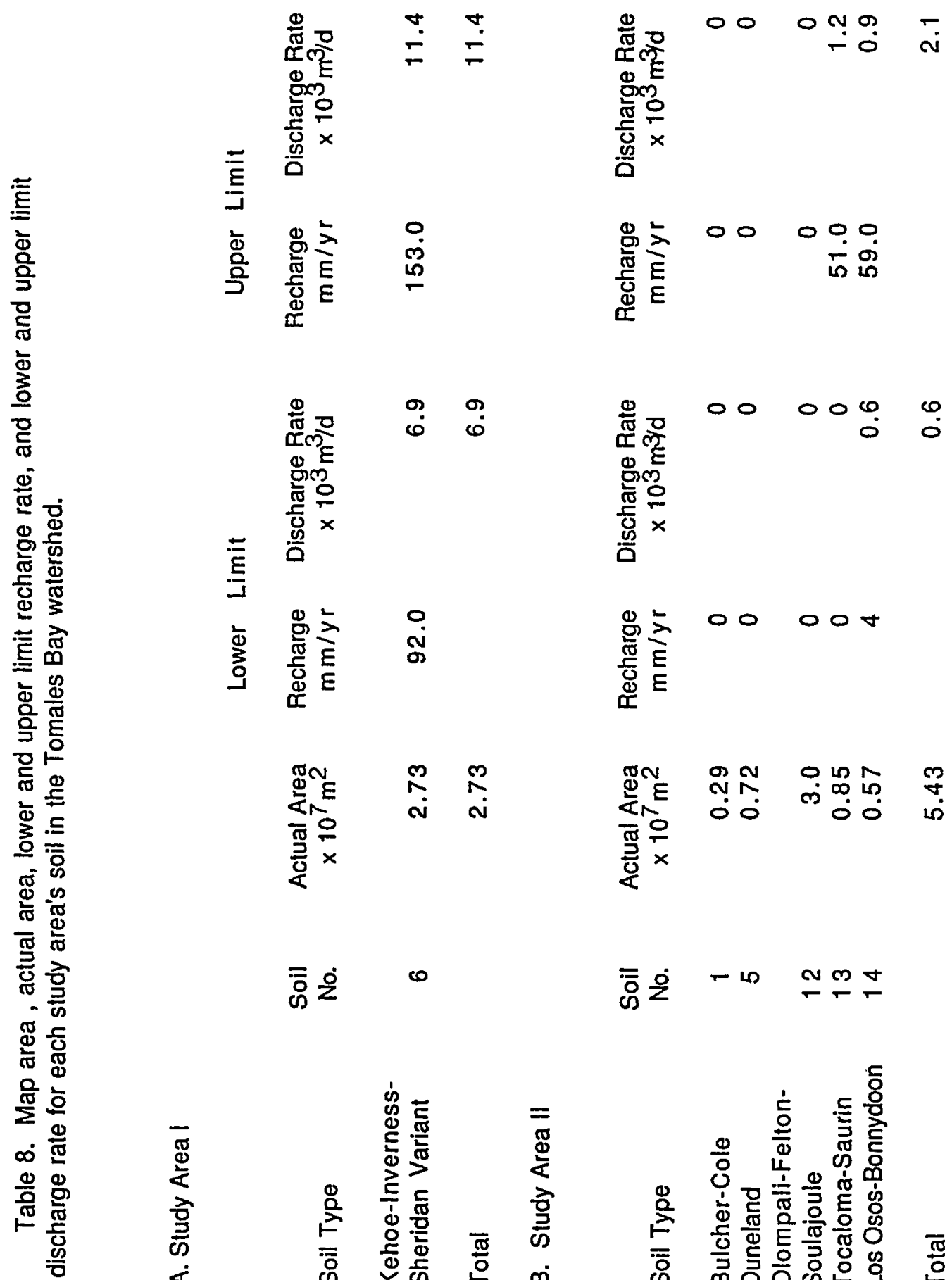

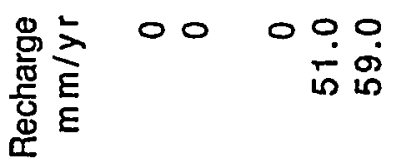

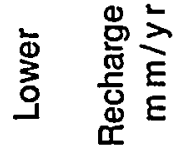

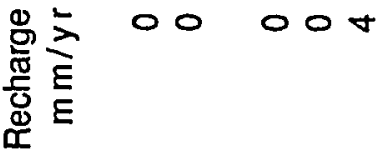

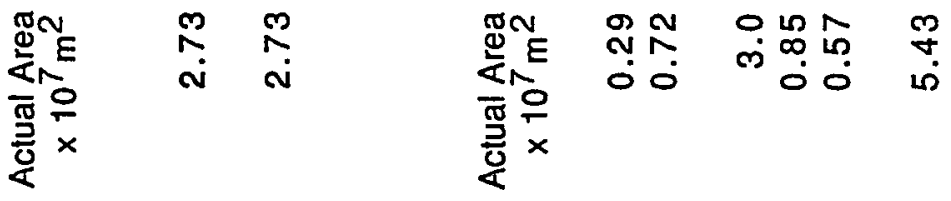

홍ํํ

$\infty$

就운

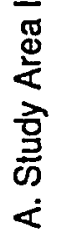
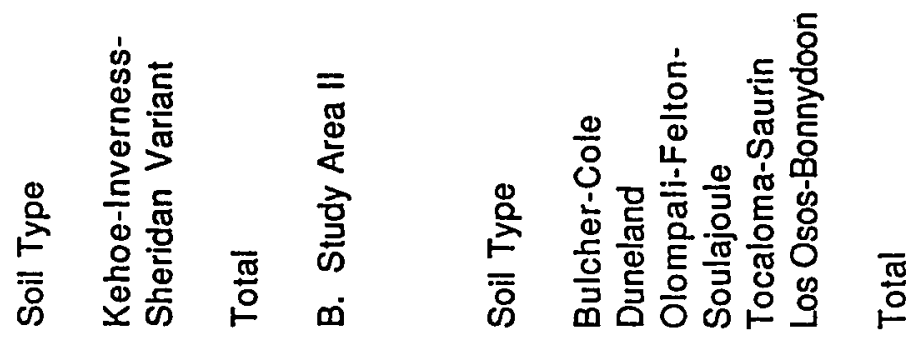

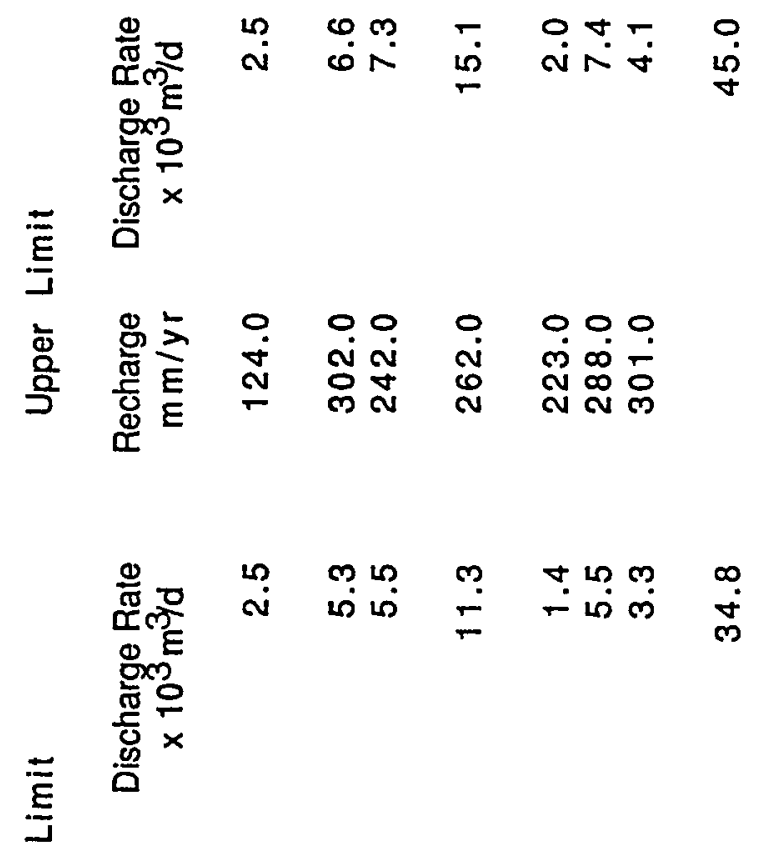

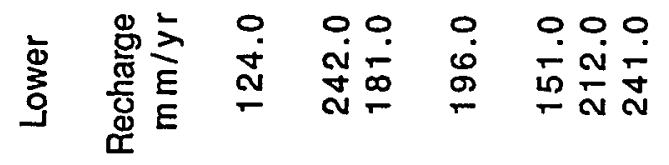

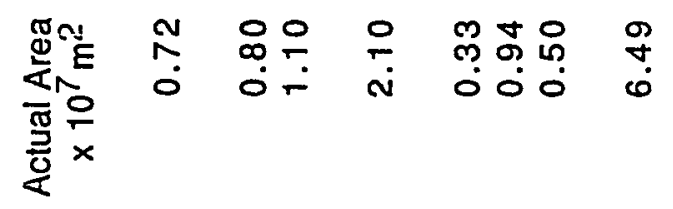

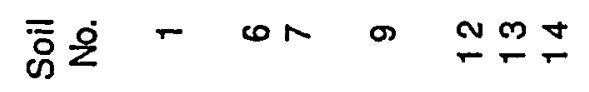

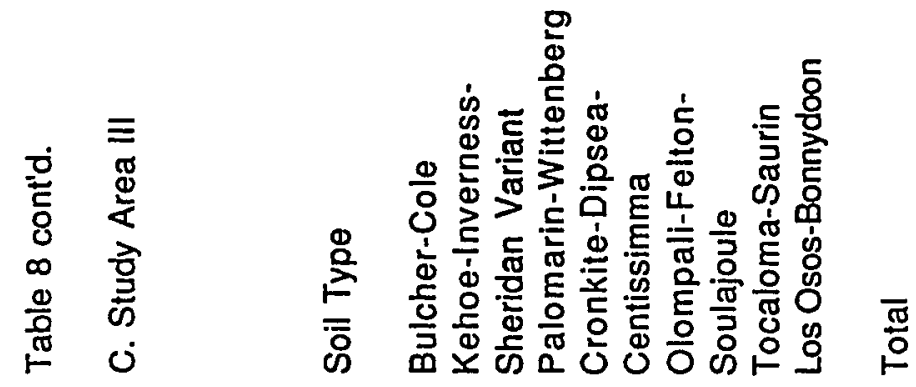


$10^{4} \mathrm{~m}^{3} / \mathrm{d}$ respectively (table 9 ).

Darcy's Law Discharge Rate

The total discharge to Tomales Bay as calculated by the Darcy's Law method is $7.1 \times 10^{3} \mathrm{~m}^{3} / \mathrm{d}$ (table 10). Study Area III contributes the most water to Tomales Bay, with Study Area I next and Study Area II following. Study Area III has the greatest discharge rate primarily due to the high permeability and thickness of its alluvial sediments. The Franciscan rock material found in Study Area II has the lowest hydraulic conductivity and, therefore, Study Area II has the lowest discharge rate to Tomales Bay.

\section{Combined Goundwater Discharge Rates}

Combined discharge rates from each study area were calculated to aid future assessments. In order to simplify future calculations, an average discharge rate for each study area was calculated for all methods. First, the average of the upper and lower limit water budget discharges for each study area were calculated. This average was averaged with the Darcy's Law discharge rate and a final average was obtained. The final average groundwater discharge rates for Study Area I, II, and III are $5.2 \times 10^{3} \mathrm{~m}^{3} / \mathrm{d}$, $0.6 \times 10^{3} \mathrm{~m}^{3} / \mathrm{d}$, and, $22.7 \times 10^{3} \mathrm{~m}^{3} / \mathrm{d}$ respectively. The total groundwater discharge rate to Tomales Bay is $28.5 \times 10^{3} \mathrm{~m}^{3} / \mathrm{d}$.

\section{Nutrient Concentrations}

The nutrients considered for this study are phosphate $\left(\mathrm{PO}_{4}\right)$, nitrate-nitrite $\left(\mathrm{NO}_{3} / \mathrm{NO}_{2}\right)$, ammonium $\left(\mathrm{NH}_{4}\right)$, silica $(\mathrm{Si})$ and dissolved inorganic carbon (DIC). Other chemical parameters examined are $\mathrm{pH}$, 
Table 9. Discharge rates from each study area for Soil Moisture Budget lower limit, and Soil Moisture Budget upper limit.

$\begin{array}{rrr} & \begin{array}{r}\text { Lower Limit } \\ \text { Discharge Rate } \\ 10^{3} \mathrm{~m}^{3} / \mathrm{d}\end{array} & \begin{array}{r}\text { Upper Limit } \\ \text { Discharge Rate } \\ 10^{3} \mathrm{~m} / \mathrm{d}\end{array} \\ \text { Study Area } & & \\ \text { S1 } & 6.90 & 11.40 \\ \text { S2 } & 0.60 & 2.10 \\ \text { S3 } & 34.60 & 45.04 \\ \text { Total } & 42.10 & 58.54\end{array}$

Table 10. Darcy's Law discharges for all study areas in the Tomales Bay watershed.

$\begin{array}{rrrrr}\text { Study Area } & \begin{array}{r}\text { Transmissivity } \\ \mathrm{m}^{2 / \mathrm{d}}\end{array} & \begin{array}{r}\text { Seepage Length } \\ \mathrm{km}\end{array} & \text { Head Gradient } & \begin{array}{r}\text { Discharge rate } \\ 10^{3} \mathrm{~m} / \mathrm{d}\end{array} \\ \text { S1 } & 0.41 & 21.5 & 0.15 & \\ \text { S2 } & 0.05 & 21.5 & 0.145 & 1.3 \\ \text { S3 } & 1000.0 & 1.4 & 0.004 & 0.2 \\ & & & & 5.6 \\ \text { alscharge } & & & & 7.1\end{array}$


alkalinity, temperature, and conductivity. Table 17 (Appendix C) contains the results of analyses on water samples for $\mathrm{PO}_{4}, \mathrm{NO}_{3} / \mathrm{NO}_{2}, \mathrm{NH}_{4}, \mathrm{Si}$, and DiC. Table 18 (Appendix C) contains $\mathrm{pH}$, alkalinity, temperature, and conductivity. Table 11 contains the calculated means and standard deviations for all variables analyzed. The number of samples collected in Study Area I, Study Area II, and Study Area III are 20, 22 and 9, respectively. It can be noted from Table 11 that parameters that reflect natural $(\mathrm{Si}, \mathrm{pH}, \mathrm{Alk})$ rather than anthropogenic sources $(\mathrm{P}, \mathrm{N})$ have much smaller sample variability, i.e., a smaller standard deviation.

Phosphate $\left(\mathrm{PO}_{4}\right)$

Phosphate from natural sources is generally rare in groundwater. When present, it most likely has originated artificially from sewage, fertilizer, or animal wastes. In the Tomales Bay watershed phosphate is present in all study areas. The phosphate concentration ranges for Study Area 1, Study Area II and Study Area III are 0.05 to 10.18 micromoles/liter, 0.05 to 2.64 micromoles/liter, and 0.12 to 46.26 micromoles/liter, respectively. The average phosphate concentrations in Study Area I and Study Area II are fairly similar, $0.76 \pm 1.3 \mathrm{micromoles} / \mathrm{liter}$ and $0.75 \pm 0.79 \mathrm{micromoles} / \mathrm{liter}$ respectively. The concentration of phosphate, $3.45 \pm 3.1$ micromoles/liter, in Study Area III is nearly seven times greater than that of I and II, 3.45 \pm 3.1 micrmoles/liter (figure 11). This is probably due to the numerous dairies and farms that exist in this area. Phosphate levels in Study Area I are most likely caused by seepage from septic systems, whereas, Study Area II levels are affected by both animal wastes and septic system seepage. Another possible explanation for the higher levels of phosphate in Study Area III's groundwater is related to phosphate's ability to adsorb to soil particles. 


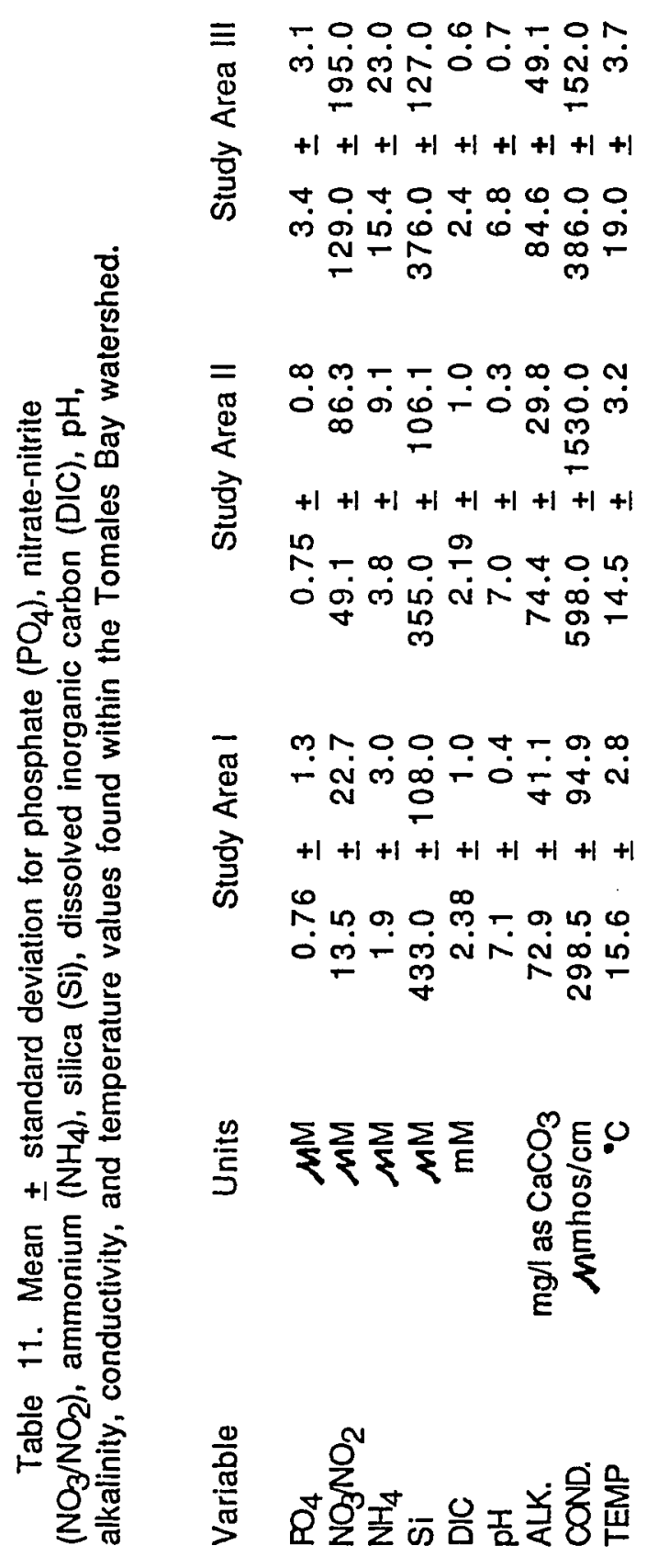




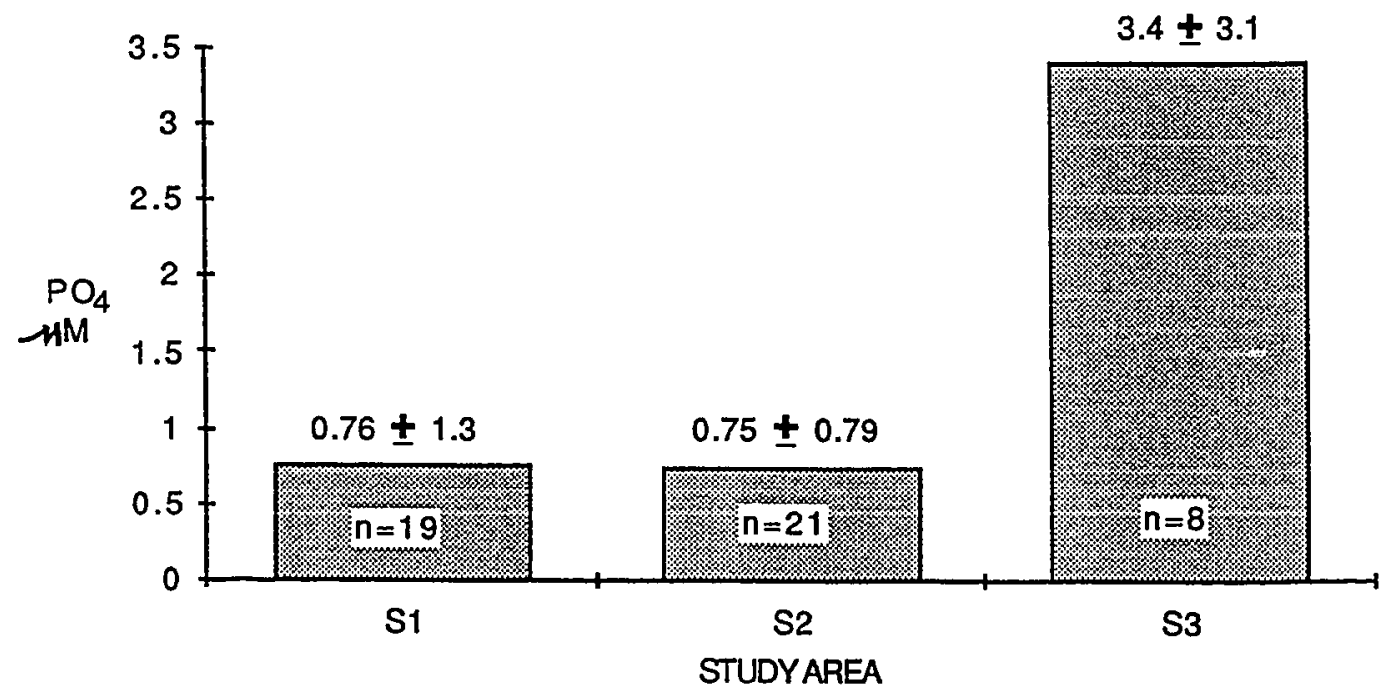

Figure 11. Average posphate concentrations for well samples from each study area. 
Because the grain size of the aquifer sediments in the trough is so much greater than either Study Area I or II and less clay and organic material exist in the Study Area III gravels, less surface area exists to which the phosphate can adsorb to therefore making it more mobile.

Nitrate-Nitrite $\left(\mathrm{NO}_{3} / \mathrm{NO}_{2}\right)$

Naturally occurring nitrogen in the form of nitrate is added to the groundwater system through rainfall, leaching from the soil, and wild animal waste products. Some $\mathrm{NO}_{3}$ is added to the groundwater through nitrification, where $\mathrm{NH}_{4}$ is converted to $\mathrm{NO}_{3}$ by oxidation (Freeze and Cherry, 1979). Humans increase nitrate concentrations in groundwater through agricultural practices (domesticated animal wastes and fertilizers), leaking municipal sewers, septic systems, and improperly designed landfills. Figure 12 is a flow chart representation of the nitrogen cycle in the Tomales Bay watershed.

In the Tomales Bay watershed, average nitrate concentrations are the greatest in Study Area III, $129.0 \pm 195.0$ micromoles/liter (figure 13). This is likely due to the high density of farms and dairies located in this region. Study Area II has the second greatest nitrate concentration in the Tomales Bay watershed, 49.1 86.3 micromoles/liter, resulting from the existence of dairies in the northern and southern sections of this area and septic tank discharge from residential areas. Study Area I, with no dairies or farms, has the lowest nitrate concentration, $13.46 \pm 22.7$ micromoles/liter (figure 13). The only possible contaminant source for Study Area $I$ is leaking septic systems. High standard deviations are noticeable for all the study areas and are due to the variable nitrate concentrations found in the Tomales Bay watershed. The nitrate-nitrite concentration ranges for Study Area I, 


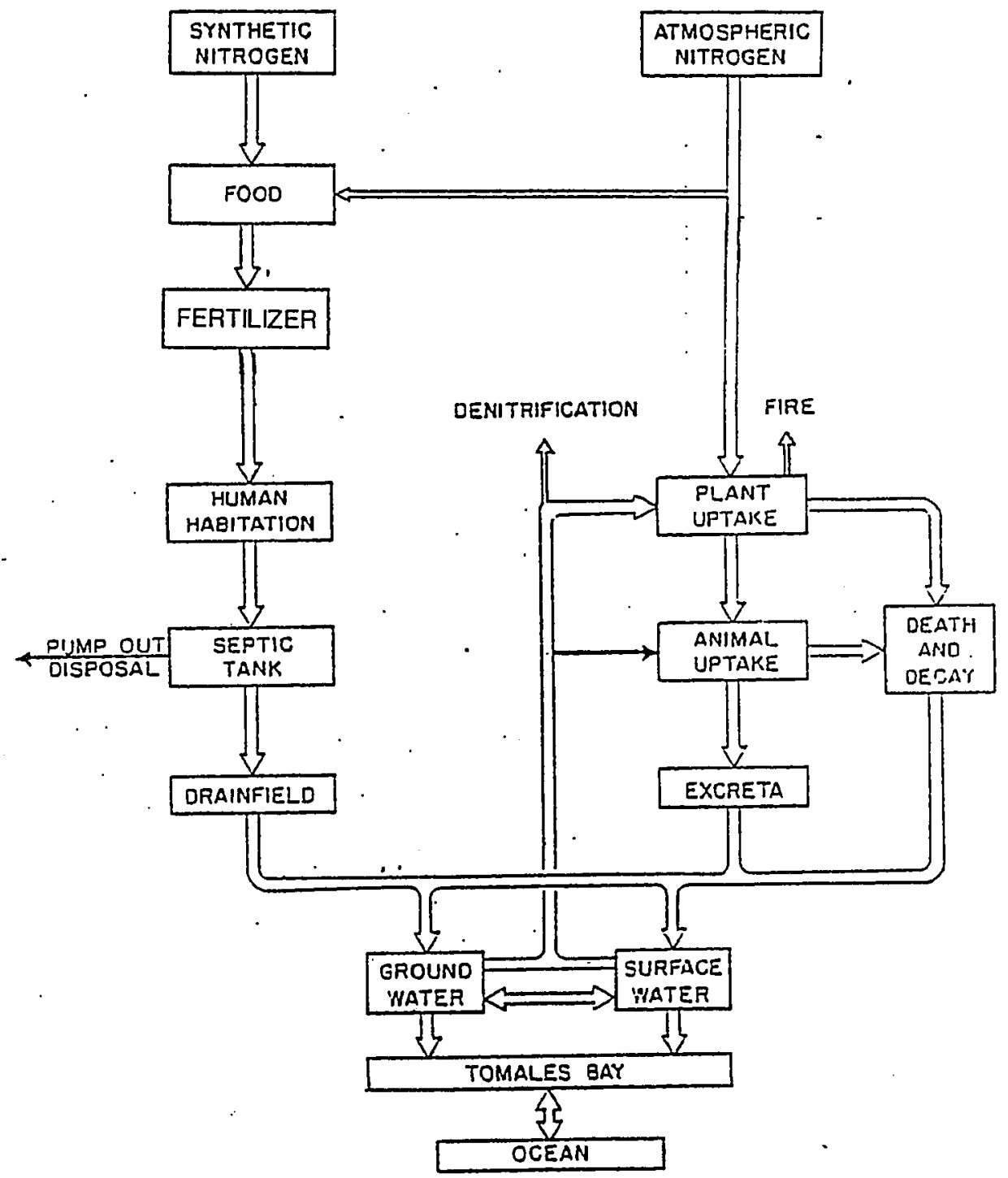

THE NITROGEN CYCLE

Figure 12. Flow chart of the nitrogen cycle in the Tomales Bay watershed (Cooper and Clark, 1976). 


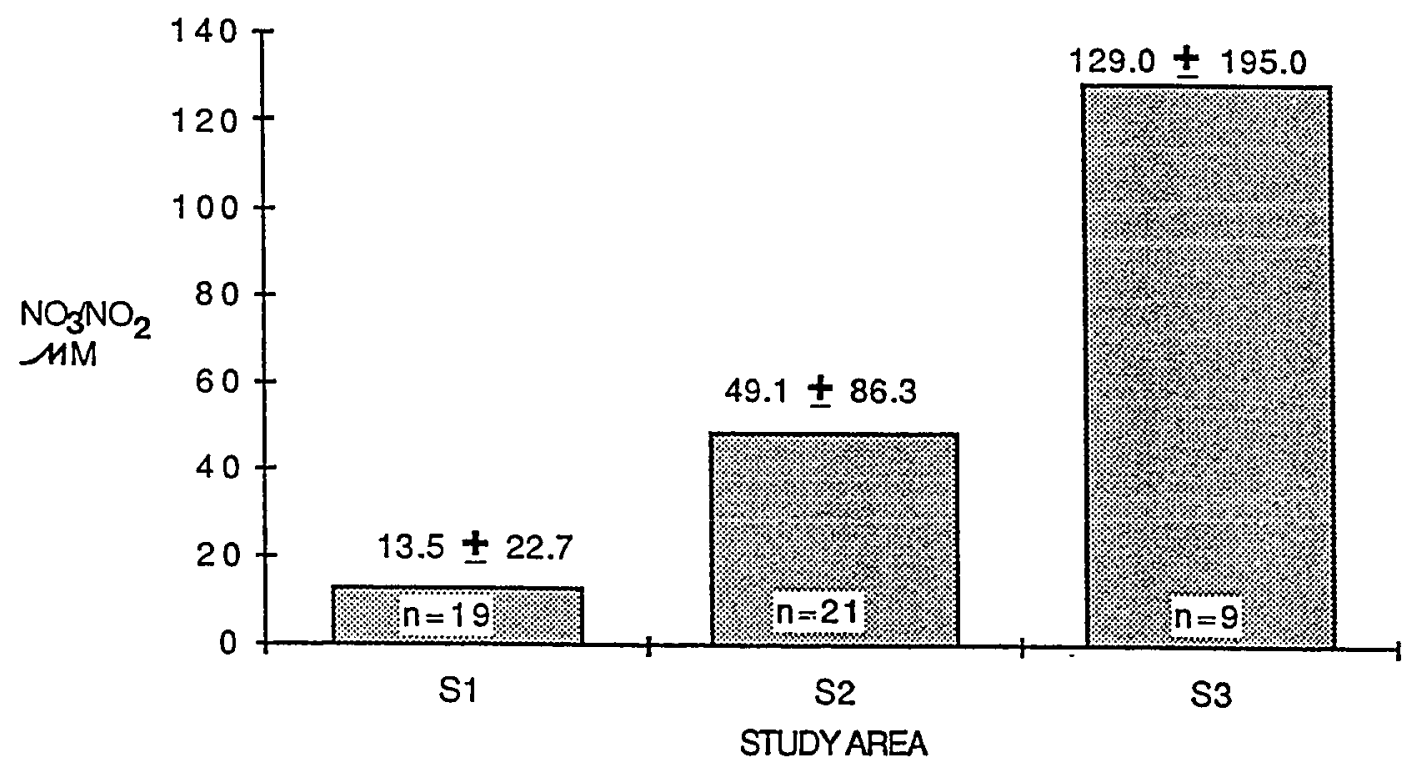

Figure 12. Average nitrate-nitrite concentrations for well sample from each study area. 
Study Area II, and Study Area III are 0.36 to 89.14 micromoles/liter, 0.03 to 413.69 micromoles/liter, and 0 to 494.91 micromoles/liter, respectively.

Ammonium $\left(\mathrm{NH}_{4}\right)$

Ammonium enters groundwater from animal wastes and septic system seepage. Ammonification, where organic nitrogen is converted to ammonium (NH4), is another contributing factor (Freeze and Cherry, 1979). Ammonium concentrations in the Tomales Bay watershed are similar in proportion to nitrate concentrations, with the greatest in Study Area III, 15.4 \pm 3.0 micromoles/liter, the next, in Study Area II, $3.8 \pm 9.1$ micromoles/liter, and the least in Study Area I, $1.9 \pm 3.0$ micromoles/liter (figure 14). The ammonium concentration ranges for Study Area I, Study Area II, and Study Area III are 0.04 to 175.64 micromoles/liter, 0.2 to 163.36 micromoles/liter, and 0.51 to 721.2 micromoles/liter, respectively. Because ammonium is a by-product of animal and human wastes, the previous explanation for the nitrate concentration is applicable here as well.

Silica (Si)

The main source of silica in groundwater is parent rock rich in silica. The granitic rocks of Study Area I are high in silica. Therefore, the groundwater in the decomposed granite would be expected to have elevated concentrations of Si. In comparison to Study Area I, Study Areas II and III would be expected to have somewhat lower Si concentrations. The concentrations for Study Areas I, II, and III are $433.0 \pm 108.0$ micromoles/liter, $355.0 \pm 106.0$ micromoles/liter, and $376.0 \pm 127.0$ micromoles/liter respectively (figure 15), while the silica concentration ranges for Study Area I, Study Area II, and Study Area III are 223.26 to 


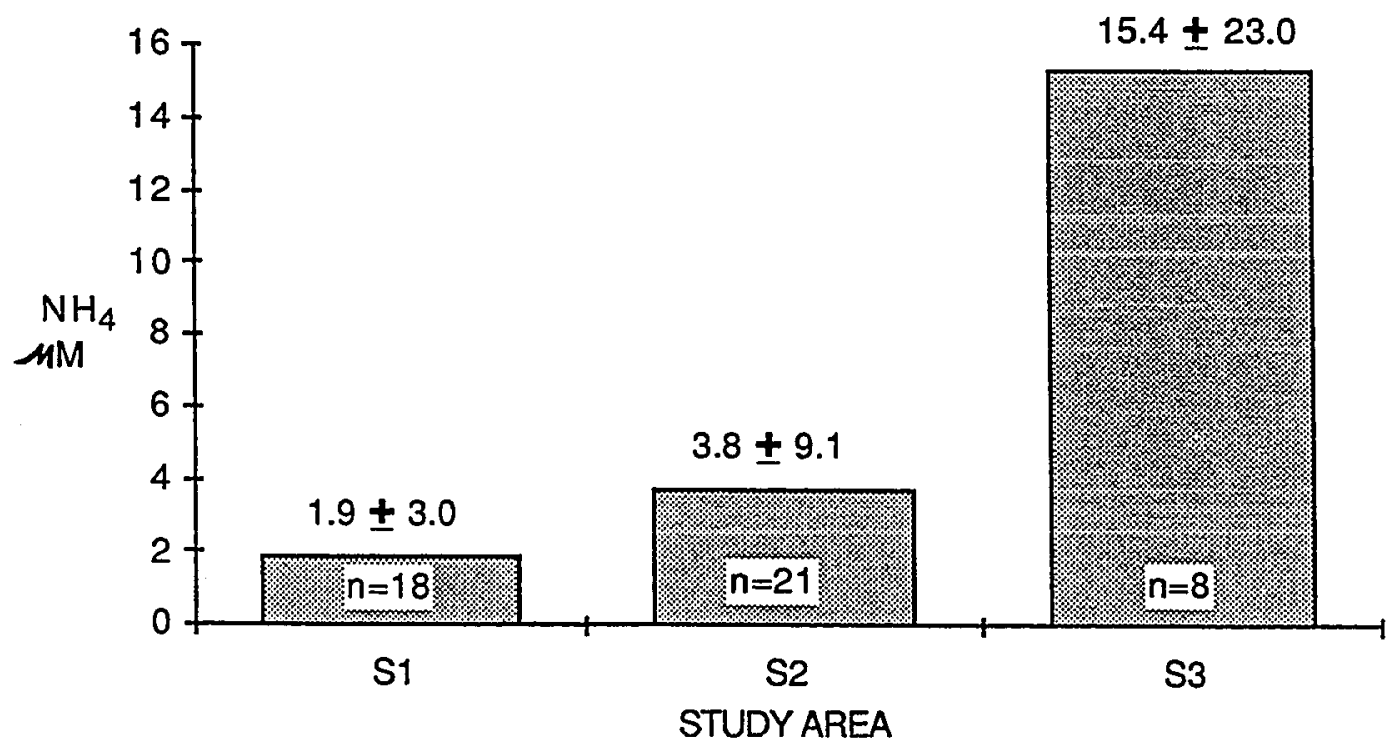

Figure 14. Average ammonium concentrations for well samples from each study area. 


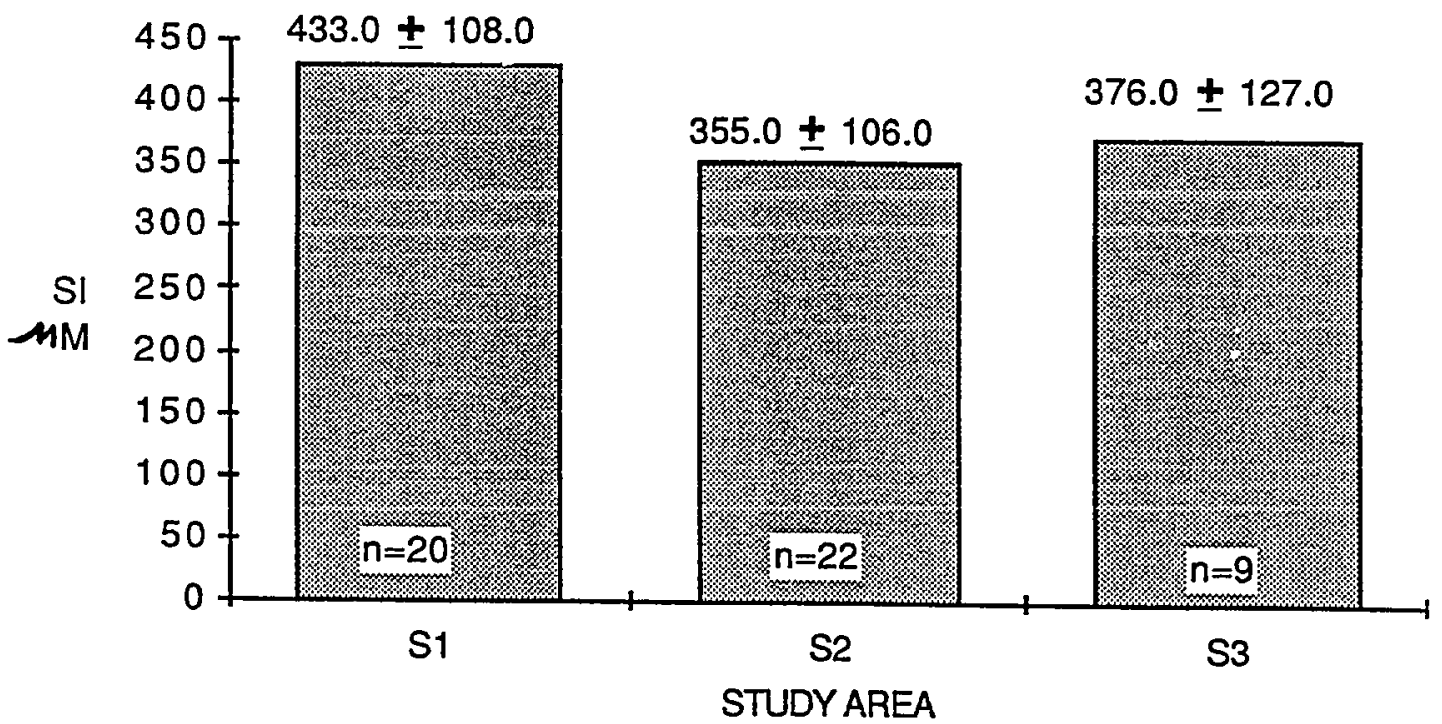

Figure 15. Average silica concentrations for well samples from each study area. 


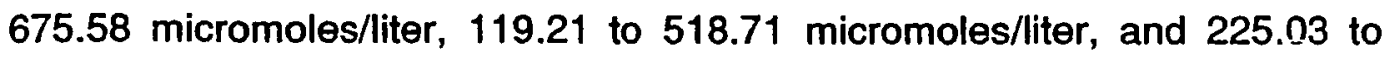
825.90 micromoles/liter, respectively.

$\mathrm{pH}$

The average $\mathrm{pH}$ of the groundwater in the Tomales Bay watershed is approximately the same in the three study areas with an average $\mathrm{pH}$ for each study area close to neutral, $\mathrm{pH} 7$ (figure 16). The $\mathrm{pH}$ ranges for Study Area I, Study Area II, and Study Area III are 6.50 to 8.24, 6.21 to 7.89, and 6.05 to 8.05 , respectively.

Alkalinity

A major source of alkalinity is dissolution of carbonate materials. Minor amounts of limestone exist in each study area and contribute to the concentration of alkalinity.

The alkalinity of the groundwater in the Tomales Bay watershed is variable. Study Areas I and II are more closely related with alkalinities of $72.9 \pm 41.1 \mathrm{mg} / \mathrm{l}$ as $\mathrm{CaCO}_{3}$ and $74.4 \pm 29.8 \mathrm{mg} / \mathrm{l}$ as $\mathrm{CaCO}_{3}$, respectively (figure 17). Study Area III has an alkalinity of $84.6 \pm 49.1 \mathrm{mg} / \mathrm{l}$ as $\mathrm{CaCO}_{3}$. The alkalinity ranges for Study Area I, Study Area II, and Study Area III are 0 to $144.5 \mathrm{mg} / \mathrm{l}$ as $\mathrm{CaCO}_{3}, 25$ to $166 \mathrm{mg} / \mathrm{l}$ as $\mathrm{CaCO}_{3}$, and 30 to $167.50 \mathrm{mg} / \mathrm{l}$ as $\mathrm{CaCO}_{3}$, respectively.

Dissolved Inorganic Carbon (DIC)

Dissolved inorganic carbon in groundwater results from dissolution of carbonate rock, oxidation of organics, and dissolved atmospheric $\mathrm{CO}_{2}$. In the Tomales Bay watershed, the DIC concentrations are similar in all study areas. Study Areas I had a concentration of $2.38 \pm 1.01$ millimoles/liter, Study Area II had $2.19 \pm 1.04$ millimoles/liter, and Study Area III had $2.38 \pm$ 


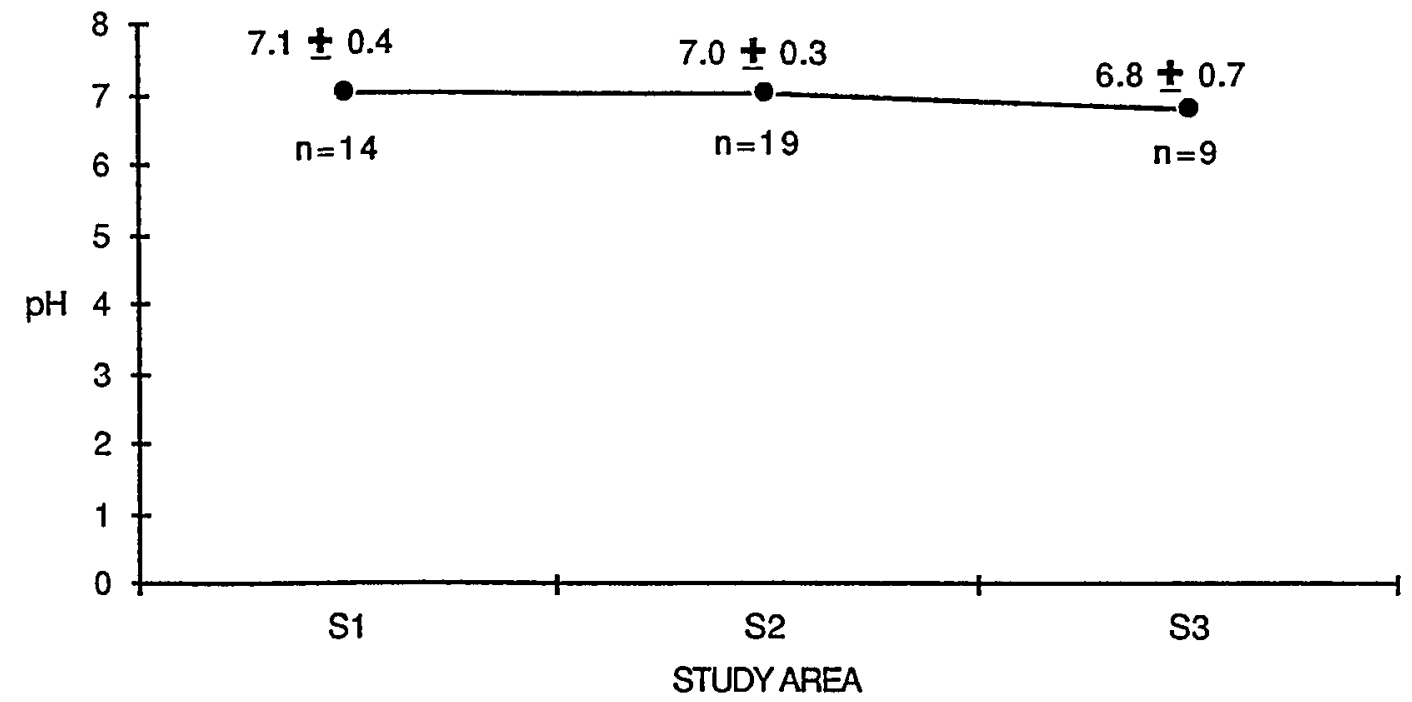

Figure 16. Average $\mathrm{pH}$ for well samples from each study area. 


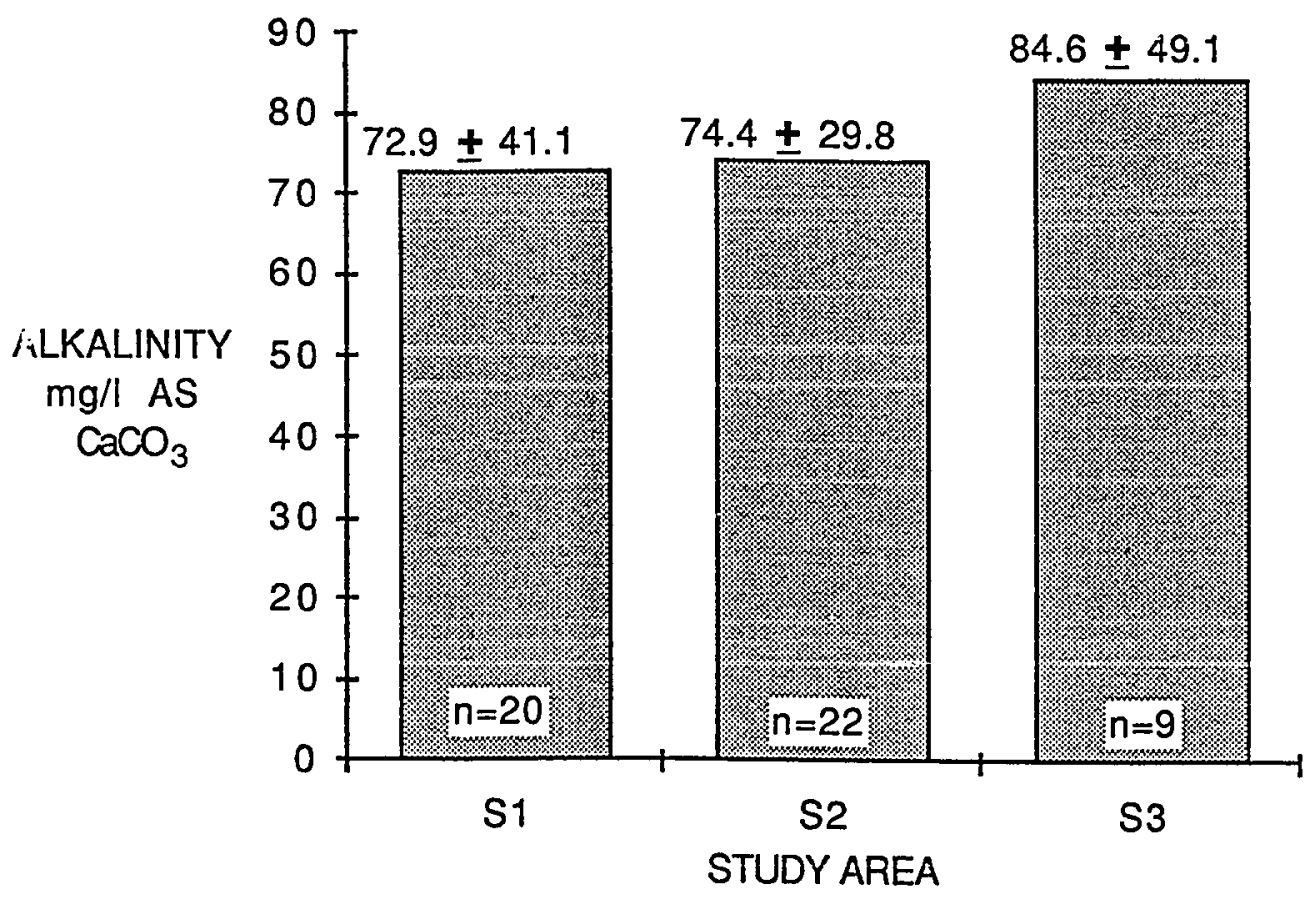

Figure 17. Average alkalinity for well samples from each study area. 
0.64 millimoles/liter. (figure 18). The DIC concentration ranges for Study Area I, Study Area II, and Study Area III are 0 to 3.8 millimoles/liter, 0.71 to 4.64 millimoles/liter, and 1.4 to 6.13 millimoles/liter, respectively.

Electrical Conductivity

Electrical conductivity values reveal the relative salinity of the groundwater. For the groundwater in the Tomales Bay watershed, Study Areas I and III had similar conductivities, $298.5 \pm 94.9 \mathrm{mhos} / \mathrm{cm}$ and 386.0 $\pm 152.0 \mathrm{mhos} / \mathrm{cm}$ respectively, while Study Area II had the highest, 598.0 $\pm 1530.0 \mathrm{mhos} / \mathrm{cm}$ (figure 19). The conductivity ranges for Study Area I, Study Area II, and Study Area III are 180 to $1,500 \mathrm{mhos} / \mathrm{cm}, 20$ to 18,000 mhos $/ \mathrm{cm}$, and 170 to $625 \mathrm{mhos} / \mathrm{cm}$, respectively.

Study Area Il's greater conductivity reflects the proximity of the sampled wells to the bay and also its small groundwater contribution to the bay, factors in increasing contamination by saltwater intrusion.

\section{Groundwater Nutrient Loading}

Nutrient loading rates were calculated by multiplying each study area's nutrient concentration by its discharge rate (table 12). The results of nutrient loading calculations show that Study Area III contributes the most nutrients to the bay. Study Area I contributes the next highest followed by Study Area II. Study Area III's nutrient contribution is so large due to high discharge rate and the abundance of nutrient sources. Study Area I contributes the next highest because its discharge rate is significantly larger than Study Area II's. Study Area II generally has higher groundwater nutrient concentrations than Study Area I but discharges a much smaller amount of water to Tomales Bay. 


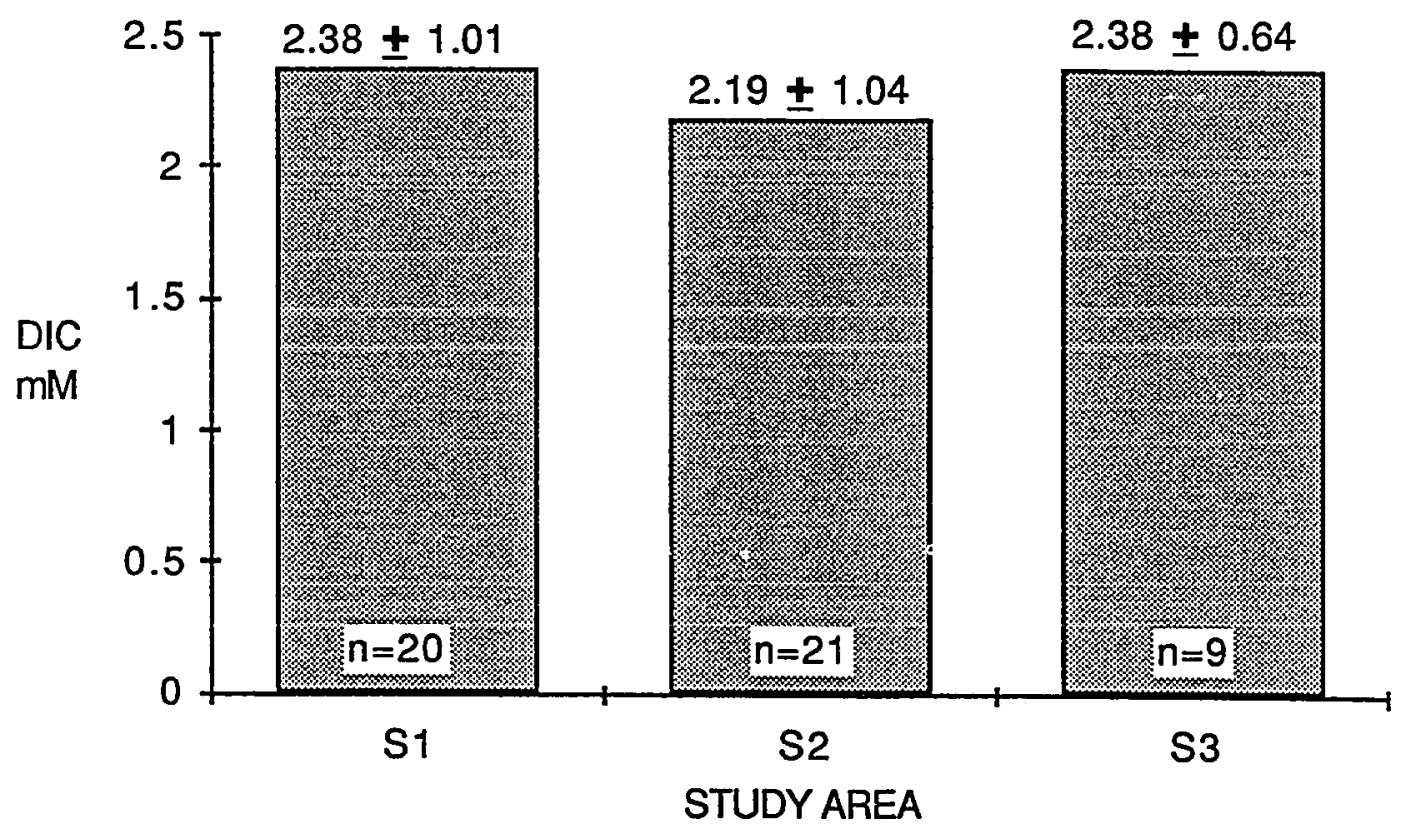

Figure 18. Average Dissolved Inorganic Carbon (DIC) concentrations for well samples each study area. 


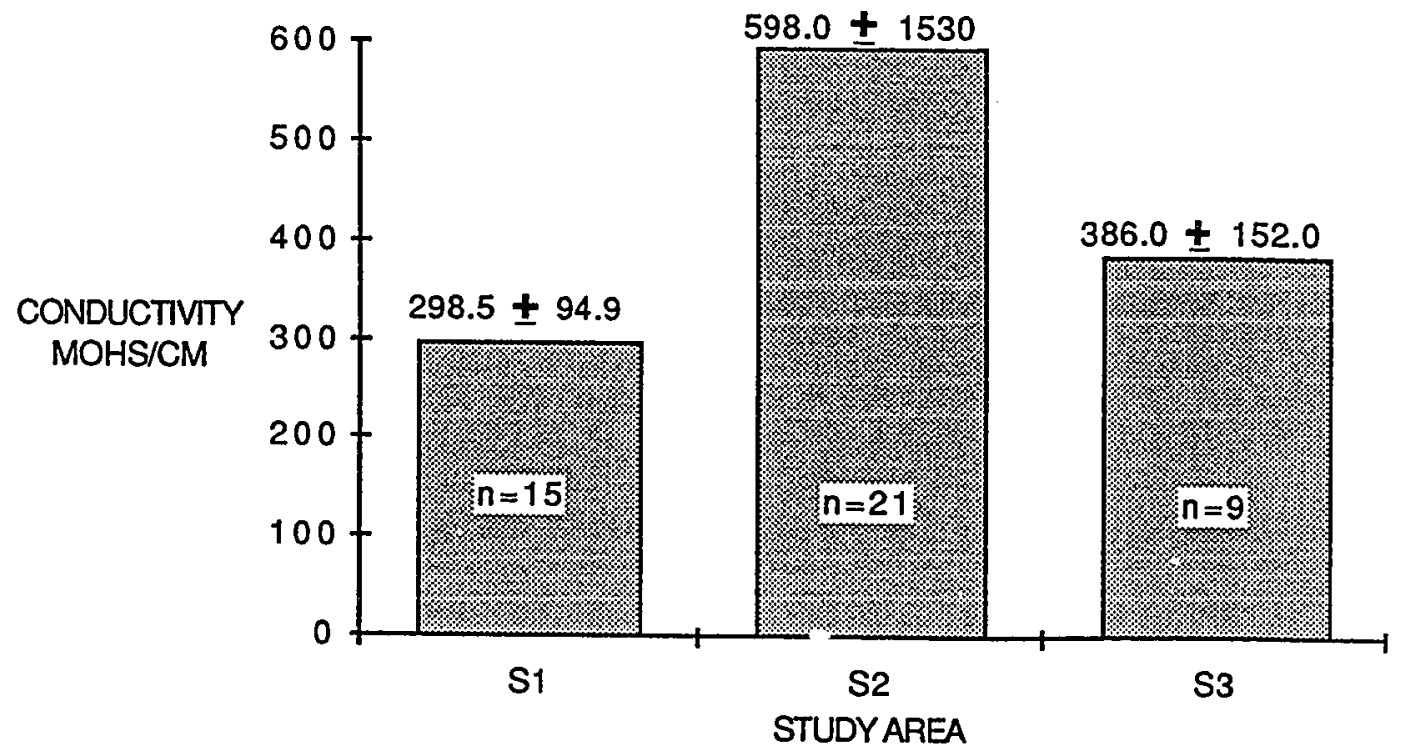

Figure 19. Average conductivity for well samples from each study area. 


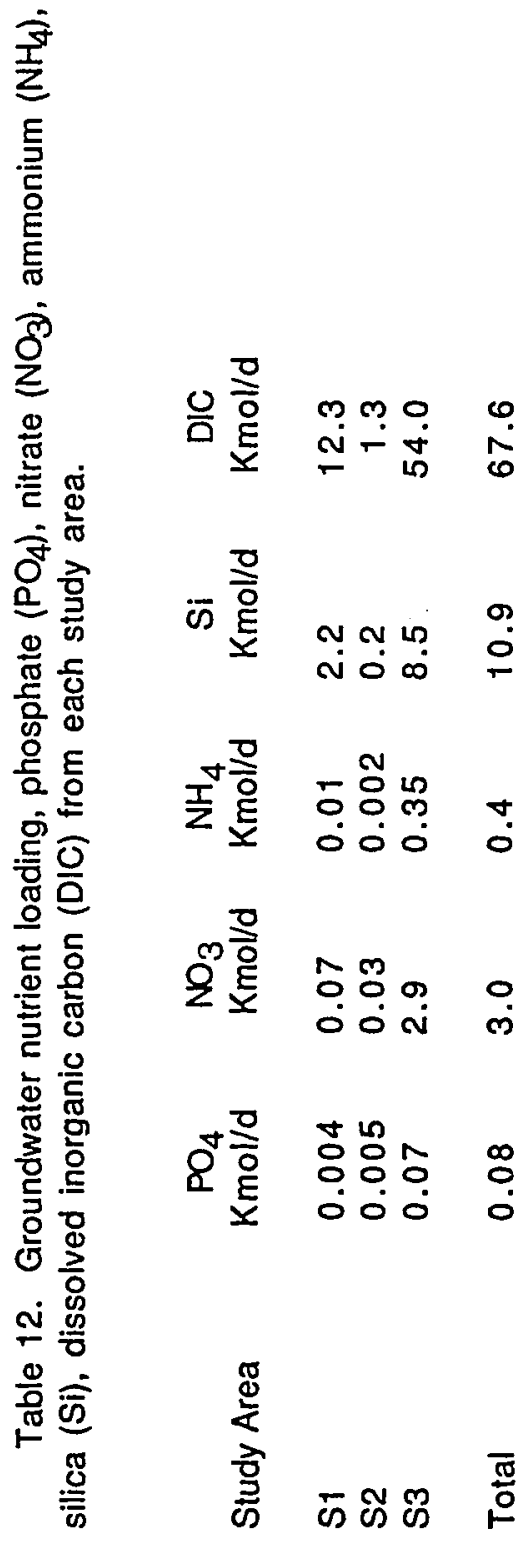




\section{CONCLUSIONS}

Groundwater is an important pathway for freshwater and nutrient loading to Tomales Bay during the summer months, when precipitation is negligible and stream input reduced. Stream freshwater and nutrient loading is the more dominant process during the rainy winter months. Groundwater is an important source of $\mathrm{NO}_{3}, \mathrm{NH}_{4}, \mathrm{Si}$ and DIC when compared to ocean advection, but is less important in terms of nutrient loading when compared to ocean mixing.

\section{Assessment of Freshwater Contribution}

Winter Period - November To March

Groundwater, in comparison to stream water and rainfall, contributes approximately $2 \%$ of the total winter freshwater budget to Tomales Bay (table 13 and figure 20). This value is relatively small compared to stream water, which contributes the largest percentage of freshwater to the bay, $90 \%$, and rainfall, which contributes $8 \%$.

\section{Summer Period - April To October}

During the summer period, groundwater contributes a significantly higher percentage of freshwater to Tomales Bay, $20 \%$, than was contributed in the winter period (table 13 and figure 20). Streams still, however, contribute the most freshwater to Tomales Bay, 68\%, while rainfall contributes $12 \%$. The streams included in the assessments are Lagunitas Creek, Walker Creek, Olema Creek, and minor streams (table 1) (Ken Markham, USGS, Santa Rosa, Personal communication with Stephen Smith, 1987). If Walker Creek were eliminated because it discharges so 
Table 13. Winter (Nov.-Mar.) and summer (Apr.-Oct.) freshwater contributions to Tomales Bay.

$\begin{array}{lrr}\text { Pathway } & \text { Winter } & \text { Summer } \\ \begin{array}{l}\text { Rainfall* } \\ 10^{4} \mathrm{~m}^{3} / \mathrm{d}\end{array} & 12.8 & 2.0 \\ \begin{array}{l}\text { Stream** } \\ 10^{4} \mathrm{~m}^{3} / \mathrm{d}\end{array} & 154.0 & 10.8 \\ \begin{array}{l}\text { Groundwater } \\ 10^{4} \mathrm{~m}^{3} / \mathrm{d}\end{array} & 2.9 & 2.9\end{array}$

*Rain gage data, Marin County Planning Dept., unpublished data.

**Stream gage data, October, 1974 to 1987 for Lagunitas Creek and

October, 1968 to 1987 for Walker Creek (Ken Markham, US Geological

Survey, Santa Rosa, personal communication with Stephen Smith, 1987).

Table 14. Calculated steady-state net fluxes (mol/d) of dissolved $\mathrm{PO}_{4}, \mathrm{NO}_{3}, \mathrm{NH}_{4}$, DIC, inner Tomales Bay, late summer, 1985, positive sign, net influx, negative sign, net outflux (Smith et al., 1987).

$\begin{array}{lrr}\text { Material } & \begin{array}{r}\text { Ocean } \\ \text { Advection }\end{array} & \begin{array}{r}\text { Ocean } \\ \text { Mixing }\end{array} \\ \mathrm{PO}_{4} & 29.2 & -2,032.5 \\ \mathrm{NO}_{3} & 66.4 & 5,155.4 \\ \mathrm{NH}_{4} & 61.3 & 1,820.8 \\ \mathrm{Si} & 368.1 & -4,673.4 \\ \mathrm{DIC} & 32.906 .0 & -26,994.0\end{array}$

Table 15. Average nutrient concentrations in stream water of the Tomales Bay watershed, June, 1987 through March, 1988, (Stephen Smith, unpublished data).

Season

Winter (Nov. - Mar.) 240.0

Summer (Apr. - Oct.) 240.0
$\mathrm{PO}_{4}$
$\mathrm{MM}$

0.6

0.6
$\mathrm{NO}_{3}$

MM

40.0

4.0

$\mathrm{NH}_{4}$ $M M$

DIC

$\mathrm{mM}$

$0.6 \quad 2.2$

$0.6 \quad 2.2$




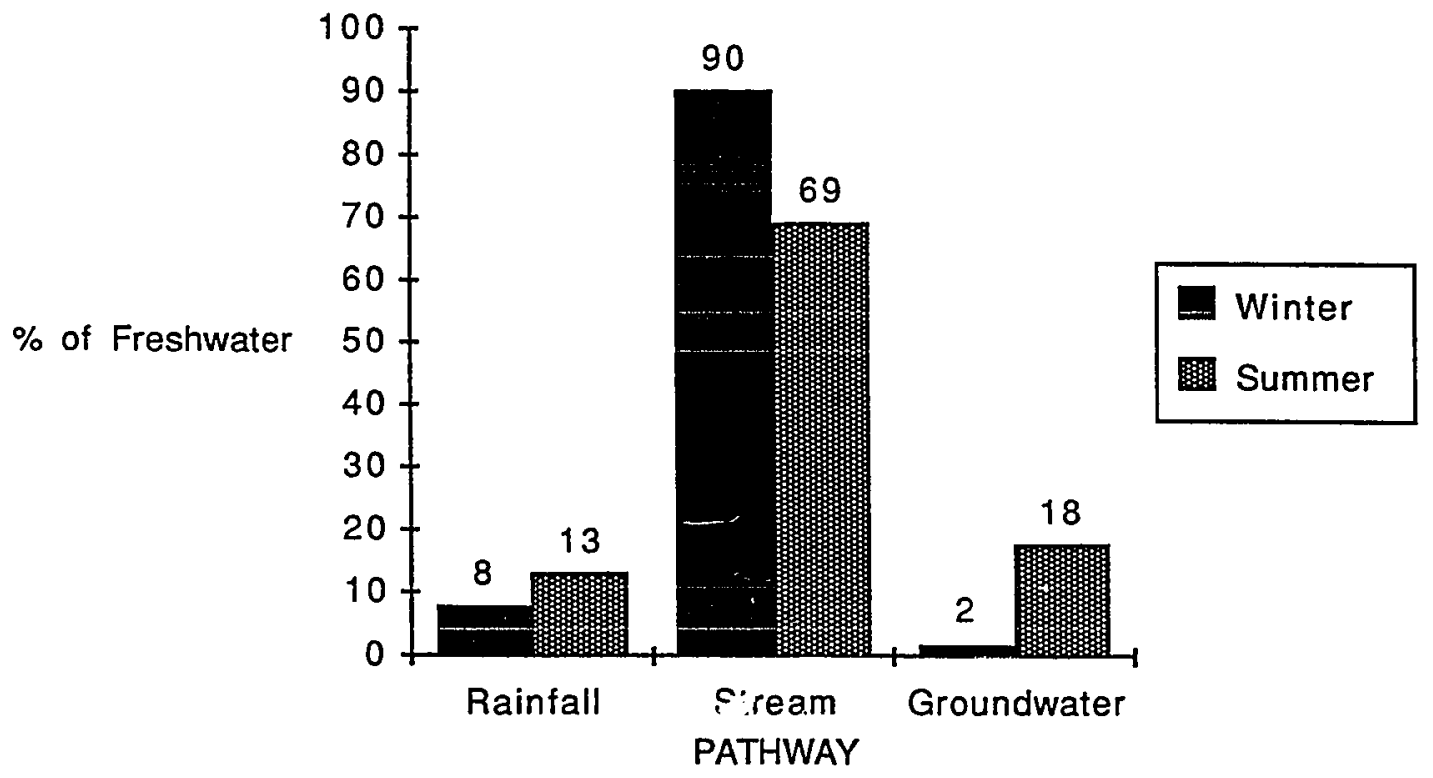

Figure ?0. A comparison of rainfall, stream, and groundwater freshwater inputs to Tomales Bay. 
near to ocean flushing, groundwater nutrient and freshwater loading would increase in their proportional significance. Rainfall was calculated by first, averaging monthly rainfall between Inverness and Pt. Reyes Station. This gives a monthly rainfall average for the southern bay. Then, the Inverness-Pt. Reyes Station average was averaged with monthly rainfall data from the Tomales station in the northern end of the bay to give a monthly precipitation averages from Tomales Bay. The surface area of the bay was taken to be $28 \mathrm{Km}^{2}$.

Significance of Freshwater Discharge

This study indicates that groundwater plays an important role in contributing freshwater to Tomales Bay especially during the summer period. A comparison of evaporation rates from the bay to the groundwater discharge rate shows that evaporation removes $4.5 \times 10^{4} \mathrm{~m} 3 / \mathrm{d}$ (Smith et al., 1987) in the months of September to October as compared to $2.9 \times 10^{4}$ $\mathrm{m}^{3} / \mathrm{d}$ for groundwater input. The significance of this is that evaporation plays a larger role in removing freshwater from Tomales Bay during the months of September and October than groundwater does in adding it. Groundwater discharge rates are assumed to be seasonally constant for this thesis since groundwater discharge does not change drastically between summer and winter and because no seaonal data were available.

\section{Assessment of Nutrient Loading}

The major pathways of nutrient loading included in this thesis are surface water, groundwater, ocean advection and ocean mixing. Rainfall nutrient loading is not included because no data were available for the nutrient contribution (primarily DIC) of rainfall to Tomales Bay. Ocean 
advection is the process by which nutrients are exchanged in the system by advective inflow in response to water depletion in the bay (by high evaporation) or advective outflow in response to excess water in the bay from freshwater inputs. Ocean mixing is the process by which nutrients are exchanged in the system by wind, tide and current induced mixing. Limited data in terms of ocean advection and mixing for the period of late summer, 1985 (Smith, et al., 1987) are presented in table 14. A positive sign in table 14 denotes the addition of nutrients to the system and a negative sign denotes the removal of nutrients from the system.

Phosphate, ammonium, silica, and dissolved inorganic carbon concentrations, not loading, remained fairly constant between the summer and winter periods for both groundwater and streams. Table 15 contains the stream water nutrient concentration data (Stephen Smith, unpublished data). The stream nitrate concentration drastically changed between winter and summer causing the nutrient loading results to drop significantly between winter and summer. The winter rise in nitrate concentration is probably due to rainy season runoff and the lower winter biological activity, reducing the denitrification process. As previously stated, because it was impossible to assess seasonal groundwater discharge rates, the groundwater discharge rates were assumed to be constant throughout the year.

Winter Period - November To March

Winter groundwater nutrient loading, as opposed to stream nutrient loading, is an important source of ammonium $\left(\mathrm{NH}_{4}\right)$ (table 16a and figure 21). Groundwater contributes a significantly smaller percentage of phosphate $\left(\mathrm{PO}_{4}\right)$, nitrate $\left(\mathrm{NO}_{3}\right)$, silica $(\mathrm{Si})$, and dissolved inorganic carbon (DIC). 
Table 16a. Winter (Nov.-Mar.) groundwater and stream nutrient loading to Tomales Bay. Stream gage data, October, 1974 to 1987 for Lagunitas Creek and October, 1968 to 1987 for Walker Creek (Ken Markham, US Geological Survey, Santa Rosa, personal communication with Stephen Smith, 1987)

$\begin{array}{lrc}\text { Nutrient } & \begin{array}{r}\text { Stream } \\ \text { Kmol/d }\end{array} & \begin{array}{l}\text { Groundwater } \\ \text { Kmol/d }\end{array} \\ \mathrm{PO}_{4} & 0.93 & 0.08 \\ \mathrm{NO}_{3} & 62.0 & 3.0 \\ \mathrm{NH}_{4} & 0.9 & 0.4 \\ \mathrm{Si} & 370.0 & 10.9 \\ \mathrm{DIC} & 3380.0 & 67.6\end{array}$

Table 16b. Summer (Apr.-Oct.) groundwater and stream nutrient loading to Tomales Bay. Stream gage data, October, 1974 to 1987 for Lagunitas Creek and October, 1968 to 1987 for Walker Creek (Ken Markham, US Geological Survey, Santa Rosa, personal communication with Stephen Smith, 1987)

$\begin{array}{lcc}\text { Nutrient } & \begin{array}{c}\text { Stream } \\ \text { Kmol/d }\end{array} & \begin{array}{l}\text { Groundwater } \\ \text { Kmol/d }\end{array} \\ \mathrm{PO}_{4} & 0.06 & 0.08 \\ \mathrm{NO}_{3} & 0.4 & 3.0 \\ \mathrm{NH}_{4} & 0.06 & 0.4 \\ \mathrm{Si} & 26.0 & 10.9 \\ \mathrm{DIC} & 240.0 & 67.6\end{array}$




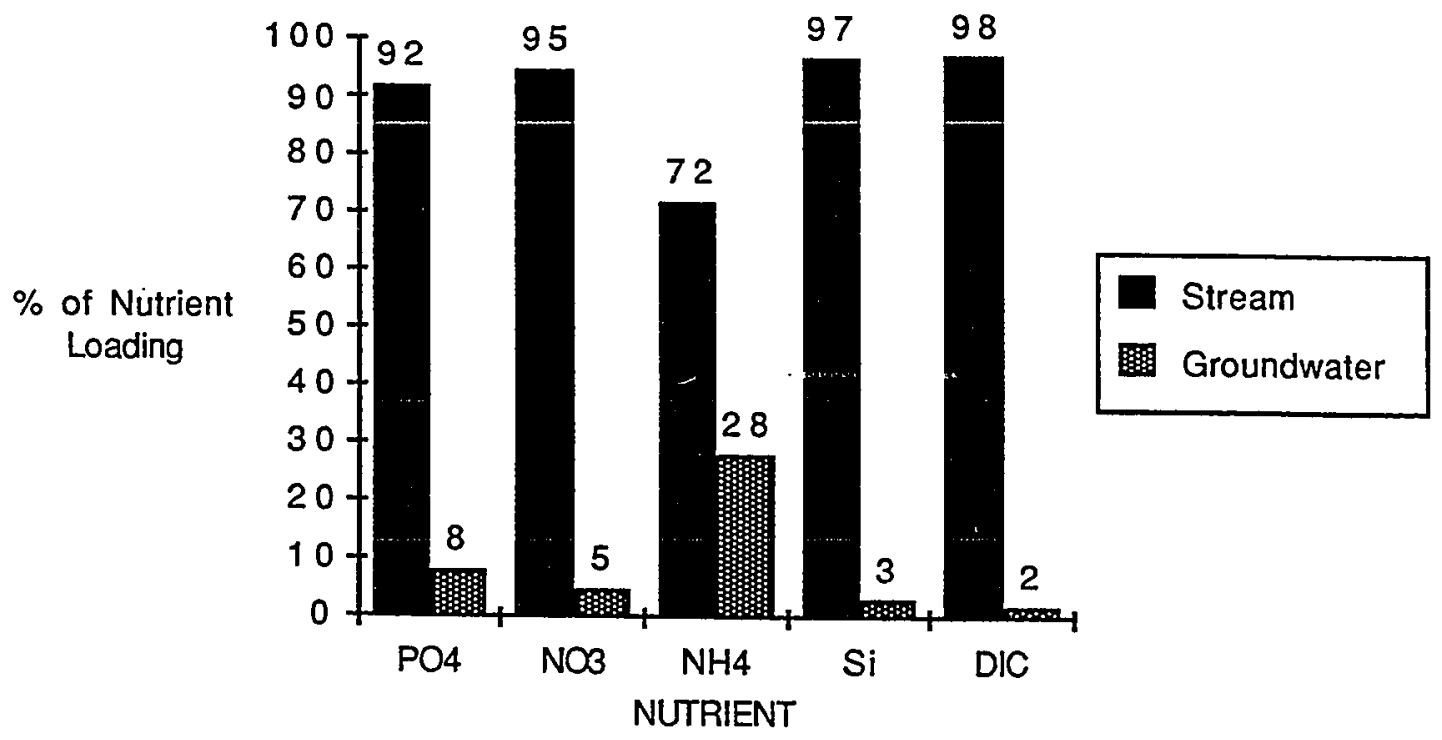

Figure 21. A comparison of groundwater and stream water winter nutrient loading to Tomales Bay.

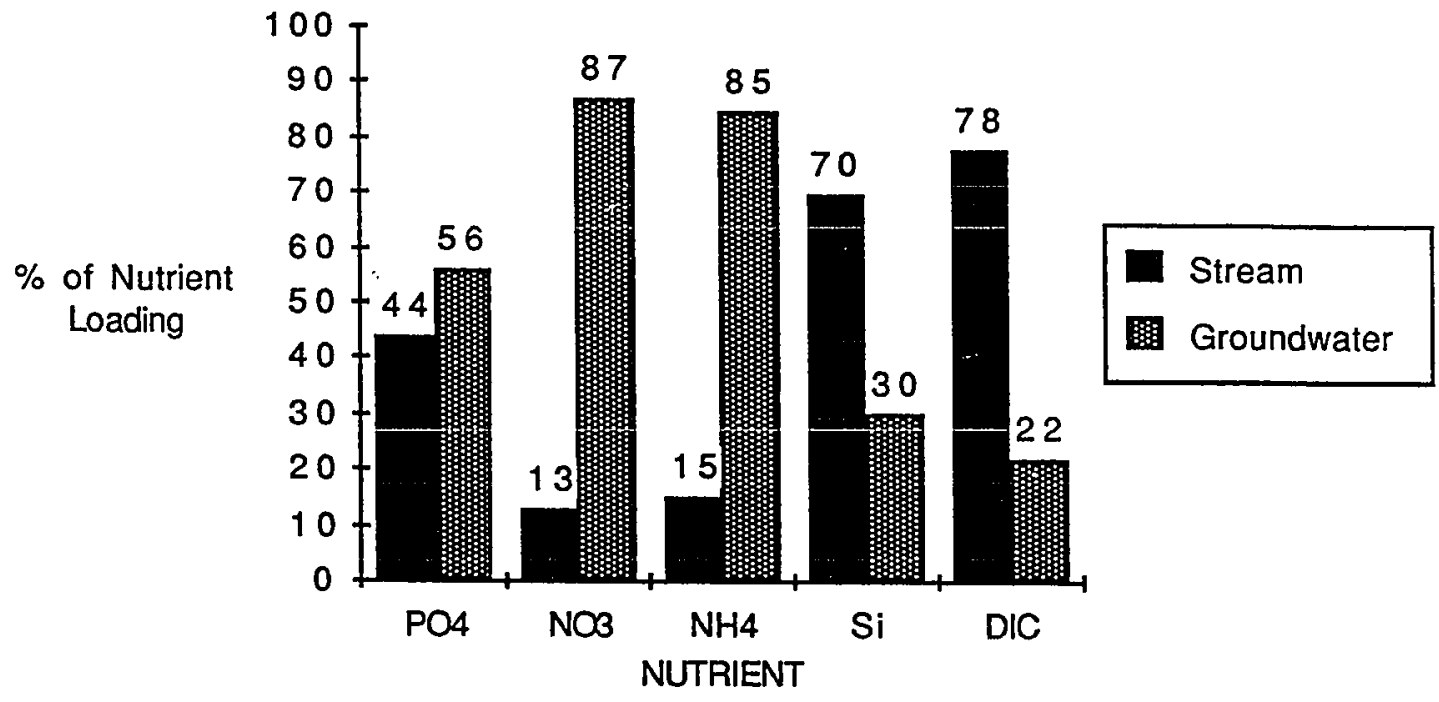

Figure 22. A comparison of groundwater and stream water summer nutrient loading to Tomales Bay. 


\section{Summer Period - April To October}

Summer groundwater nutrient loading of Tomales Bay, in comparison to stream nutrient loading, is significant (table $16 \mathrm{~b}$ and figure 22). This is due to the fact that little, if any, precipitation falls in the summer months, thus reducing runoff to the streams. Groundwater during this period contributes a larger percentage of phosphate, nitrate, and ammonium than streams. Groundwater also contibutes a significant portion of silica and dissolved inorganic carbon to Tomales Bay during the summer.

\section{Walker Creek}

In Smith et al. (1987), Walker Creek is excluded as a source for nutrient loading to Tomales Bay because it discharges so near to ocean flushing. This thesis included Walker Creek in the nutrient loading section since a total watershed contribution was used for the groundwater values. If Walker Creek were excluded from the nutrient loading comparison, the significance of groundwater nutrient loading would proportionately increase.

\section{Ocean Advection/Groundwater Comparison}

Groundwater as compared to ocean advection contributes significantly more $\mathrm{NO}_{3}, \mathrm{NH}_{4}$, and $\mathrm{Si}$ and slightly more DIC to Tomales Bay (figure 23). Ocean advection contributes more $\mathrm{PO}_{4}$ to the bay than groundwater.

Ocean Mixing/Groundwater Comparison

Groundwater as compared to ocean mixing composes the larger fraction of the total net flux of DIC and Si in and out of Tomales Bay, while ocean mixing composes the larger fraction of $\mathrm{PO}_{4}, \mathrm{NO}_{3}$, and $\mathrm{NH}_{4}$ (figure 24). 


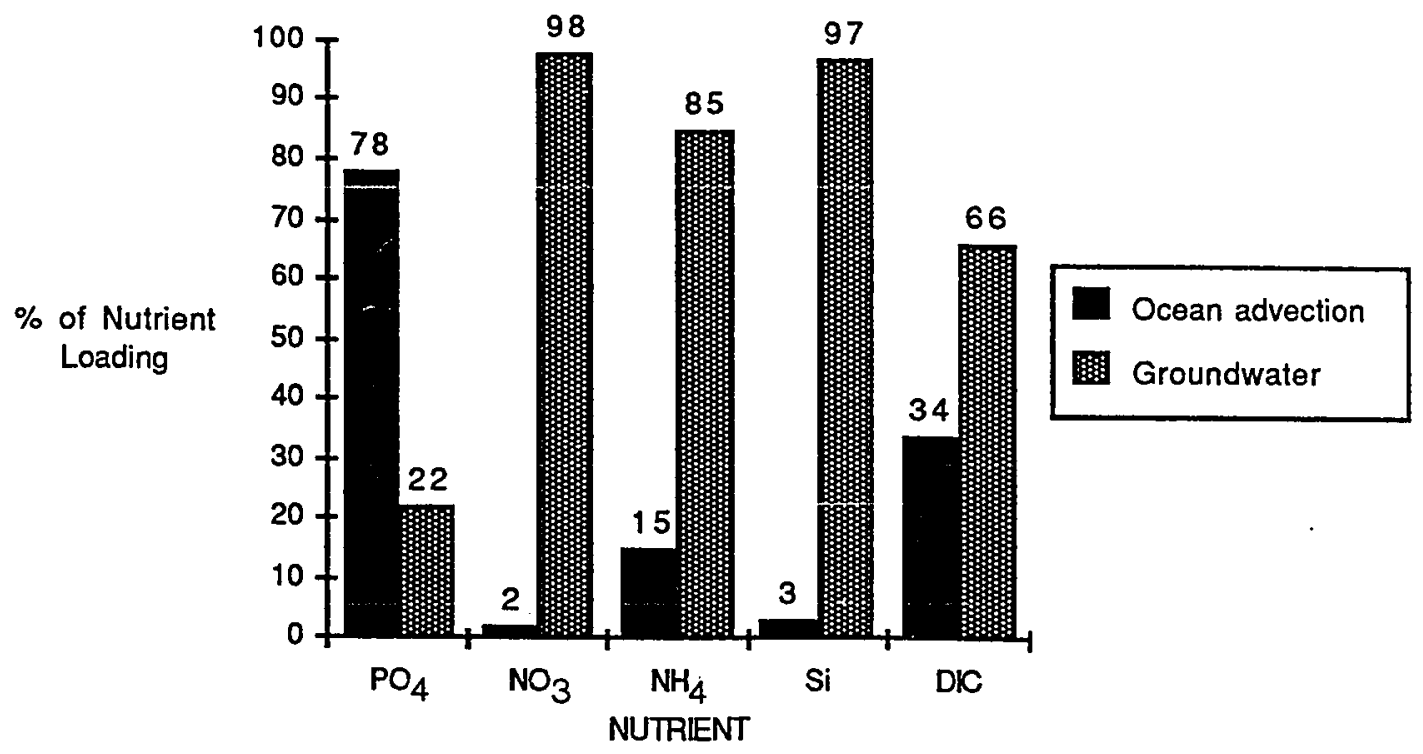

Figure 23. Groundwater nutrient loading compared to ocean advection nutrient loading to Tomales Bay.

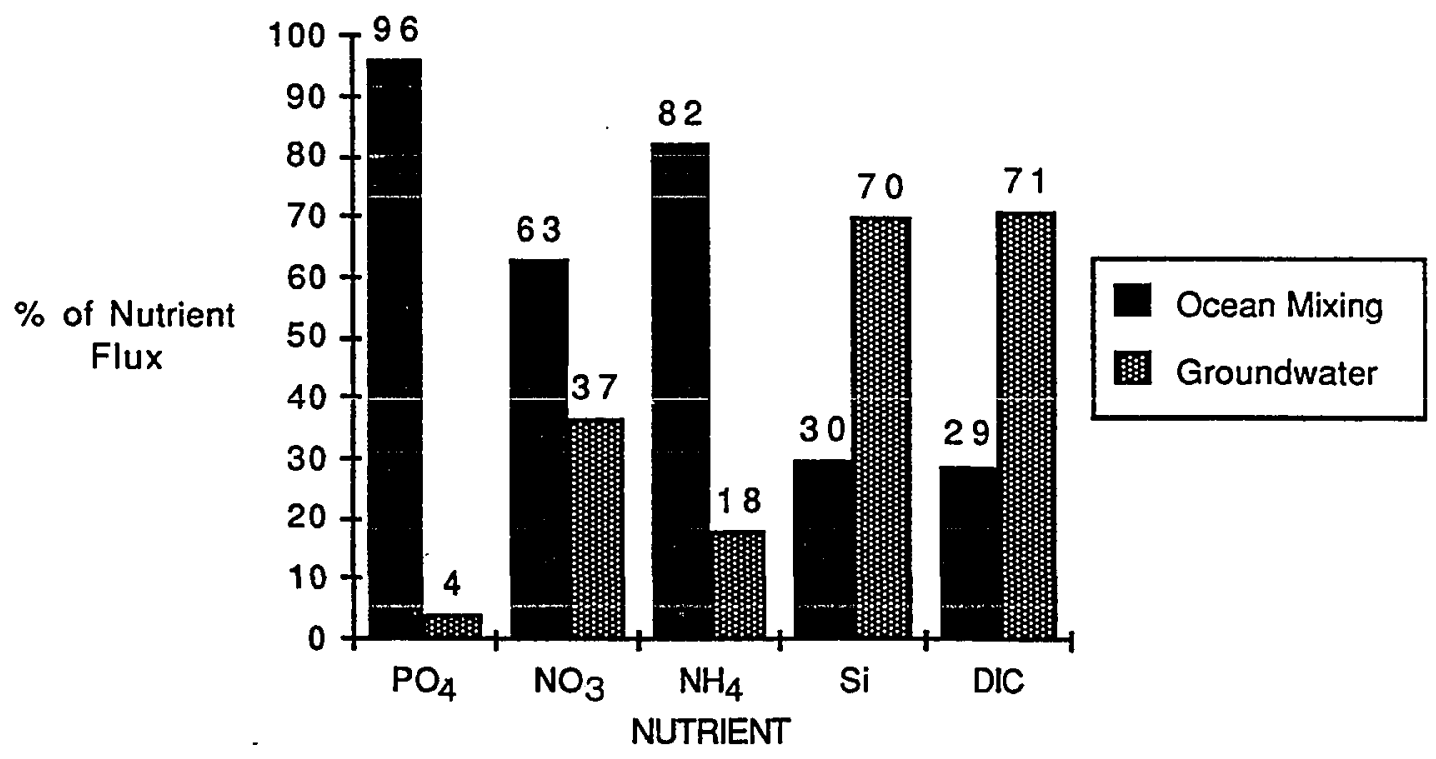

Figure 24. Groundwater nutrient flux compared to ocean mixing nutrient flux to Tomales Bay. 


\section{Future Studies}

\section{Seepage Flux Meters}

Since well water nutrient concentrations are potentially variable between the well sampling point and the discharge point, a future study of the groundwater nutrient and freshwater contribution to Tomales Bay might employ seepage meters (Lee, 1977). Lee (1977) proposed that "seepage flux can be measured and samples of groundwater flowing into lakes and estuaries collected by enclosing an area of bottom with a cylinder vented to a plastic bag." This method eliminates the need to measure permeability of sediments and yields a sample of water for chemical analysis (Lee, 1977). Figure 25 shows a typical seepage meter configuration.

One disadvantage of this method is that one would need to emplace an extensive array of seepage meters on the bottom of Tomales Bay in order to acquire accurate seepage fluxes and nutrient concentrations. Also seepage amounts and nutrient concentrations have been found to be variable over short distances, making it difficult to perceive trends in the data. In addition, seepage meters work best on sandy bottoms versus fine sediment bottoms, like Tomales Bay. The reason being that "groundwater flow may be too small to measure with a seepage meter or flow too restricted to distinct springs or leaks" (Le日, 1977).

\section{Detailed Testing and Monitoring}

Further future study would build upon what was accomplished by this thesis. A more extensive analysis of the watershed's aquifer permeabilities 


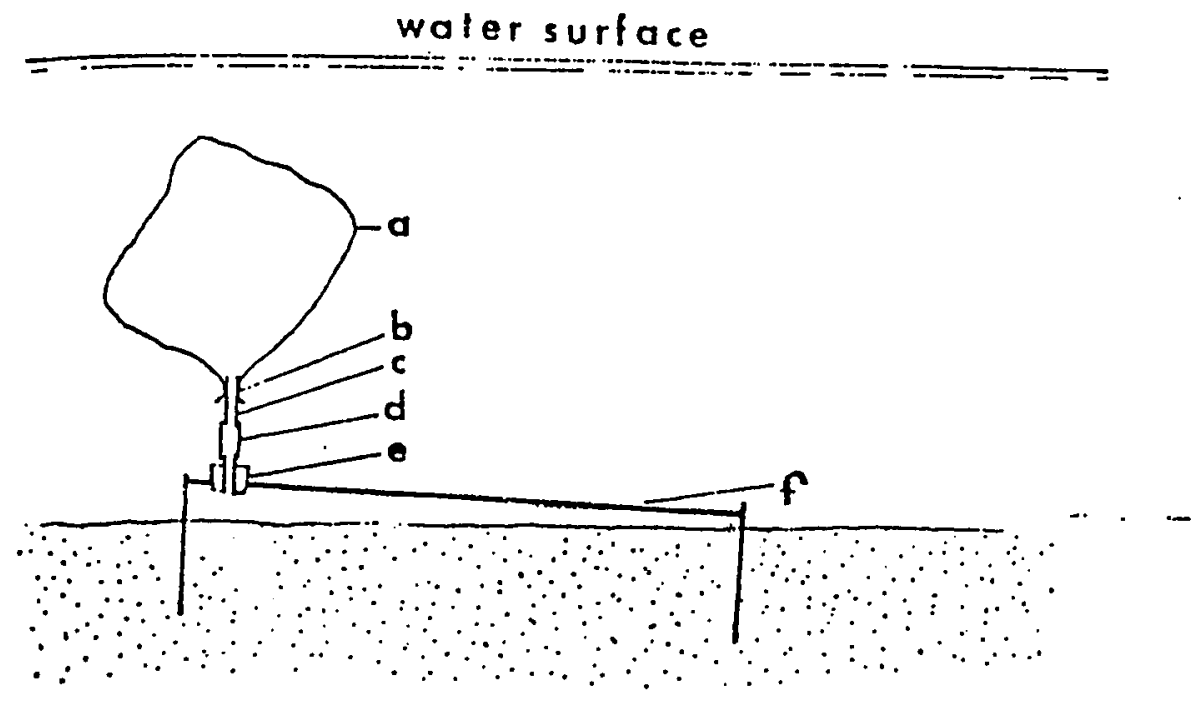

Figure 25. A diagram of a seepage meter. a) plastic bag; b) rubber-band wrap; c) polyethylene tube; d) amber-latex tube; e) rubber stopper with polyethylene tube; f) end section of a steel drum (Lee, 1977). 
and transmissivities would need to be performed. This could be accomplished by performing pump tests on as many wells in the Tomales Bay watershed as possible. More attention should be givento the San Andreas trough since it was found to have the highest nutrient concentrations and greatest groundwater potential. Also, a more extensive water level measuring project should be done in order to determine accurate hydraulic head gradients.

A sample program for nutrient concentrations in the wells should be arranged so groundwater nutrient concentrations could be monitored quarterly. One should sample during the summer months (dry period) and the winter months (wet period). The sample period for this thesis, June 1987 - March 1988, revealed little variability in nutrient concentrations between summer and winter months. The lack of any substantial winter rains in 1988 could have led to this lack of variability.

Geophysical surveys (seismic refraction and electrical resistivity) and borehole geophysics (spontaneous potential and resistivity logs) should be employed to gain more information concerning the groundwater's location and to increase the ability to target discharge zones. This is especially important in the Tomales Bay watershed because of the variable nature of aquifer location. This will also make it possible for the region's water districts to find suitable quantities of potable water to use in case of drought conditions. 


\section{REFERENCES}

Amstrong, F.A., Williams, P.M., Strickland, J.D.H., 1966, Photo-oxidation of organic matter in seawater by ultraviolet radiation, analytical and other applications: Nature, v. 211, p. 481-483.

Bailey, E.H., Irwin, W.P., and Jones, D.L., 1964, Franciscan and related rocks, and their significance in the geology of western California: California Division of Mines and Geology Bulletin 183, 177 p.

Bokniewicz, H., 1980, Groundwater seepage into Great South Bay, New York: Estuarine and Coastal Marine Science, v. 10, p. 437-444.

Brock, T.D., Lee, D.R., Janes, D. and Winek, D., 1982, Groundwater seepage as a nutrient source to a drainage lake: Lake Mendota, Wisconsin: Water resources, v. 16, p. 1255-1263.

California Department of Water Resources, 1978, Geology of the Inverness Ridge Study area: Inverness Public Utility District, $16 \mathrm{p}$.

Capone, D.G. and Bautista, M.F., 1985, A groundwater source of nitrate in nearhore marine sediments: Nature, v. 313, p. 214-216.

Collier, H.E., 1983, Supplemental water supply from wells for Inverness Public Utilities District, Marin County, California: Inverness Public Utilities District, $10 \mathrm{p}$.

Cooper Clark and Associates, 1978, Cumulative impact study of septic tank disposal systems in the Inverness area of Marin County: Marin County Department of Planning, $107 \mathrm{p}$.

Daetwyler, C.C. Jr., 1965, Marine geology of Tomales Bay, central California: Ph.D. thesis, University of California, San Diego, 169 p.

Dale, R.H., and Rantz, S.E., 1966, Hydrologic reconnaissance of Point Reyes National Seashore area, California: United States Geological Survey Open File Report 66-22, 36 p.

Freeze, Allan R. and Cherry, John A., 1979, Groundwater: Englewood Cliffs, New Jersey, Prentice Hall Inc., 604 p.

Galloway, A.J., 1966, Field trip to Point Reyes Peninsula and the San Andreas fault zone, in Bailey, E.H., editor, Geology of northern California: California Division of Mines and Geology Bulletin 190 , p. $429-440$. 
1977, Geology of the Point Reyes Peninsula, Marin County,

California: California Division of Mines and Geology Bulletin 202, 72 p.

Hall, N.T., and Hughes, D.A., 1980, Quaternary geology of the San Andreas Fault zone at Point Reyes National Seashore, Marin County, California in Streitz, R. and Sherburne, G., Editors, Studies of the San Andreas fault zone in northern California: California Division of Mines and Geology Special Report 140, p. 71-87.

Harding Lawson Associates, 1982, Geotechnical investigation of First Valley water treatment plant, Inverness water system, Inverness, California: inverness Public Utilities District, $20 \mathrm{p}$.

Lee, D.R., 1977, A device for measuring seepage flux in lakes and estuaries: Limnology and Oceanography, v. 22, p. 140-147.

Lewis, D., 1983, Geology, hydrology, and wells: Inverness Public Utilities District, $16 \mathrm{p}$.

Loeb, S.L. and Goldman, C.R., 1979, Water and nutrient transport via groundwater from Ward Valley into Lake Tahoe: Limnoiogy and Oceanography, v. 24, p. 1146-1154.

Marin County Planning Department, 1980, Marin County local coastal program unit 2: Marin County Planning Department, 217 p.

Mazella, A., 1983, Resistivity survey data, Inverness, California: Inverness Public Utilities District, $5 \mathrm{p}$.

North Marin County Water District, 1967, Water and sewage feasibility study: eastshore development Tomales Bay: North Marin County Water District, $23 \mathrm{p}$.

, 1969, Water and sewage feasibility study: Cypress Point development, Tomales Bay: North Marin County Water District, 23 p. $130 \mathrm{p}$.

1987, The summer dam; North Marin County Water District,

Oakeshott, G.B., 1966, San Andreas fault in California Coast Ranges

Province, in Bailey, E.H., editor, Geology of northern California: California Division of Mines and Geology Bulletin 190, p. 357-373.

Page, B.M., 1966, Geology of the Coast Ranges of California, in Bailey, E.H., editor, Geology of northern California: California Division of Mines and Geology Bulletin 190, p. 255-275. 
Pruitt, W.D., Fereres, E., Kaita, K., Snyder, R.L., 1987, Reference evapotranspiration (ETo) for California: Agricultural Experiment Station, Unversity of California Division of Agriculture and Natural Resources Bulletin 1922, 14 p.

Smith, S.V., Wiebe, W.J., Hollibaugh, J.T., Dollar, S.J., Hager, S.W., Cole, B.E., Tribble, G.W., Wheeler, P.A., 1987, Stoichiometry of C, N, P, and $\mathrm{Si}$ fluxes in a temperate-climate embayment: Journal of Marine Research, v. 45, p. 427-460.

Snyder, R.L., Pruitt, W.O., Shaw, D.A., 1987, Determining daily reference evapotranspiration (ETo): Cooperative Extension, University of California, Division of Agriculture and Natural Resources Leaflet 21426, $12 \mathrm{p}$.

United States Department of Agriculture, 1985, Soil survey of Marin County California: USDA, 229 p.

United States Geological Survey, 1976, Inverness Quadrangle Map, Marin County, California, 7.5 minute series (topographic).

Wagner, D.L., 1977, Geology for planning in western Marin County, California: California Division of Mines and Geology unpublished report, $42 \mathrm{p}$.

Wahrhaftig, C. and Wagner, J.R., 1972, Summary of the geologic report in Tomales Bay Environmental Study, p. 54-72.

Walton, W.C., 1970, Groundwater resource evaluation: New York, McGraw-Hill Book Company, 664 p. 
APPENDIX A

Generalized Soil Descriptions 


\section{DESCRIPTIONS OF GENERALIZED SOILS}

The United States Department of Agriculture published "The Soil Survey of Marin County, California" in 1985. A summary of the eight generalized soil types that exist in the Tomales Bay watershed is presented in this appendix. Plate 3 is a generalized soils map of the Tomales Bay watershed.

\section{Bulcher-Cole}

Bulcher-Cole soil is very deep, gently sloping, somewhat poorly drained soil and is found in basins and alluvial fans. Bulcher soils have a grayish, grayish brown silt loam surface layer underlain by gray, silty clay loam and clay loam. Cole soils have a gray, clay loam surface layer, underlain by dark gray and grayish brown silty clay.

Available water capacity is high and permeability is slow. The soils are wet and subject to flooding during the rainy season. Annual grasses are the predominant vegetation existing on this soil.

\section{Duneland-Sirdrak}

The Duneland-Sirdrak soil is very deep, gently sloping to steep, somewhat excessively drained, and is found on coastal dunes. Duneland is recent windblown deposits and supports little, if any, vegetation. Sirdrak soils are on stabilized dunes. The surface layer is very dark, grayish brown sand and is underlain by dark, yellowish brown to yellowish brown sand. These soils have a low available water holding capacity and are suited only to drought tolerint plants. 
Kehoe-Inverness-Sheridan Variant

These soils are moderately deep, strongly sloping to very steep, well-drained, and underlain by sandstone and quartz diorite. Kehoe and Sheridan Variant soils are dominant. Kehoe soils are very dark grayish brown loam.

The underlying material is very pale brown loam over weathered soft sandstone. Sheridan Variant soils have an underlying material that is brown coarse sand loam over weathered quartz diorite. Residential and agricultural use of this unit is limited by steepness of slope, depth to rock, hazard of erosion, and restricted available water holding capacity.

\section{Palomarin-Wittenberg}

This soil is found on hills and mountains, is deep, strongly sloping to very steep, and well drained. The surface layer of the Palomarin soil is dark grayish brown loam. The underijing material is grayish brown and brown loam over hard, highly fractured, siliceous shale and sandstone. The surface layer of the Wittenberg soil is dark grayish brown very gravelly loam. The underlying material is yellowish brown and brown, very gravelly loam, over hard, highly fractured, siliceous shale.

\section{Cronkite-Dipsea-Centissima}

The soil exists on uplands and is moderately deep to deep, strongly sloping to very steep, moderately well drained to well drained. The surface layer of the Cronkite soil is brown loam. The subsoil is yellowish brown and strong brown clay, underlain by weatherd sandstone and shale. The surface layer of the Dipsea soil is dark brown, very gravelly loam. The subsoil is b, own, very gravelly clay loam, underlain by weathored sandstone 
and shale. The surface layer of the Centissima soil is brown loam. The subsoil is light yellowish brown loam. The substratum is light brown gravelly clay loam over weathered sandstone and shale.

Olompali-Soulajoule-Felton Variant

This soil is present on terraces and uplands, is moderately deep and derp, gently sloping to very steep, and somewhat poorly drained to well drained. The surface layer of the Olompali soil is grayish brown loam. The upper part of the soil is yellowish brown and brown clay and the lower part is pale brown and light yellowish brown clay. The surface layer of the Soulajoule soil is reddish brown gravelly clay underlain by highly weathered sandstone. The surface layer of the Felton Variant soil is brown loam. The upper part of the subsoil is yellowish brown clay loam and the lower part is strong brown clay underlain soft weathered shale.

Tocaloma-Saurin

This soil is found on uplands and is moderately deep, gently sloping to very steep and well drained. The Tocaloma soil has a grayish brown loam surface layer. The subsoil is light yellowish brown, very gravelly loam over sandstone and shale. Saurin soils have a yellowish brown clay, very gravelly surface layer and subsoil underlain by sandstone. Most areas of this unit are used as rangeland.

\section{Los Osos-Bonnydoon}

This soil is found on uplands, shallow and moderately deep, gently sloping to very steep, well drained to somewhat excessively drained. The

surface layer of the Los Osos soil is grayish brown loam. The subsoil is brown clay underlain by fractured weathered shale and sandstone. 
Bonnydoon soils are shaliow and somewhat excessively drained. The surface layer is grayish brown gravelly loam underlain by fractured weathered sandstone. This unit is mainly used as rangeland. 


\section{APPENDIX B}

Monthly Evapotranspiration

Isoline Maps of California 


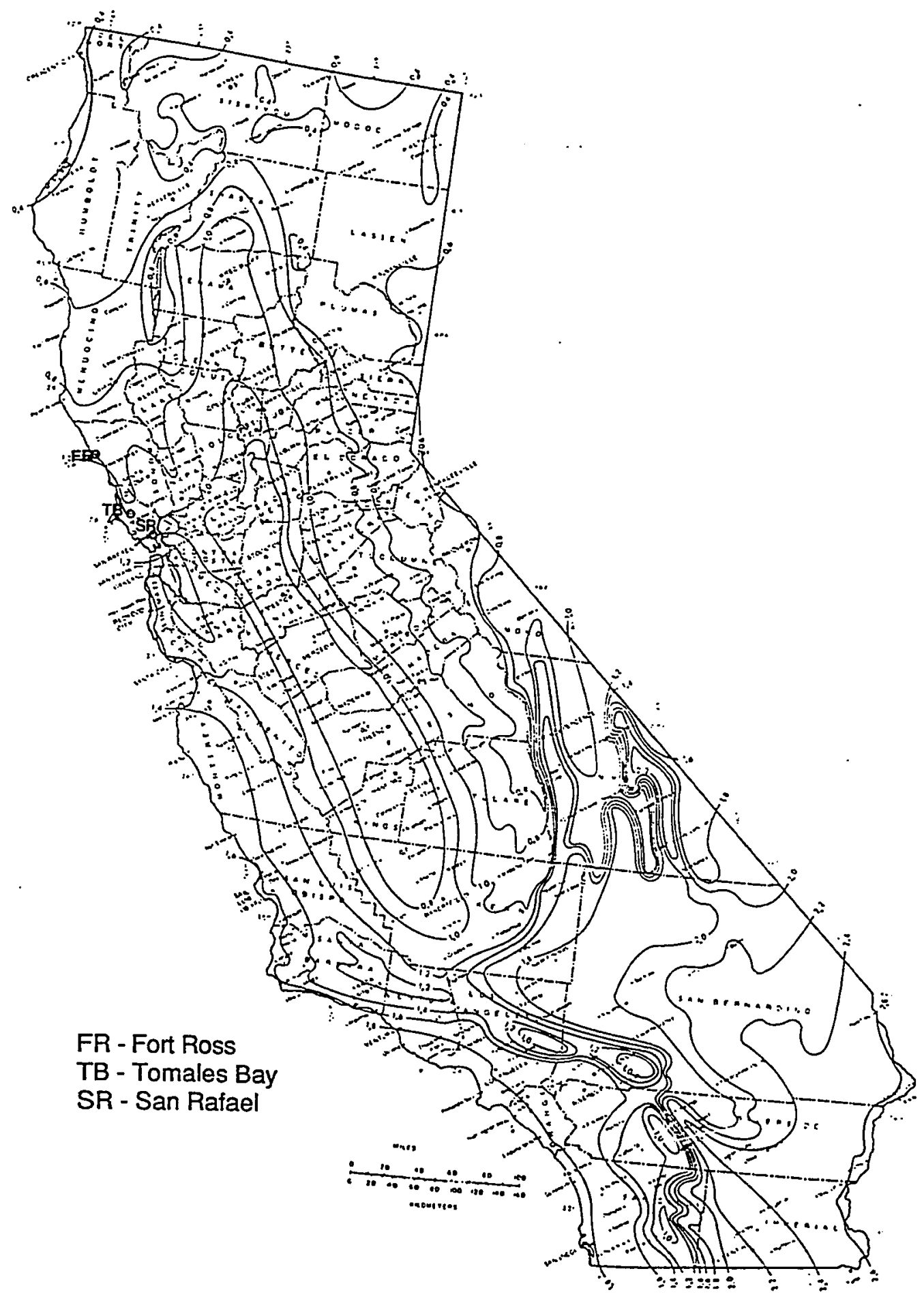

Figure 26. January reference evapotranspiration isoline map for California in mm per day (Snyder et al., 1987). 


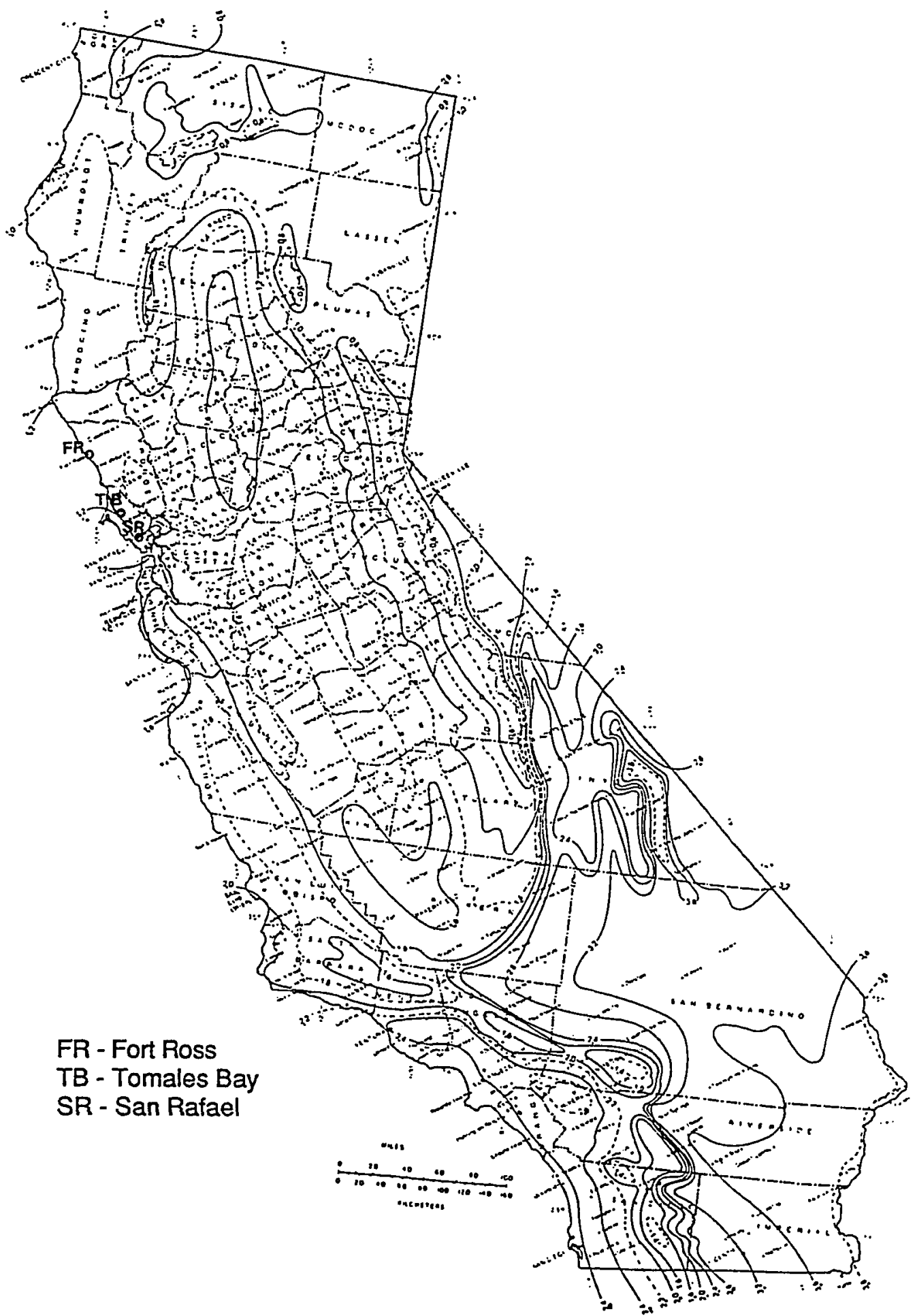

Figure 27. February reference evapotranspiration isoline map for California in $\mathrm{mm}$ per day (Snyder et al., 1987). 


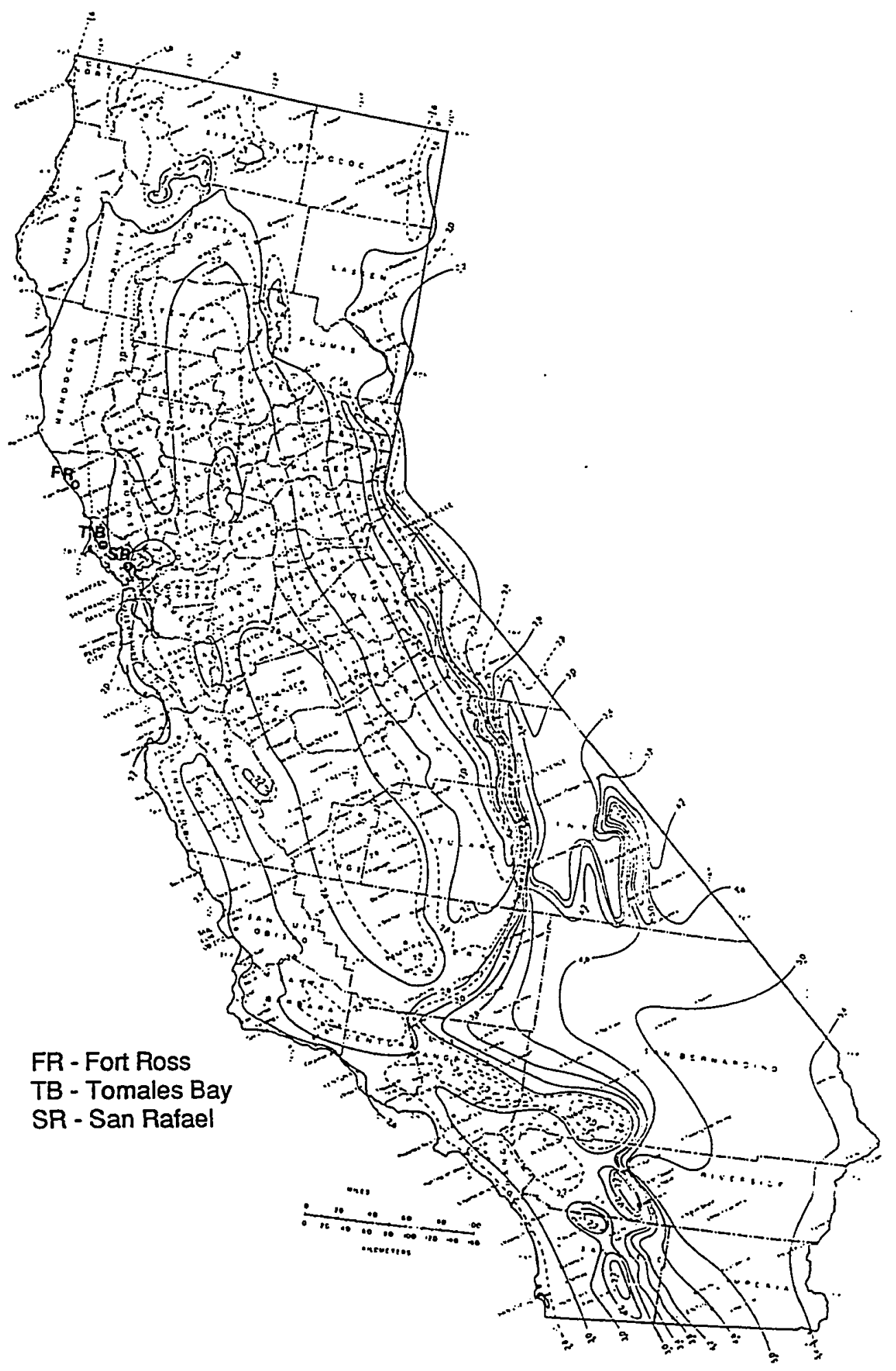

Figure 28. March reference evapotranspiration isoline map for California in $\mathrm{mm}$ per day (Snyder et al., 1987). 


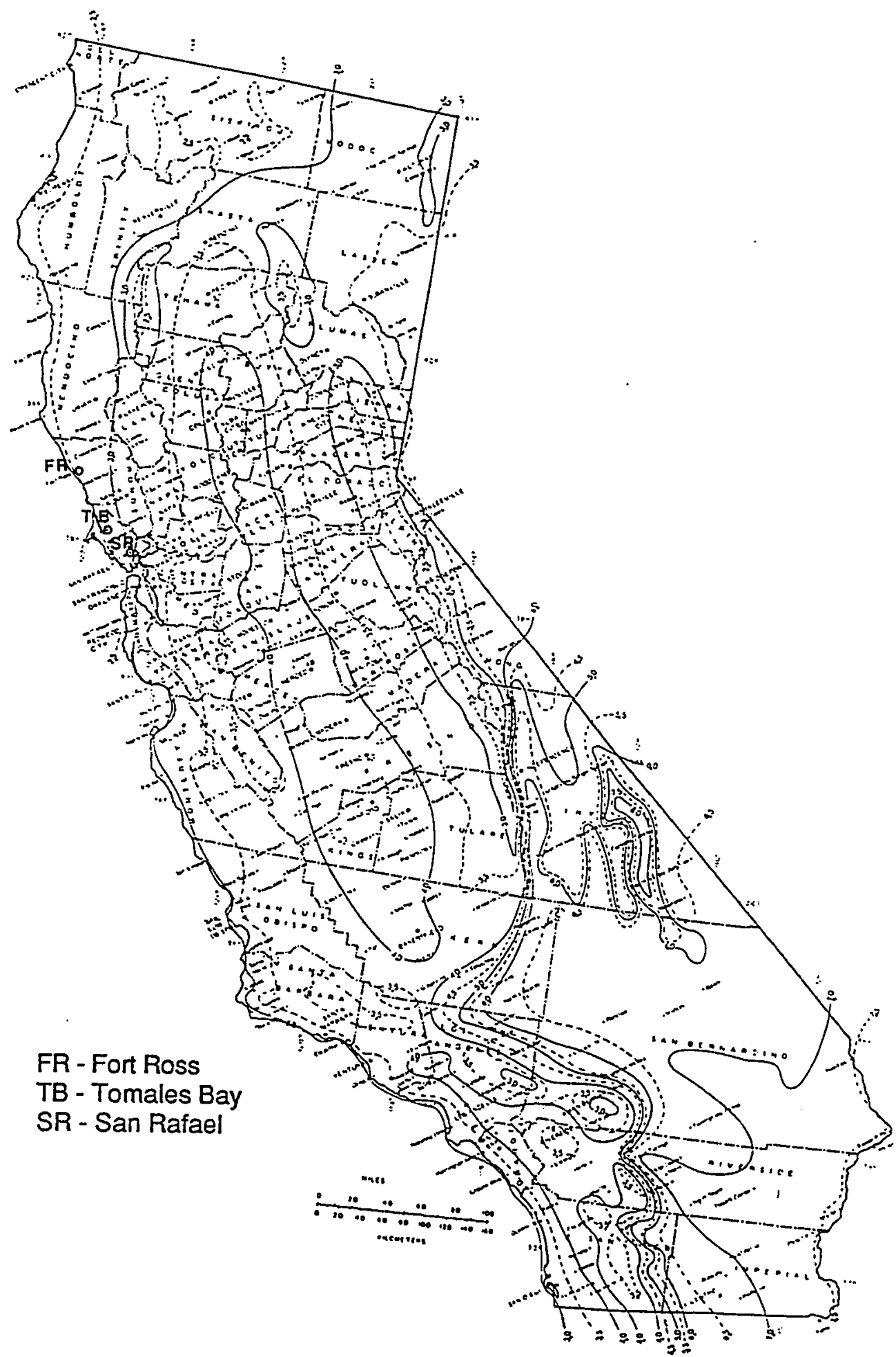

Figure 29. April reference evapotranspiration isoline map for California in $\mathrm{mm}$ per day (Snyder et al., 1987). 


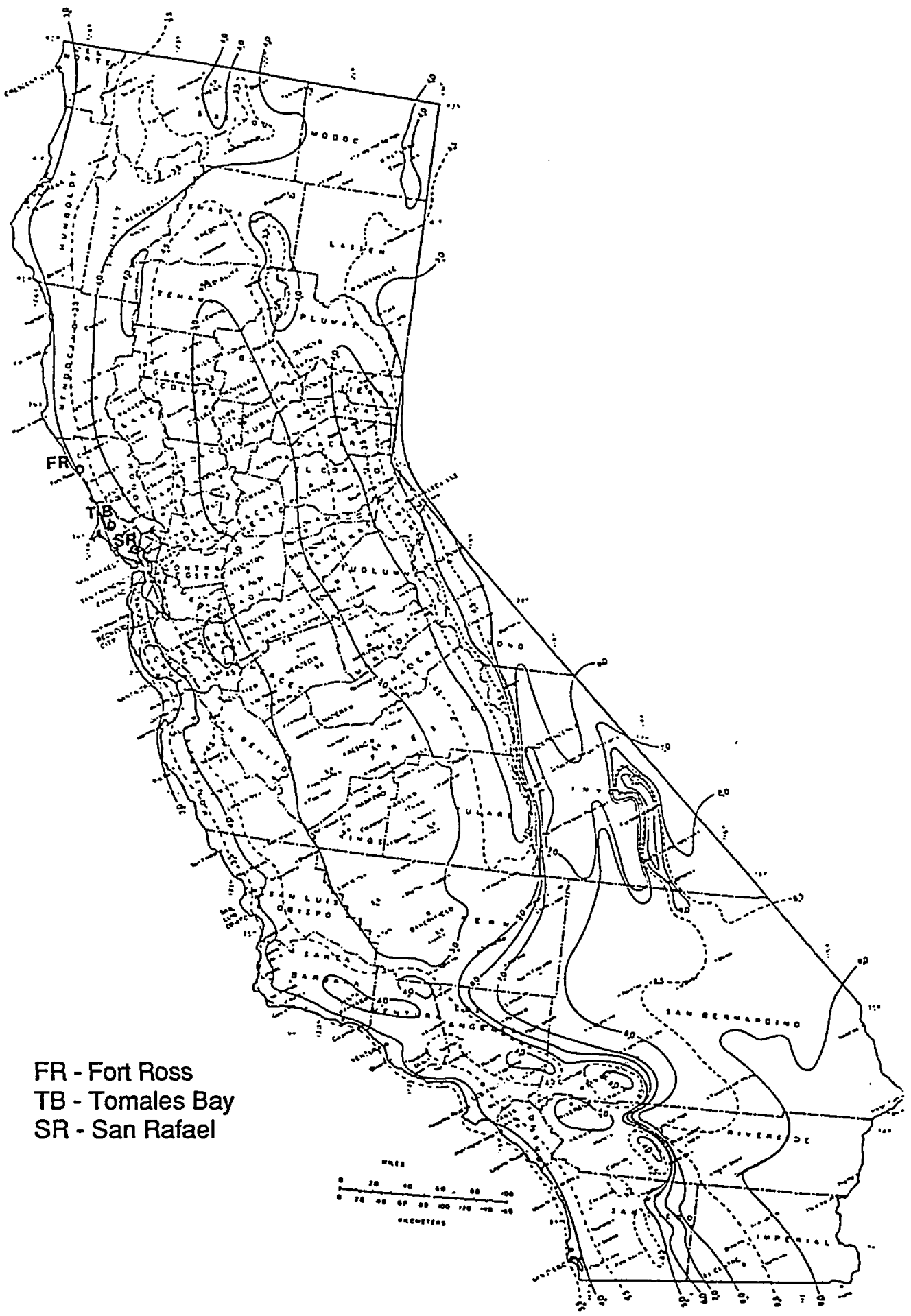

Figure 30. May referènce evapotranspiration isoline map for California in $\mathrm{mm}$ per day (Snyder et al., 1987). 


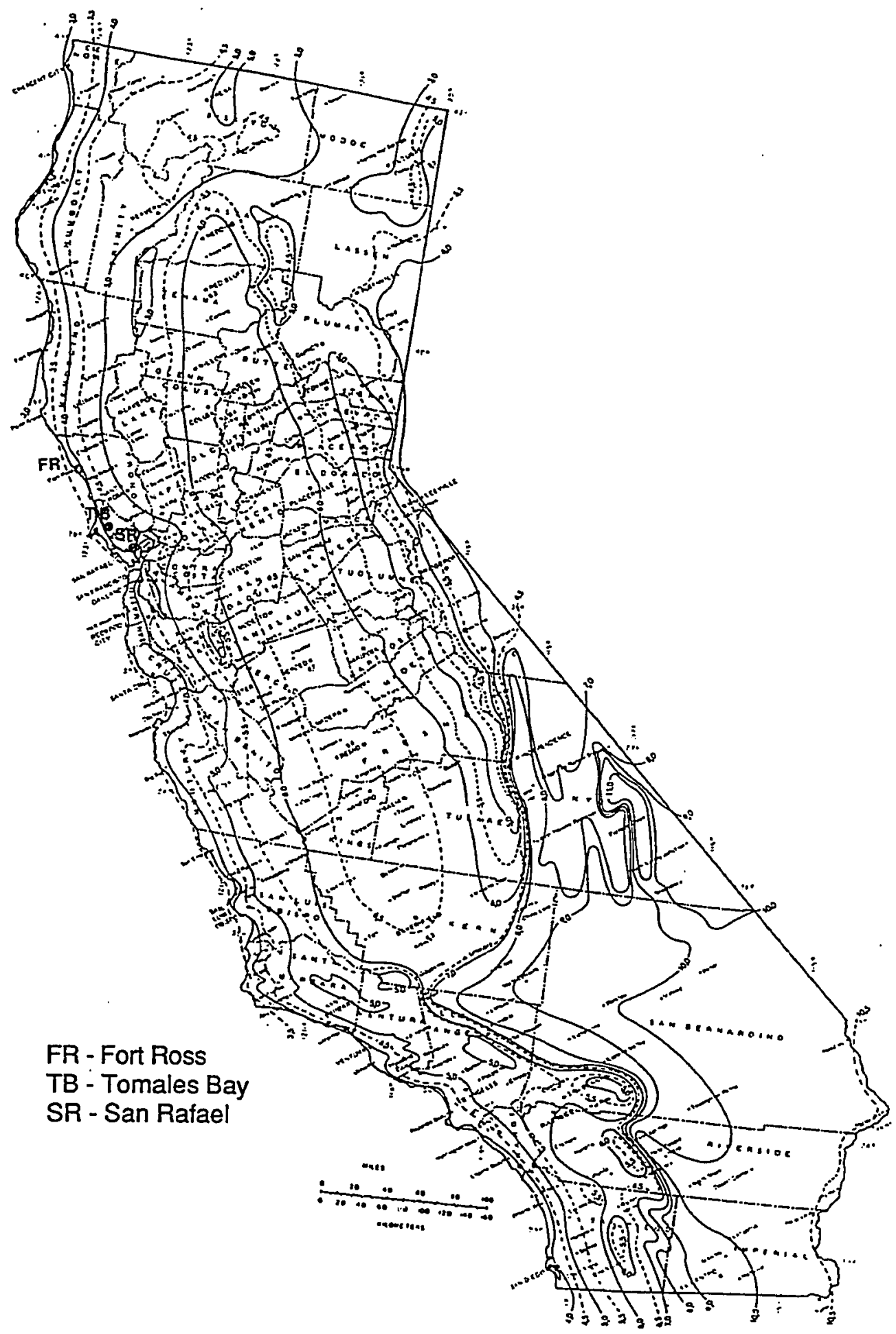

Figure 31. June reference evapotranspiration isoline map for California in $\mathrm{mm}$ per day (Snyder et al., 1987). 


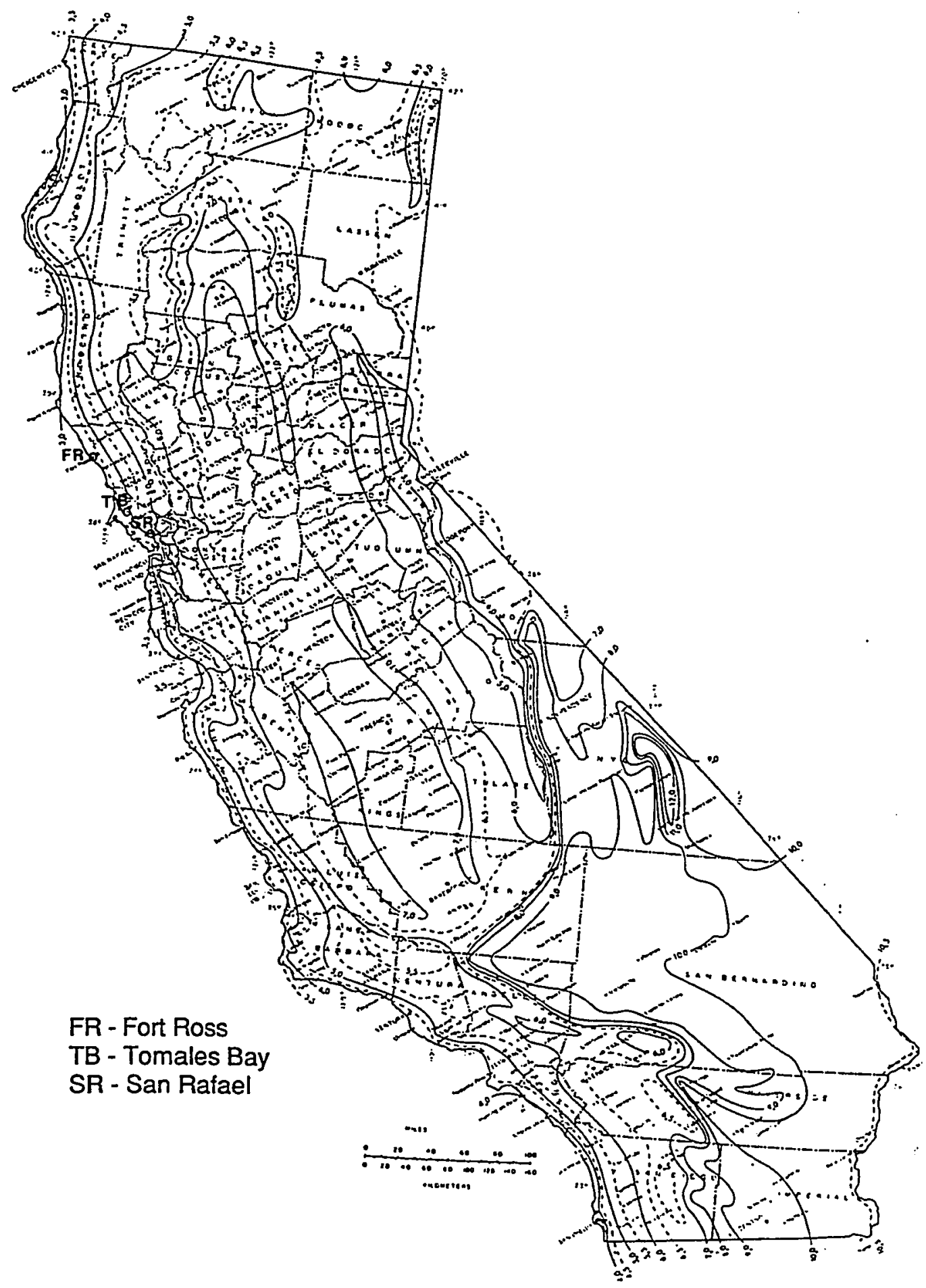

Figure 32. July reference evapotranspiration isoline map for California in $\mathrm{mm}$ per day (Snyder et al., 1987). 


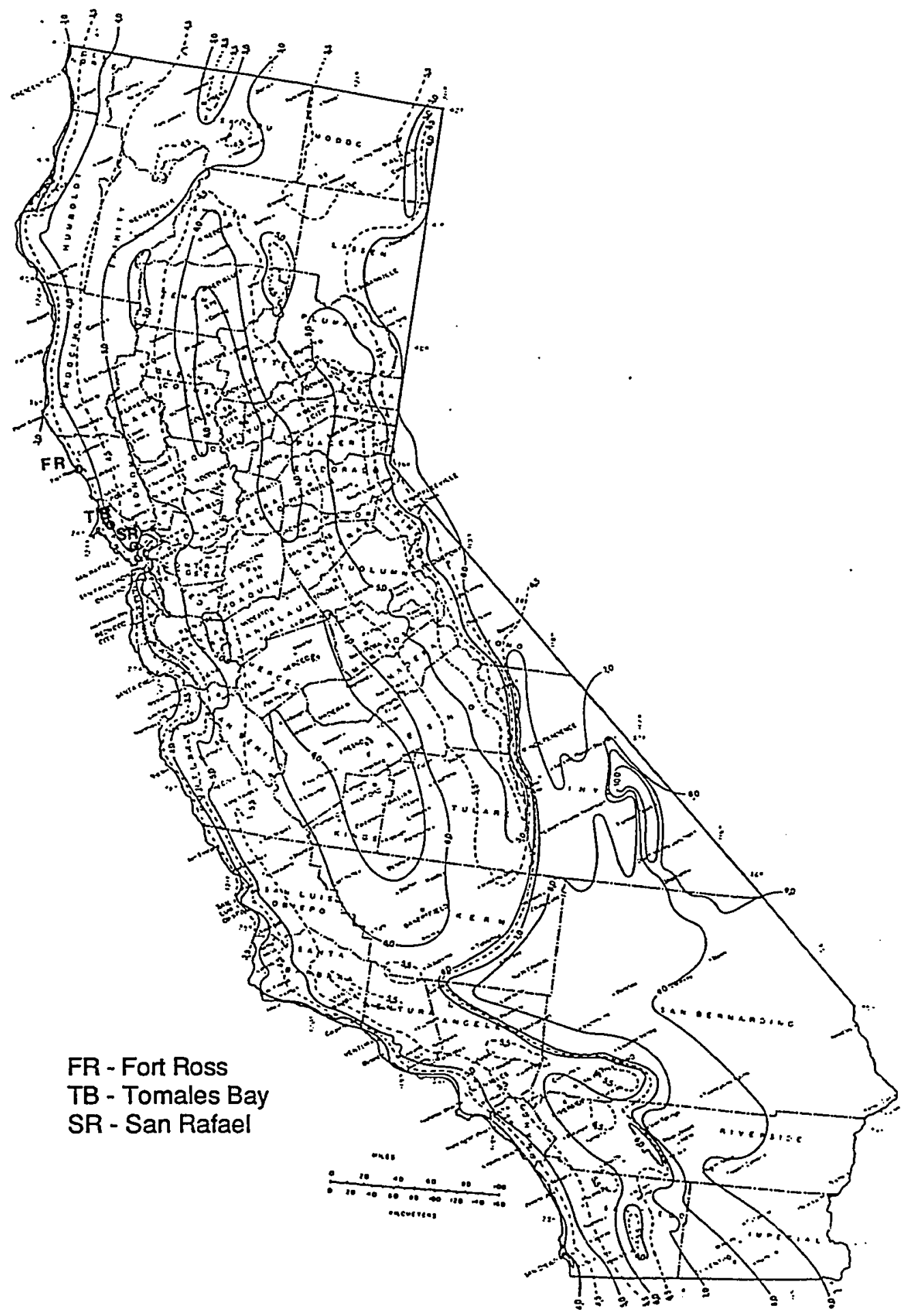

Figure 33. August reference evapotranspiration isoline map for California in $\mathrm{mm}$ per day (Snyder et al., 1987). 


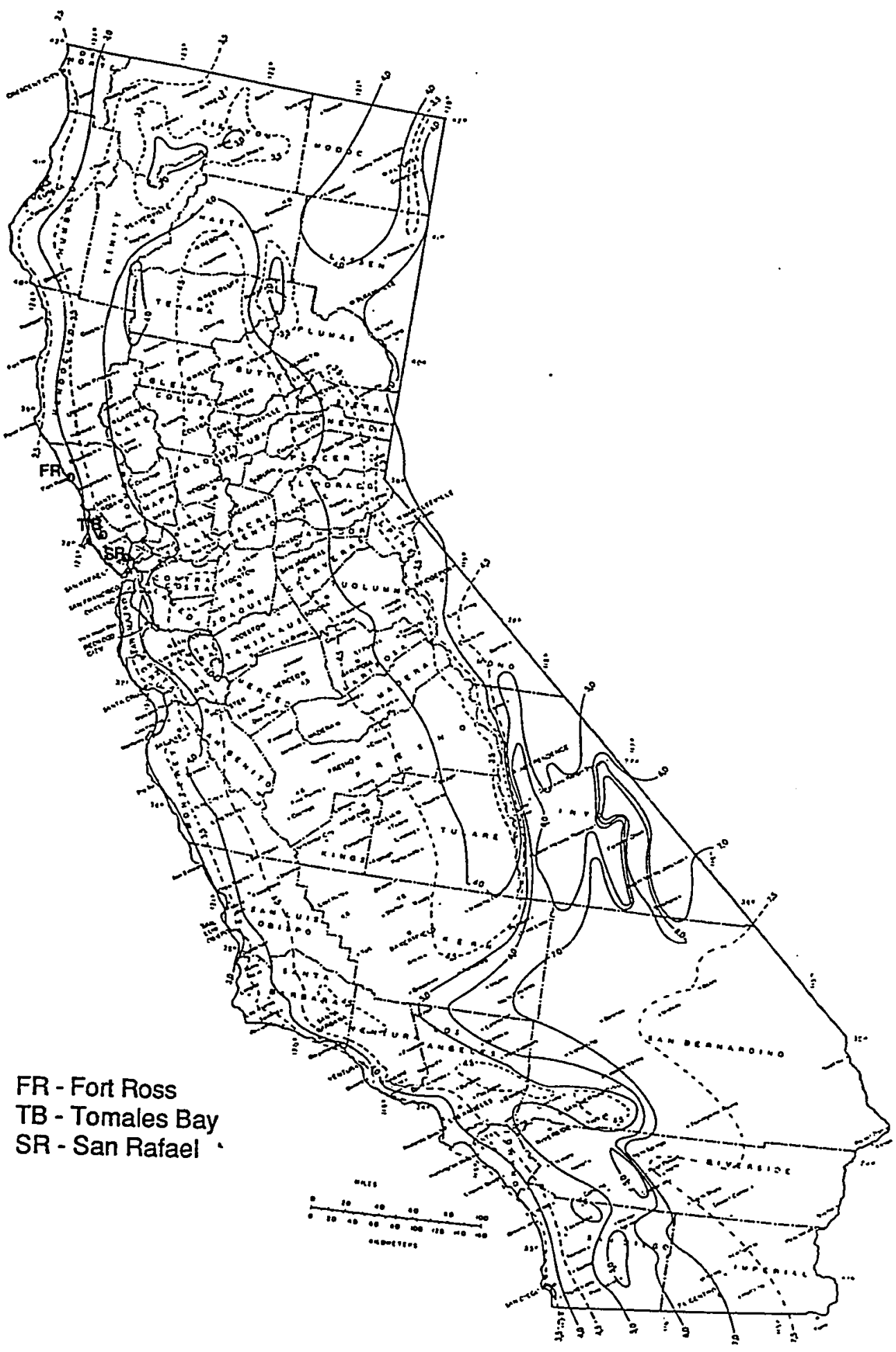

Figure 34. September reference evapotranspiration isoline map for California in mm per day (Snyder et al., 1987). 


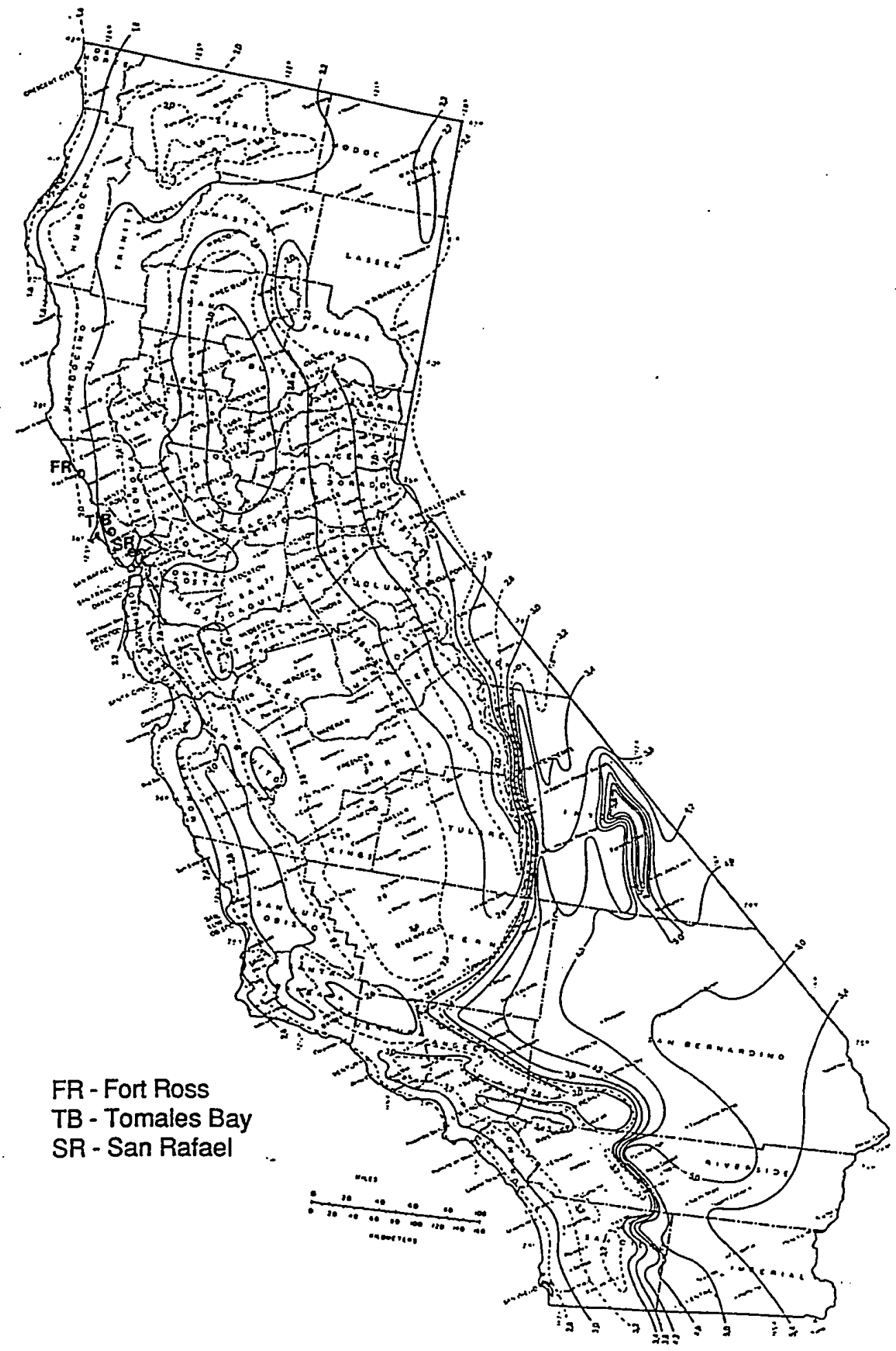

Figure 35. October reference evapotranspiration isoline map for California in $\mathrm{mm}$ per day (Snyder et al., 1987). 


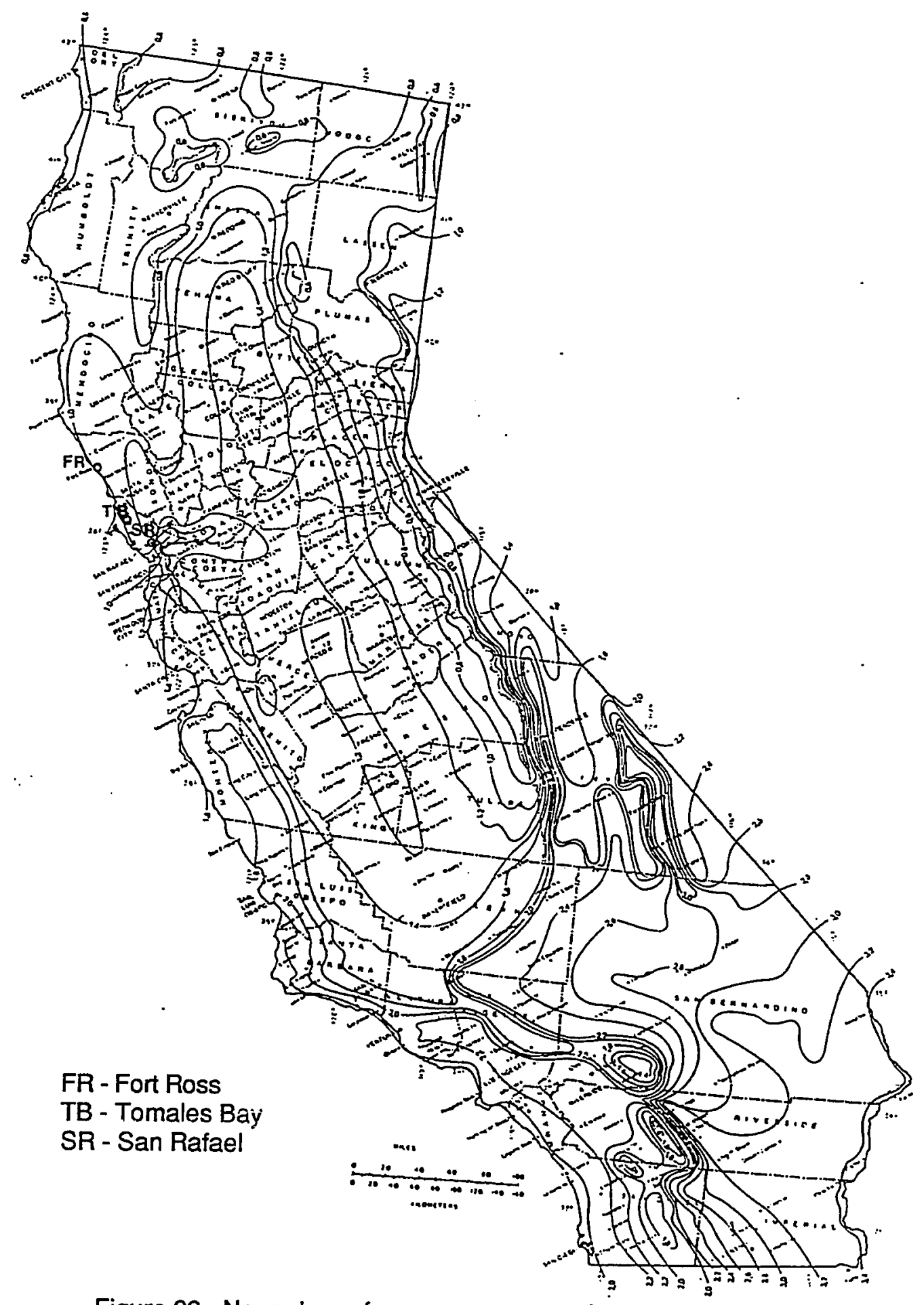

Figure 36. November reference evapotranspiration isoline map for California in $\mathrm{mm}$ per day (Snyder et al., 1987). 


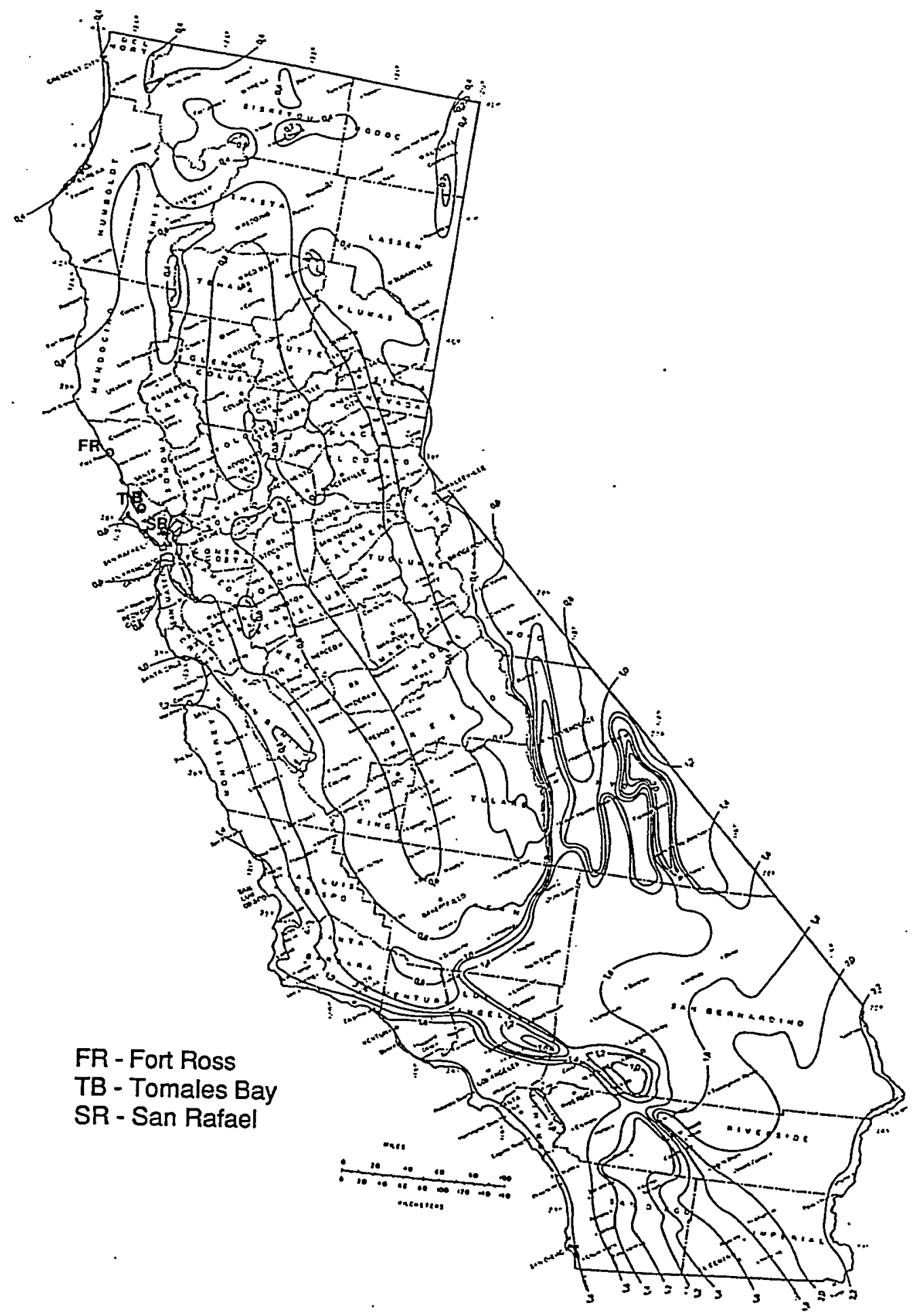

Figure 37. December reference evapotranspiration isoline map for California in mm per day (Snyder et al., 1987). 


\section{APPENDIX C}

Values for Phosphate, Nitrate-Nitrite, Ammonium, Silica, DIC, $\mathrm{pH}$, Alkalinity, Temperature, and Conductivity

in Sampled Wells in the Tomales Bay Watershed 


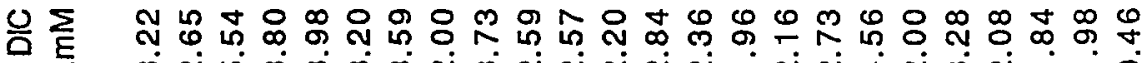

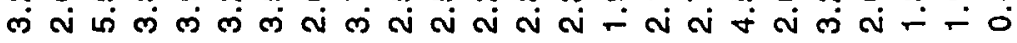

क ம்

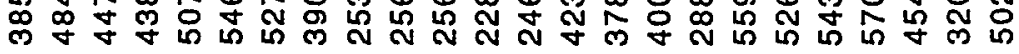

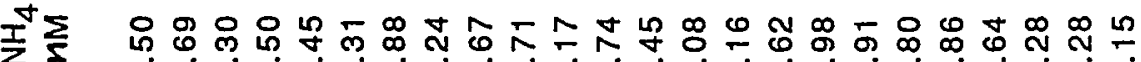

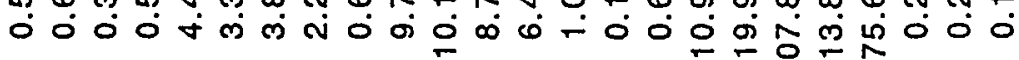

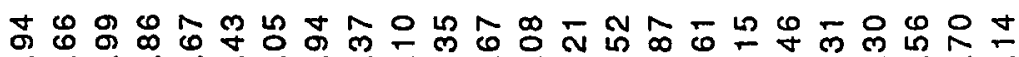

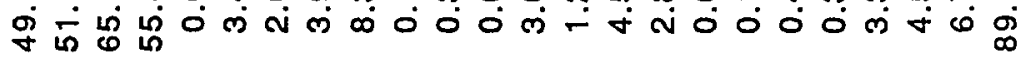

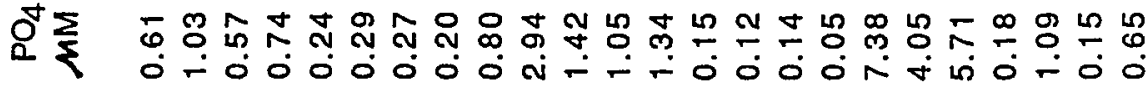

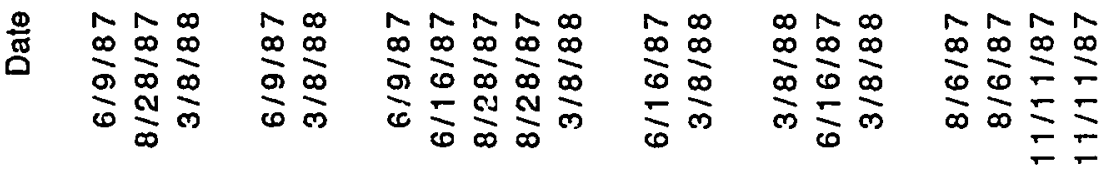

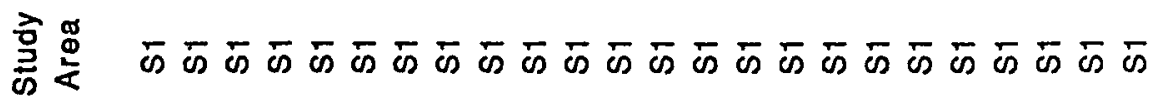

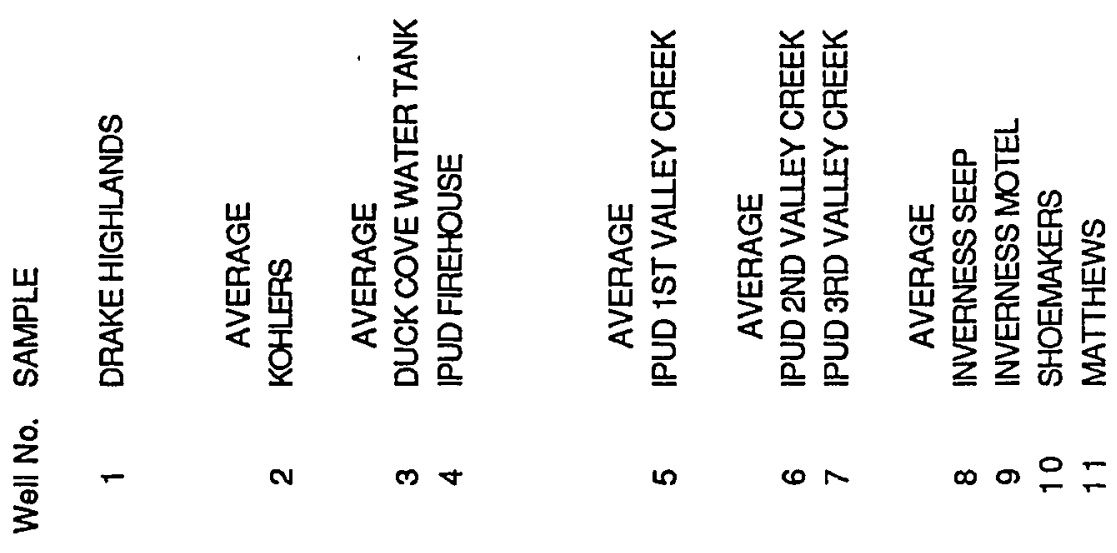




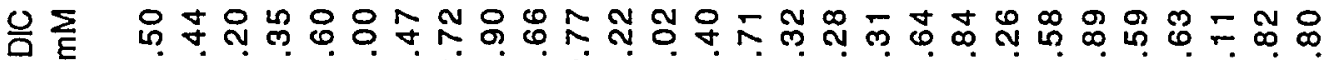

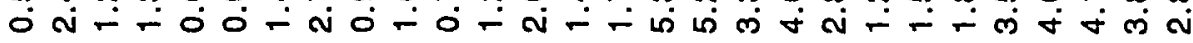

๘

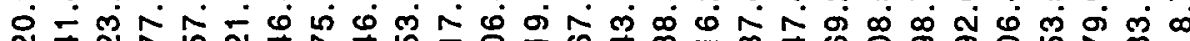

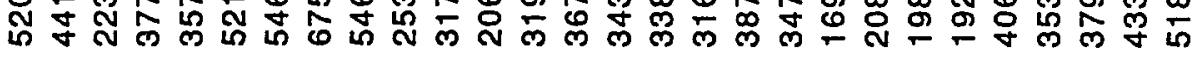

폴

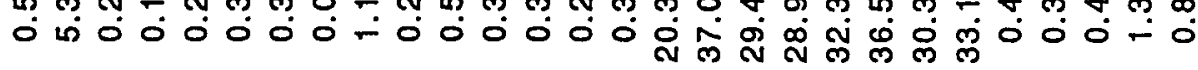

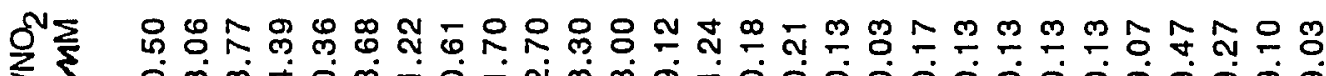

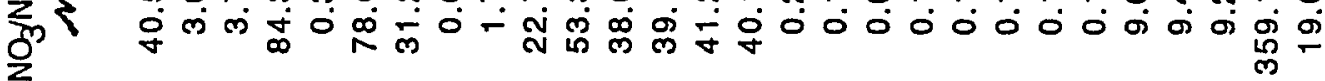

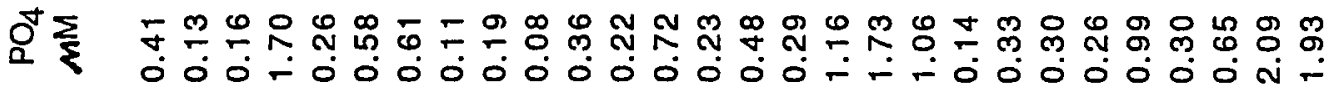

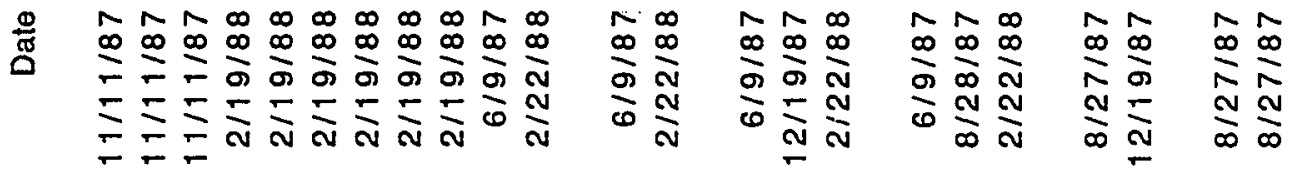

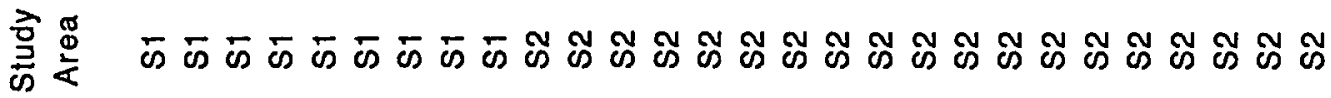

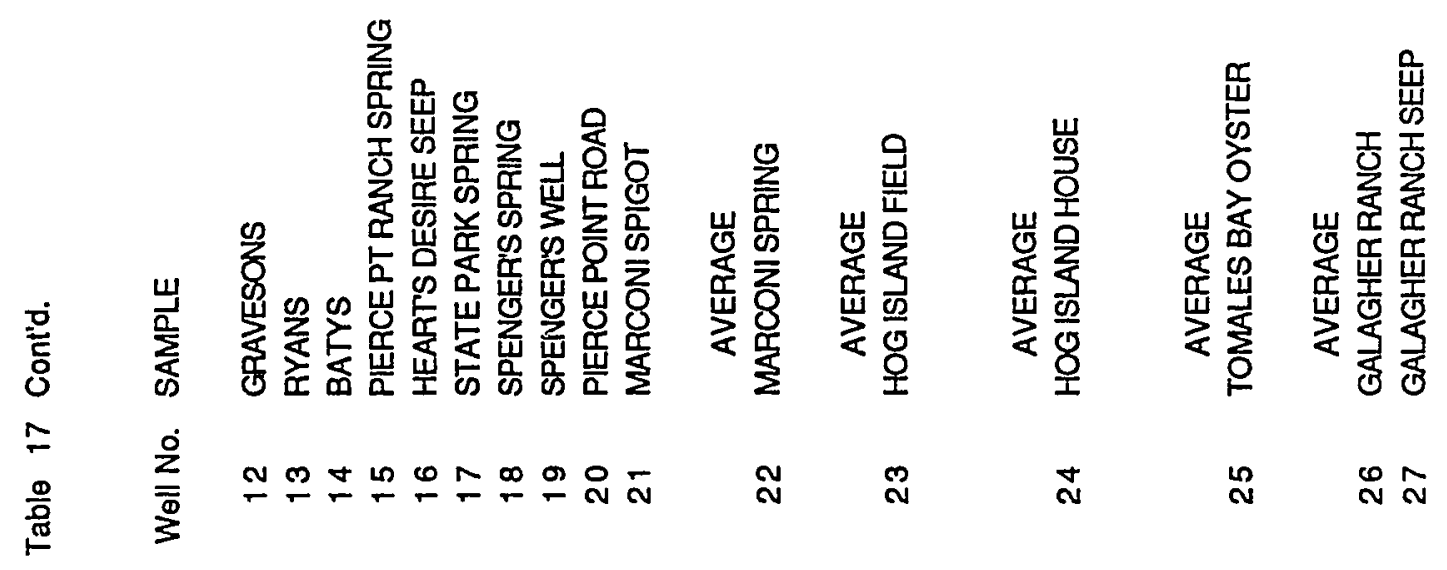




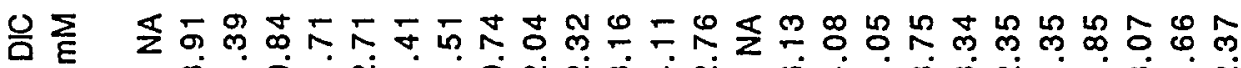

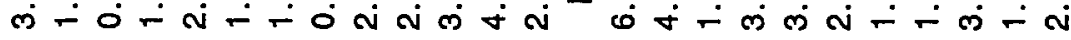

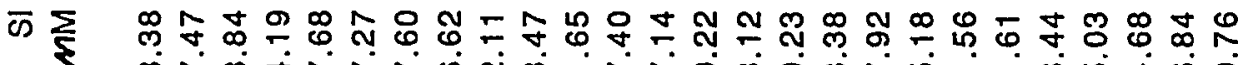
ळ

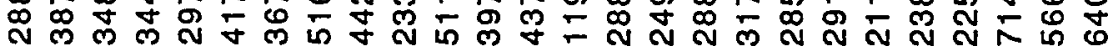

爱方 $\quad \bar{N}$

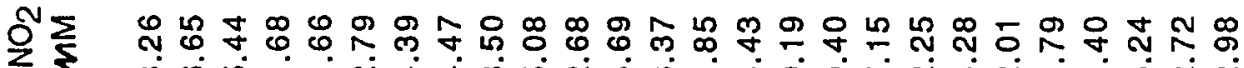

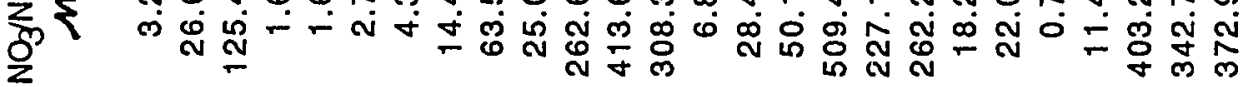

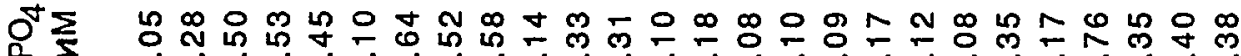

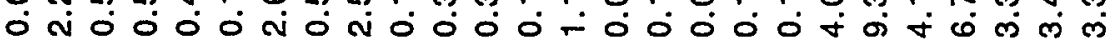

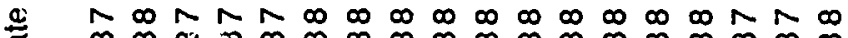

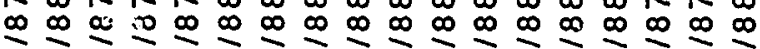

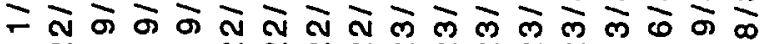

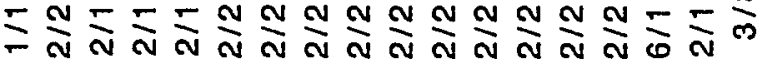

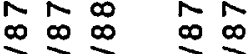
Nた心
$=\underset{\omega}{\frac{N}{\omega}}=\frac{N}{\infty}$

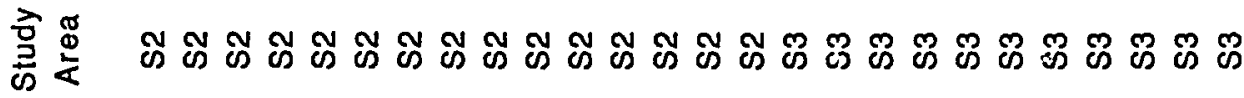

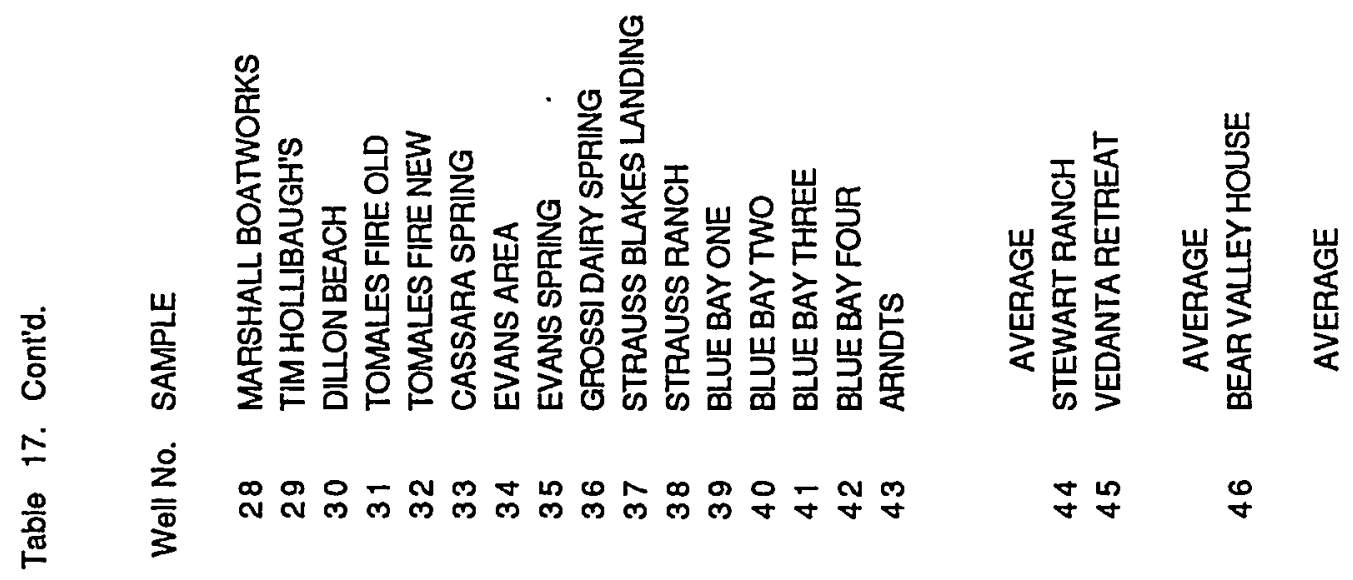




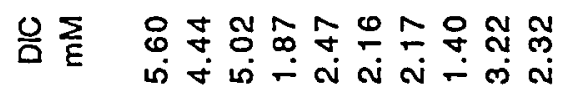

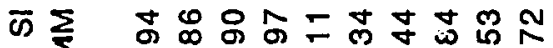

.

สู่

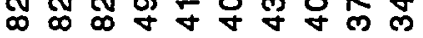

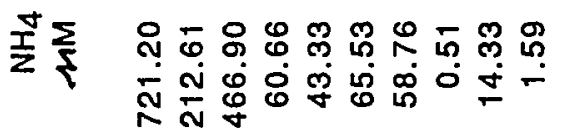

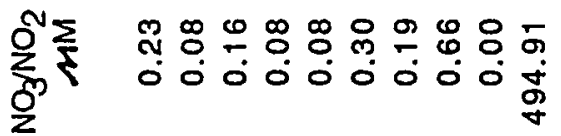

Ot

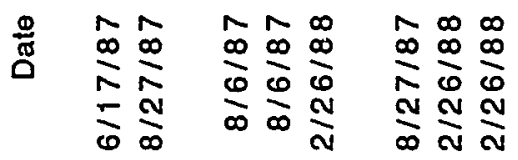

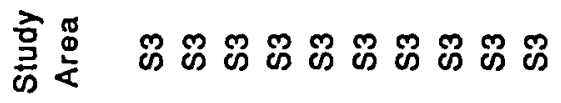

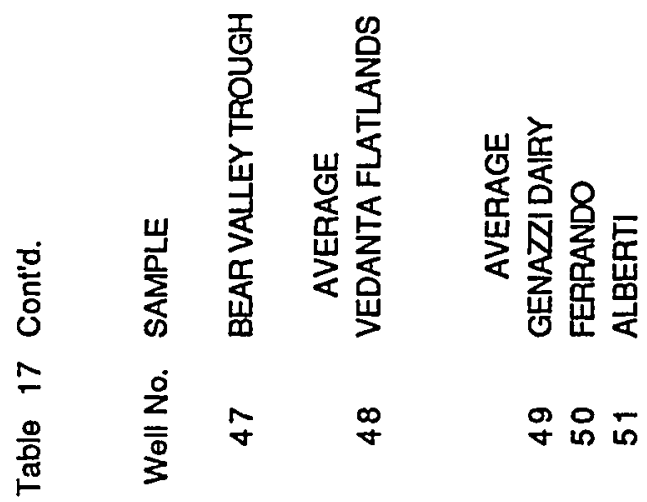




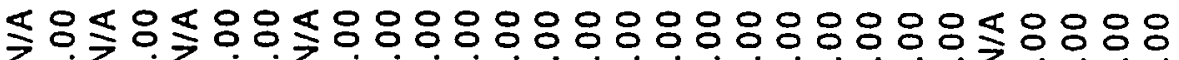

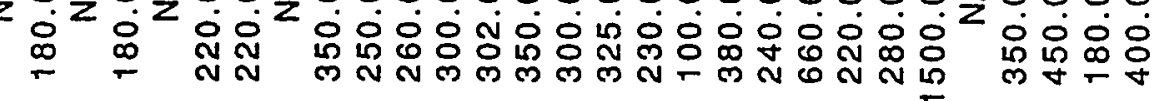

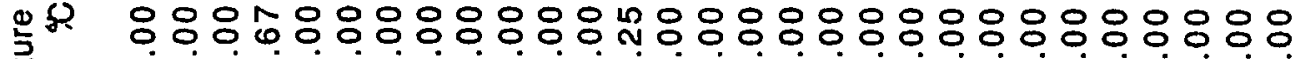

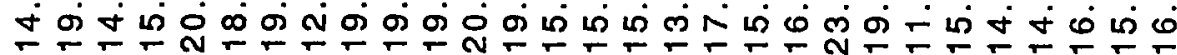

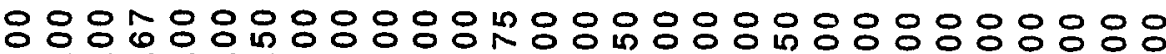
कि

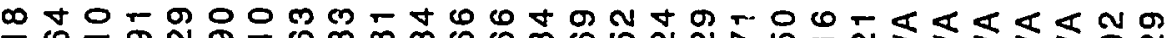

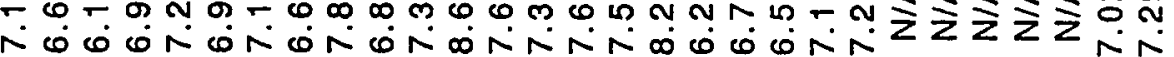

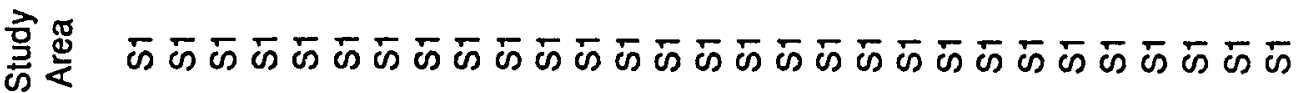

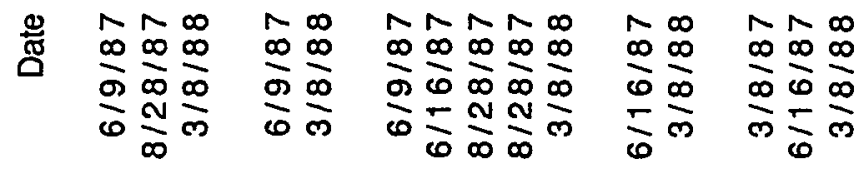
$\tau_{\infty} \wedge \sim \sim_{\infty}^{\infty} \sim \sim_{\infty}^{\infty} \infty$

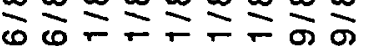
$\infty 亠 \mp=\Sigma \mp \mp 5$

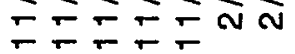
竞

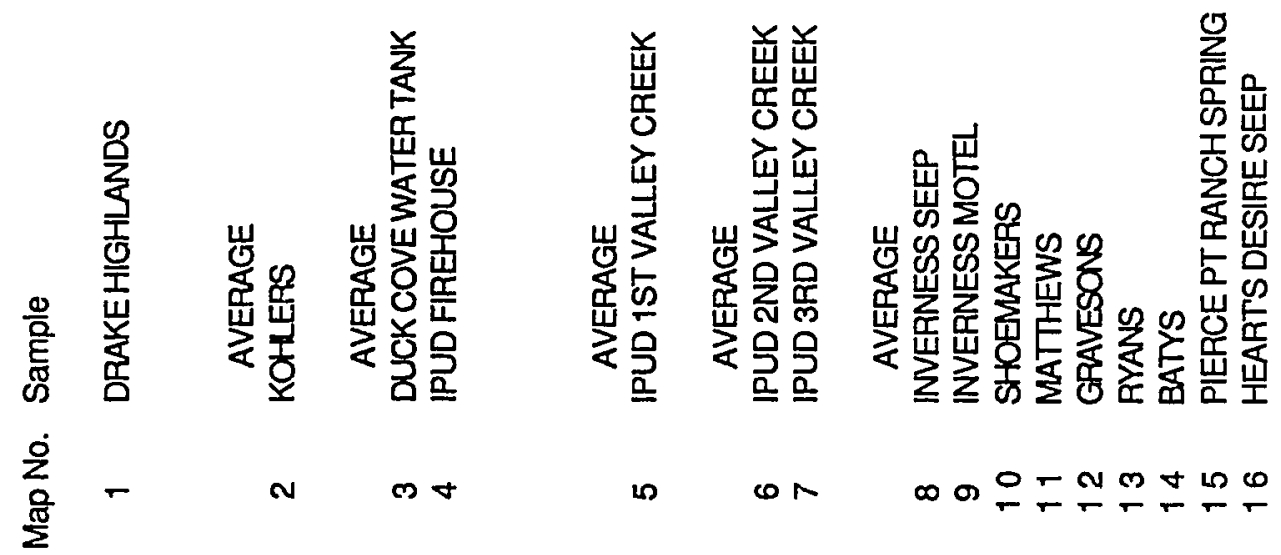




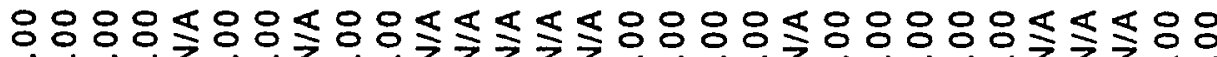

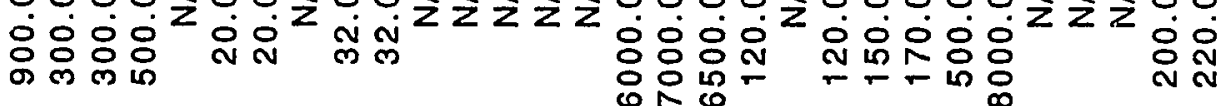

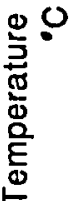

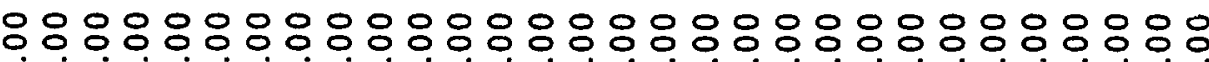

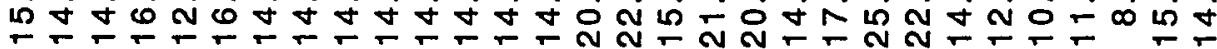

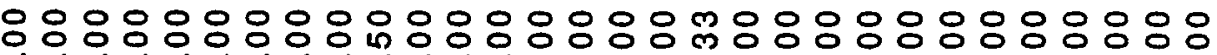
$\dot{0} \dot{0} \dot{0} \dot{0} \dot{0} \dot{0} \dot{0} \dot{0} \dot{0} \dot{0} \dot{0} \dot{0} \dot{0} \dot{0} \dot{0} \dot{0} \dot{0} \dot{0} \dot{0}$ m

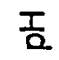

Nㅜㄴ i

率践

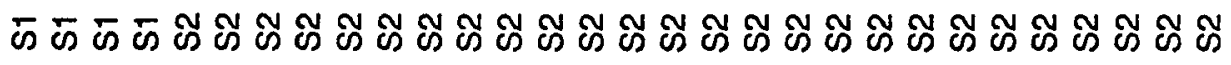

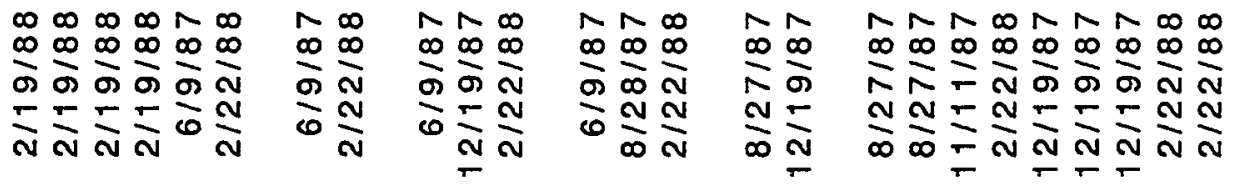
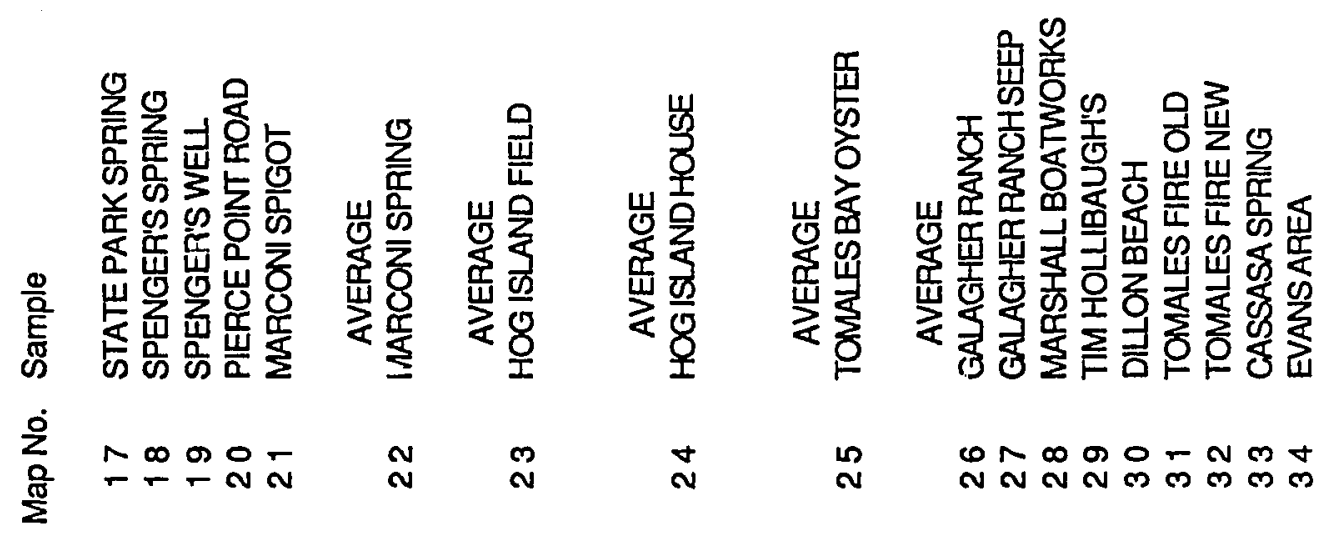

$\stackrel{N}{N} \quad \stackrel{N}{N}$

$\stackrel{+}{N}$

N

CNmarNm NN NMM M M 

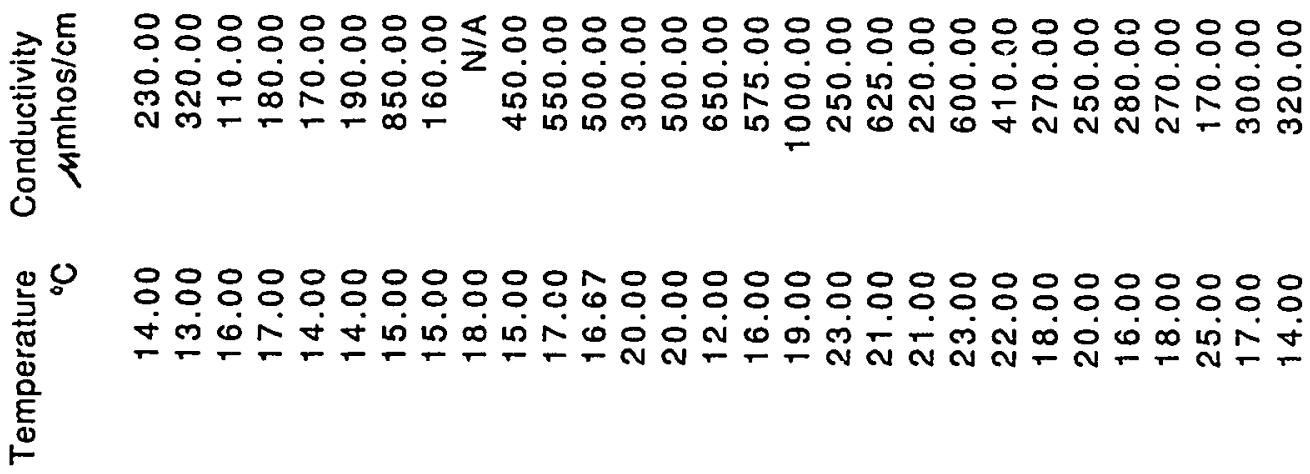

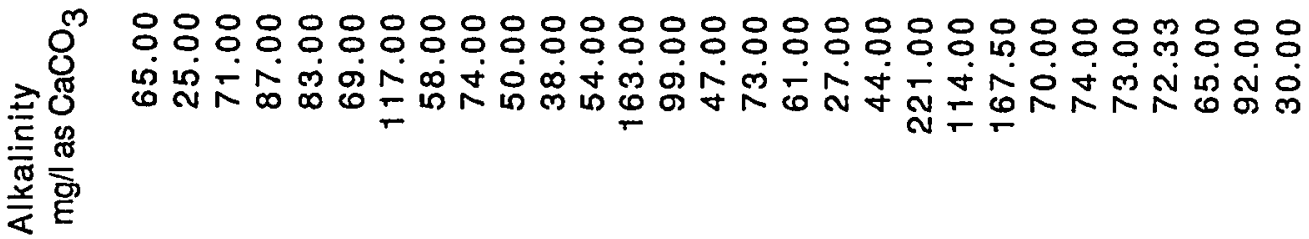

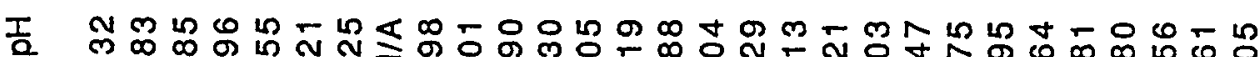
م

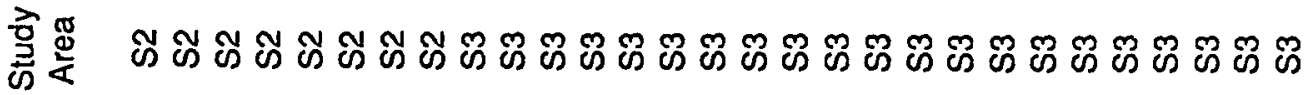

\begin{tabular}{|c|c|c|c|c|}
\hline 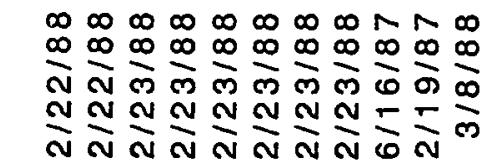 & 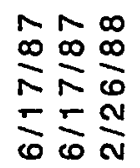 & $\begin{array}{l}N \\
\infty \\
\frac{\infty}{n} \\
\frac{N}{N} \\
\frac{N}{\infty}\end{array}$ & 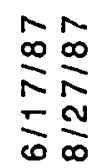 & 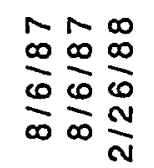 \\
\hline
\end{tabular}

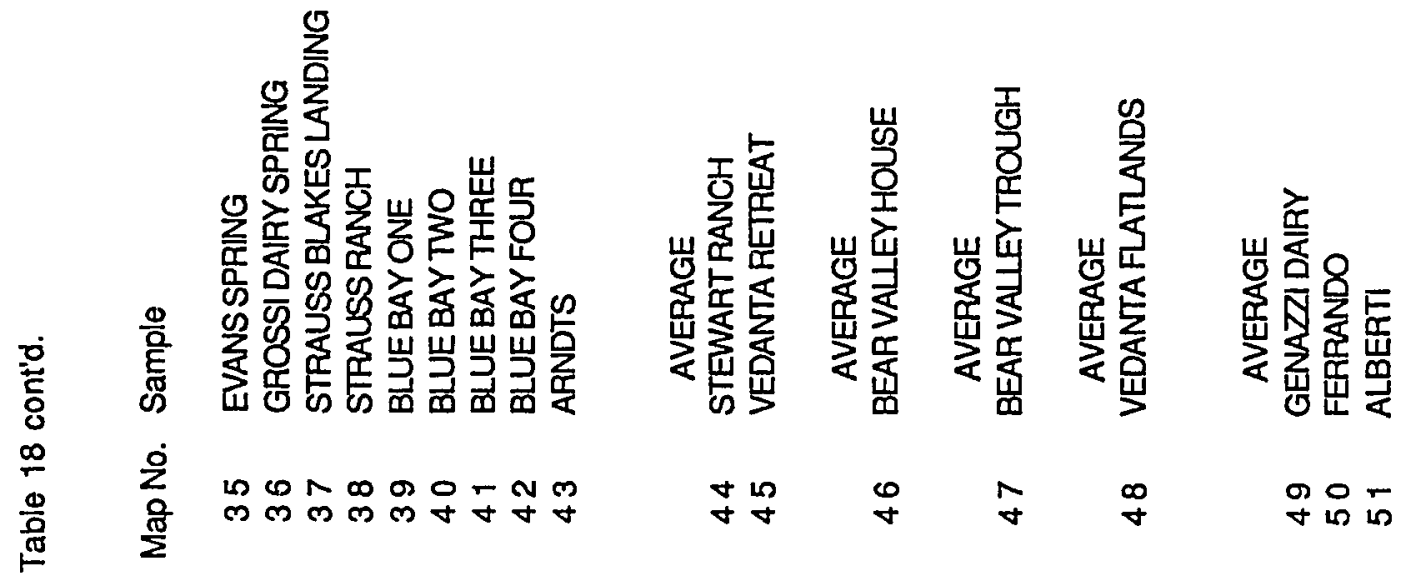




\section{APPENDIX D}

Groundwater Recharge Rate and Soil Moisture

Budget Tables for the Tomales Bay Watershed 
Table 19a. Estimate of lower limit groundwater recharge from precipitation for Kehoe-Inverness-Sheridan Variant soil in Study Area I (SM $=122 \mathrm{~mm}$ ).

\begin{tabular}{|c|c|c|c|c|c|c|c|}
\hline Month & $\begin{array}{l}\text { Precip. } \\
\text { (mm) }\end{array}$ & $\begin{array}{l}\text { Runoff } \\
(\mathrm{mm})\end{array}$ & $\begin{array}{r}\text { Effective } \\
\text { Precip. } \\
(\mathrm{mm})\end{array}$ & $\begin{array}{r}\text { Potential } \\
\text { ET. } \\
(\mathrm{mm})\end{array}$ & $\begin{array}{r}\text { Accum. Soil } \\
\text { Moisture } \\
(\mathrm{mm})\end{array}$ & $\begin{array}{r}\text { Actual } \\
E T . \\
(\mathrm{mm})\end{array}$ & $\begin{array}{r}\text { G.W. } \\
\text { Recharge } \\
(\mathrm{m} \mathrm{m})\end{array}$ \\
\hline 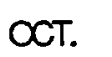 & 59 & 2 & 57 & 66 & 0 & 0 & 0 \\
\hline NOV. & 149 & 20 & 129 & 30 & 99 & 30 & 0 \\
\hline DEC. & 156 & 59 & 97 & 17 & 122 & 17 & 57 \\
\hline JAN. & 178 & 112 & 66 & 31 & 122 & 31 & 35 \\
\hline FEB. & 152 & 117 & 35 & 36 & 121 & 36 & 0 \\
\hline MAR. & 125 & 88 & 37 & 61 & 97 & 61 & 0 \\
\hline APR. & 48 & 25 & 23 & 76 & 43 & 43 & 0 \\
\hline MAY & 13 & 5 & 8 & 97 & 0 & 0 & 0 \\
\hline JUN. & 8 & 2 & 6 & 122 & 0 & 0 & 0 \\
\hline JUL. & 9 & 2 & 7 & 112 & 0 & 0 & 0 \\
\hline AUG. & 10 & 2 & 8 & 114 & 0 & 0 & 0 \\
\hline SEP. & 19 & 2 & 17 & 98 & 0 & 0 & 0 \\
\hline Total & 926 & 436 & 490 & 860 & & 218 & 92 \\
\hline
\end{tabular}

Table 19b. Estimate of upper limit groundwater recharge from precipitation for Kehoe-Inverness-Sheridan Variant soil in Study Area I $(S M=61 \mathrm{~mm})$.

\begin{tabular}{|c|c|c|c|c|c|c|c|}
\hline Month & $\begin{array}{l}\text { Precip. } \\
(\mathrm{mm})\end{array}$ & $\begin{array}{l}\text { Runoff } \\
(\mathrm{mm})\end{array}$ & $\begin{array}{l}\text { Effective } \\
\text { Precip. } \\
(\mathrm{mm})\end{array}$ & $\begin{array}{r}\text { Potential } \\
\text { ET. } \\
(\mathrm{mm})\end{array}$ & $\begin{array}{r}\text { Accum. Soil } \\
\text { Moisture } \\
(\mathrm{m} \mathrm{m})\end{array}$ & $\begin{array}{r}\text { Actual } \\
\text { ET. } \\
(\mathrm{m} \mathrm{m})\end{array}$ & $\begin{array}{r}\text { G.W. } \\
\text { Recharge } \\
(\mathrm{mm})\end{array}$ \\
\hline ○). & 59 & 2 & 57 & 66 & 0 & 0 & 0 \\
\hline NOV. & 149 & 20 & 129 & 30 & 61 & 30 & 38 \\
\hline DEC. & 156 & 59 & 97 & 17 & 61 & 17 & 80 \\
\hline JAN. & 178 & 112 & 66 & 31 & 61 & 31 & 35 \\
\hline FEB. & 152 & 117 & 35 & 36 & 60 & 36 & 0 \\
\hline MAR. & 125 & 88 & 37 & 61 & 42 & 61 & 0 \\
\hline APR. & 48 & 25 & 23 & 76 & 18 & 0 & 0 \\
\hline MAY & 13 & 5 & 8 & 97 & 0 & 0 & 0 \\
\hline JUN. & 8 & 2 & 6 & 122 & 0 & 0 & 0 \\
\hline JUL. & 9 & 2 & 7 & 112 & 0 & 0 & 0 \\
\hline AUG. & 10 & 2 & 8 & 114 & 0 & 0 & 0 \\
\hline SEP. & 19 & 2 & 17 & 98 & 0 & 0 & 0 \\
\hline otal & 926 & 436 & 490 & 860 & & 175 & 153 \\
\hline
\end{tabular}


Table 20. Estimate of groundwater recharge from precipitation for Bulcher-Cole soil in Study Area II (SM = $213 \mathrm{~mm}$ ).

\begin{tabular}{|c|c|c|c|c|c|c|c|}
\hline Month & $\begin{array}{r}\text { Precip. } \\
(\mathrm{m} \mathrm{m})\end{array}$ & $\begin{array}{l}\text { Runoff } \\
(\mathrm{mm})\end{array}$ & $\begin{array}{r}\text { Effective } \\
\text { Precip. } \\
(\mathrm{mm})\end{array}$ & $\begin{array}{r}\text { Potential } \\
E T . \\
(\mathrm{mm})\end{array}$ & $\begin{array}{r}\text { Accum. Soil } \\
\text { Moisture } \\
(\mathrm{mm})\end{array}$ & $\begin{array}{r}\text { Actual } \\
\text { ET. } \\
(\mathrm{mm})\end{array}$ & $\begin{array}{r}\text { G.W. } \\
\text { Recharge } \\
(\mathrm{m} \mathrm{m})\end{array}$ \\
\hline ○T. & 48 & 2 & 46 & 66 & 0 & 0 & 0 \\
\hline NOV. & 122 & 20 & 102 & 30 & 72 & 30 & 0 \\
\hline DEC. & 127 & 59 & 68 & 17 & 123 & 17 & 0 \\
\hline JAN. & 147 & 112 & 35 & 31 & 127 & 31 & 0 \\
\hline FEB. & 125 & 117 & 8 & 36 & 99 & 36 & 0 \\
\hline MAR. & 102 & 88 & 14 & 61 & 52 & 52 & 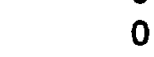 \\
\hline APR. & 39 & 25 & 14 & 76 & 0 & 0 & \\
\hline MAY & 10 & 5 & 5 & 97 & 0 & 0 & 0 \\
\hline JUN. & 6 & 2 & 4 & 122 & 0 & 0 & \\
\hline JUL. & 7 & 2 & 5 & 112 & 0 & 0 & 0 \\
\hline AUG & 8 & 2 & 6 & 114 & 0 & 0 & 0 \\
\hline SEPT. & 15 & 2 & 13 & 98 & 0 & 0 & 0 \\
\hline Total & 756 & 436 & 320 & 860 & & 166 & 4 \\
\hline
\end{tabular}


Table 21. Estimate of groundwater recharge from precipitation for Duneland soil in Study Area II (SM = $128 \mathrm{~mm}$ ).

\begin{tabular}{|c|c|c|c|c|c|c|c|}
\hline Month & $\begin{array}{r}\text { Precip. } \\
\text { (m m) }\end{array}$ & $\begin{array}{l}\text { Runoff } \\
(\mathrm{mm})\end{array}$ & $\begin{array}{r}\text { Effective } \\
\text { Precip. } \\
(\mathrm{mm})\end{array}$ & $\begin{array}{r}\text { Potential } \\
E T . \\
(\mathrm{mm})\end{array}$ & $\begin{array}{r}\text { Accum. Soil } \\
\text { Moisture } \\
(\mathrm{mm})\end{array}$ & $\begin{array}{r}\text { Actual } \\
\text { ET. } \\
(\mathrm{mm})\end{array}$ & $\begin{array}{r}\text { G.W. } \\
\text { Recharge } \\
(\mathrm{mm})\end{array}$ \\
\hline$\infty$. & 48 & 2 & 46 & 66 & 0 & 0 & 0 \\
\hline NOV. & 122 & 20 & 102 & 30 & 72 & 30 & 0 \\
\hline DEC. & 127 & 59 & 68 & 17 & 123 & 17 & 0 \\
\hline JAN. & 147 & 112 & 35 & 31 & 127 & 31 & 0 \\
\hline FEB. & 125 & 117 & 8 & 36 & 99 & 36 & 0 \\
\hline MAR. & 102 & 88 & 14 & 61 & 52 & 52 & 0 \\
\hline APR. & 39 & 25 & 14 & 76 & 0 & 0 & 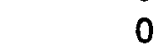 \\
\hline MAY & 10 & 5 & 5 & 97 & 0 & 0 & 0 \\
\hline JUN. & 6 & 2 & 4 & 122 & 0 & 0 & 0 \\
\hline JUL. & 7 & 2 & 5 & 112 & 0 & 0 & 0 \\
\hline AUG & 8 & 2 & 6 & 114 & 0 & 0 & 0 \\
\hline SEPT. & 15 & 2 & 13 & 98 & 0 & 0 & 0 \\
\hline otal & 756 & 436 & 320 & 860 & & 166 & \\
\hline
\end{tabular}


Table 22a. Estimate of lower limit groundwater recharge from precipitation for Olompali-Felton-Soulajoule soil in Study Area II (SM = $213 \mathrm{~mm})$.

\begin{tabular}{|c|c|c|c|c|c|c|c|}
\hline Month & $\begin{array}{l}\text { Precip. } \\
(\mathrm{mm})\end{array}$ & $\begin{array}{l}\text { Runoff } \\
(\mathrm{mm})\end{array}$ & $\begin{array}{r}\text { Effective } \\
\text { Precip. } \\
(\mathrm{mm})\end{array}$ & $\begin{array}{r}\text { Potential } \\
E T . \\
(\mathrm{mm})\end{array}$ & $\begin{array}{r}\text { Accum. Soil } \\
\text { Moisture } \\
(\mathrm{mm})\end{array}$ & $\begin{array}{r}\text { Actual } \\
E T . \\
(\mathrm{mm})\end{array}$ & $\begin{array}{r}\text { G.W. } \\
\text { Recharge } \\
(\mathrm{m} \mathrm{m})\end{array}$ \\
\hline ळт. & 48 & 2 & 46 & 66 & 0 & 0 & 0 \\
\hline NOV. & 122 & 20 & 102 & 30 & 72 & 30 & 0 \\
\hline DEC. & 127 & 59 & 68 & 17 & 123 & 17 & 0 \\
\hline JAN. & 147 & 112 & 35 & 31 & 127 & 31 & 0 \\
\hline FEB. & 125 & 117 & 8 & 36 & 99 & 36 & 0 \\
\hline MAR. & 102 & 88 & 14 & 61 & 52 & 52 & 0 \\
\hline APR. & 39 & 25 & 14 & 76 & 0 & 0 & 0 \\
\hline MAY & 10 & 5 & 5 & 97 & 0 & 0 & 0 \\
\hline JUN. & 6 & 2 & 4 & 122 & 0 & 0 & 0 \\
\hline JUL. & 7 & 2 & 5 & 112 & 0 & 0 & 0 \\
\hline AUG. & 8 & 2 & 6 & 114 & 0 & 0 & 0 \\
\hline SEPT. & 15 & 2 & 13 & 98 & 0 & 0 & 0 \\
\hline Total & 756 & 436 & 320 & 860 & & 166 & 0 \\
\hline
\end{tabular}

Table 22b. Estimate of upper limit groundwater recharge from precipitation for Olompali-Felton-Soulajoule soil in Study Area II $(S M=142 \mathrm{~mm})$.

\begin{tabular}{|c|c|c|c|c|c|c|c|}
\hline Month & $\begin{array}{l}\text { Precip. } \\
\text { (m m) }\end{array}$ & $\begin{array}{l}\text { Runoff } \\
(\mathrm{mm})\end{array}$ & $\begin{array}{r}\text { Effective } \\
\text { Precip. } \\
(\mathrm{mm})\end{array}$ & $\begin{array}{r}\text { Potential } \\
\text { ET. } \\
(\mathrm{mm})\end{array}$ & $\begin{array}{r}\text { Accum. Soil } \\
\text { Moisture } \\
(\mathrm{m} \mathrm{m})\end{array}$ & $\begin{array}{l}\text { Actual } \\
\text { ET. } \\
(\mathrm{mm})\end{array}$ & $\begin{array}{r}\text { G.W. } \\
\text { Recharge } \\
(\mathrm{m} \mathrm{m})\end{array}$ \\
\hline C.T. & 48 & 2 & 46 & 66 & 0 & 0 & \\
\hline NOV. & 122 & 20 & 102 & 30 & 72 & 30 & \\
\hline DEC. & 127 & 59 & 68 & 17 & 123 & 17 & \\
\hline JAN. & 147 & 112 & 35 & 31 & 127 & 31 & \\
\hline FEB. & 125 & 117 & 8 & 36 & 99 & 36 & \\
\hline MAR. & 102 & 88 & 14 & 61 & 52 & 52 & \\
\hline APR. & 39 & 25 & 14 & 76 & 0 & 0 & \\
\hline MAY & 10 & 5 & 5 & 97 & 0 & 0 & \\
\hline JUN. & 6 & 2 & 4 & 122 & 0 & 0 & \\
\hline JUL. & 7 & 2 & 5 & 112 & 0 & 0 & \\
\hline AUG. & 8 & 2 & 6 & 114 & 0 & 0 & \\
\hline SEPT. & 15 & 2 & 13 & 98 & 0 & 0 & \\
\hline Total & 756 & 436 & 320 & 860 & & 166 & \\
\hline
\end{tabular}


Table 23a. Estimate of lower limit groundwater recharge from precipitation for Tocaloma-Saurin soil in Study Area II (SM = $152 \mathrm{~mm}$ ).

\begin{tabular}{|c|c|c|c|c|c|c|c|}
\hline Month & $\begin{array}{l}\text { Precip. } \\
(\mathrm{mm})\end{array}$ & $\begin{array}{l}\text { Runoff } \\
(\mathrm{m} \mathrm{m})\end{array}$ & $\begin{array}{c}\text { E:fective } \\
\text { Precip. } \\
(\mathrm{mm})\end{array}$ & $\begin{array}{r}\text { Potential } \\
\text { ET. } \\
(\mathrm{mm})\end{array}$ & $\begin{array}{r}\text { Accuin. Soil } \\
\text { Mristure } \\
(\mathrm{m} \mathrm{m})\end{array}$ & $\begin{array}{r}\text { Actual } \\
\text { ET. } \\
(\mathrm{mm})\end{array}$ & $\begin{array}{r}\text { G.W. } \\
\text { Recharge } \\
(\mathrm{m} \mathrm{m})\end{array}$ \\
\hline$\infty$. & 48 & 2 & 46 & 66 & 0 & 0 & 0 \\
\hline NOV. & 122 & 20 & 102 & 30 & 72 & 30 & 0 \\
\hline DEC. & 127 & 59 & 68 & 17 & 123 & 17 & 0 \\
\hline JAN. & 147 & 112 & 35 & 31 & 127 & 31 & 0 \\
\hline FEB. & 125 & 117 & 8 & 36 & 99 & 36 & 0 \\
\hline MAR. & 102 & 88 & 14 & 61 & 52 & 52 & 0 \\
\hline APR. & 39 & 25 & 14 & 76 & 0 & 0 & 0 \\
\hline MAY & 10 & 5 & 5 & 97 & 0 & 0 & 0 \\
\hline JUN. & 6 & 2 & 4 & 122 & 0 & 0 & 0 \\
\hline JUL. & 7 & 2 & 5 & 112 & 0 & 0 & 0 \\
\hline AUG & 8 & 2 & 6 & 114 & 0 & 0 & 0 \\
\hline SEPT. & 15 & 2 & 13 & 98 & 0 & 0 & 0 \\
\hline Total & 756 & 436 & 320 & 860 & & 166 & 0 \\
\hline
\end{tabular}

Table 23b. Estimate of upper limit groundwater recharge from precipitation for Tocaloma-Saurin soil in Study Area II (SM = $76 \mathrm{~mm})$.

\begin{tabular}{|c|c|c|c|c|c|c|c|}
\hline Month & $\begin{array}{l}\text { Precip. } \\
(\mathrm{mm})\end{array}$ & $\begin{array}{r}\text { Runoff } \\
(\mathrm{mm})\end{array}$ & $\begin{array}{r}\text { Effective } \\
\text { Precip. } \\
(\mathrm{mm})\end{array}$ & $\begin{array}{r}\text { Potential } \\
E T . \\
(\mathrm{mm})\end{array}$ & $\begin{array}{r}\text { Accum. Soil } \\
\text { Moisture } \\
(\mathrm{mm})\end{array}$ & $\begin{array}{r}\text { Actual } \\
\text { ET. } \\
(\mathrm{m} \mathrm{m})\end{array}$ & $\begin{array}{r}\text { G.W. } \\
\text { Recharge } \\
(\mathrm{m} \mathrm{m})\end{array}$ \\
\hline ○). & 48 & 2 & 46 & 66 & 0 & 0 & 0 \\
\hline NOV. & 122 & 20 & 102 & 30 & 72 & 30 & 0 \\
\hline DEC. & 127 & 59 & 68 & 17 & 76 & 17 & 47 \\
\hline JAN. & 147 & 112 & 35 & 31 & 76 & 31 & 4 \\
\hline FEB. & 125 & 117 & 8 & 36 & 48 & 36 & 0 \\
\hline MAR. & 102 & 88 & 14 & 61 & 2 & 2 & 0 \\
\hline APR. & 39 & 25 & 14 & 76 & 0 & 0 & 0 \\
\hline MAY & 10 & 5 & 5 & 97 & 0 & 0 & 0 \\
\hline JUN. & 6 & 2 & 4 & 122 & 0 & 0 & 0 \\
\hline JUL. & 7 & 2 & 5 & 112 & 0 & 0 & 0 \\
\hline AUG. & 8 & 2 & 6 & 114 & 0 & 0 & 0 \\
\hline SEPT. & 15 & 2 & 13 & 98 & 0 & 0 & 0 \\
\hline Total & 756 & 436 & 320 & 860 & & 116 & 51 \\
\hline
\end{tabular}


Table 24a. Estimate of lower limit groundwater recharge from precipitation for Los Osos-Bonnydoon soil in Study Area $\|$ (SM = $124 \mathrm{~mm})$.

\begin{tabular}{|c|c|c|c|c|c|c|c|}
\hline Month & $\begin{array}{r}\text { Precip. } \\
(\mathrm{mm})\end{array}$ & $\begin{array}{l}\text { Runoff } \\
(\mathrm{mm})\end{array}$ & $\begin{array}{r}\text { Effective } \\
\text { Precip. } \\
(\mathrm{mm})\end{array}$ & $\begin{array}{r}\text { Potential } \\
\text { ET. } \\
(\mathrm{mm})\end{array}$ & $\begin{array}{r}\text { Accum. Soil } \\
\text { Moisture } \\
(\mathrm{mm})\end{array}$ & $\begin{array}{r}\text { Actual } \\
\text { ET. } \\
(\mathrm{m} \mathrm{m})\end{array}$ & $\begin{array}{r}\text { G.W. } \\
\text { Recharge } \\
(\mathrm{m} \mathrm{m})\end{array}$ \\
\hline$\infty$ CT. & 48 & 2 & 46 & 66 & 0 & 0 & 0 \\
\hline NOV. & 122 & 20 & 102 & 30 & 72 & 30 & U \\
\hline DEC. & 127 & 59 & 68 & 17 & 123 & 17 & 0 \\
\hline JAN. & 147 & 112 & 35 & 31 & 124 & 31 & 4 \\
\hline FEB. & 125 & 117 & 8 & 36 & 97 & 36 & 0 \\
\hline MAR. & 102 & 88 & 14 & 61 & 50 & 50 & 0 \\
\hline APR. & 39 & 25 & 14 & 76 & 0 & 0 & 0 \\
\hline MAY & 10 & 5 & 5 & 97 & 0 & 0 & 0 \\
\hline JUN. & 6 & 2 & 4 & 122 & 0 & 0 & \\
\hline JUL. & 7 & 2 & 5 & 112 & 0 & 0 & \\
\hline AUG. & 8 & 2 & 6 & 114 & 0 & 0 & \\
\hline SEPT. & 15 & 2 & 13 & 98 & 0 & 0 & \\
\hline otal & 756 & 436 & 320 & 860 & & 164 & \\
\hline
\end{tabular}

Table 24b. Estimate of upper limit groundwater recharge from precipitation for Los Osos-Bonnydoon soil in Study Area II (SM =64 mm).

\begin{tabular}{|c|c|c|c|c|c|c|c|}
\hline Month & $\begin{array}{l}\text { Precip. } \\
(\mathrm{mm})\end{array}$ & $\begin{array}{l}\text { Runoff } \\
(\mathrm{m} \mathrm{m})\end{array}$ & $\begin{array}{r}\text { Effective } \\
\text { Precip. } \\
(\mathrm{m} \mathrm{m})\end{array}$ & $\begin{array}{r}\text { Potential } \\
\text { ET. } \\
(\mathrm{mm})\end{array}$ & $\begin{array}{r}\text { Accum. Soil } \\
\text { Moisture } \\
(\mathrm{mm})\end{array}$ & $\begin{array}{l}\text { Actual } \\
\text { ET. } \\
(\mathrm{m} \mathrm{m})\end{array}$ & $\begin{array}{r}\text { G.W. } \\
\text { Recharge } \\
(\mathrm{m} \mathrm{m})\end{array}$ \\
\hline œT. & 48 & 2 & 46 & 66 & 0 & 0 & 0 \\
\hline NDV. & 122 & 20 & 102 & 30 & 64 & 30 & 8 \\
\hline DEC. & 127 & 59 & 68 & 17 & 64 & 17 & 47 \\
\hline JAN. & 147 & 112 & 35 & 31 & 64 & 31 & 4 \\
\hline FEB. & 125 & 117 & 8 & 36 & 36 & 36 & 0 \\
\hline MAR. & 102 & 88 & 14 & 61 & 0 & 0 & 0 \\
\hline APR. & 39 & 25 & 14 & 76 & 0 & 0 & 0 \\
\hline MAY & 10 & 5 & 5 & 97 & 0 & 0 & 0 \\
\hline JUN. & 6 & 2 & 4 & 122 & 0 & 0 & 0 \\
\hline JUL. & 7 & 2 & 5 & 112 & 0 & 0 & 0 \\
\hline AUG & 8 & 2 & 6 & 114 & 0 & 0 & 0 \\
\hline SEPT. & 15 & 2 & 13 & 98 & 0 & 0 & 0 \\
\hline otal & 756 & 436 & 320 & 860 & & 114 & 59 \\
\hline
\end{tabular}


Table 25. Estimate of groundwater recharge from precipitation for Bulcher-Cole soil in Study Area III (SM = $244 \mathrm{~mm})$.

\begin{tabular}{|c|c|c|c|c|c|c|c|}
\hline Month & $\begin{array}{r}\text { Precip. } \\
(\mathrm{mm})\end{array}$ & $\begin{array}{l}\text { Runoff } \\
(\mathrm{m} m)\end{array}$ & $\begin{array}{r}\text { Effective } \\
\text { Precip. } \\
(\mathrm{mm})\end{array}$ & $\begin{array}{r}\text { Potential } \\
\text { ET. } \\
(\mathrm{mm})\end{array}$ & $\begin{array}{r}\text { Accum. Soil } \\
\text { Moisture } \\
(\mathrm{mm})\end{array}$ & $\begin{array}{l}\text { Actual } \\
\text { ET. } \\
(\mathrm{mm})\end{array}$ & $\begin{array}{r}\text { G.W. } \\
\text { Recharge } \\
(\mathrm{m} \mathrm{m})\end{array}$ \\
\hline ळт. & 72 & 2 & 70 & 66 & 4 & 4 & 0 \\
\hline NOV. & 185 & 20 & 165 & 30 & 139 & 30 & 0 \\
\hline DEC. & 197 & 59 & 138 & 17 & 244 & 17 & 16 \\
\hline JAN. & 216 & 112 & 104 & 31 & 244 & 31 & 73 \\
\hline FEB. & 184 & 117 & 67 & 36 & 244 & 36 & 31 \\
\hline MAR. & 153 & 88 & 65 & 61 & 244 & 61 & 4 \\
\hline APR. & 55 & 25 & 30 & 76 & 198 & 76 & 0 \\
\hline MAY & 11 & 5 & 6 & 97 & 107 & 97 & 0 \\
\hline JUN. & 4 & 2 & 2 & 122 & 0 & 0 & 0 \\
\hline JUL. & 6 & 2 & 4 & 112 & 0 & 0 & 0 \\
\hline AUG. & 8 & 2 & 6 & 114 & 0 & 0 & 0 \\
\hline SEPT. & 21 & 2 & 19 & 98 & 0 & 0 & 0 \\
\hline Total & 1112 & 436 & 676 & 860 & & 352 & 124 \\
\hline
\end{tabular}


Table 26a. Estimate of lower Imit groundwater recharge from precipitation for Kehoe-Inverness-Sheridan-Variant soil in Study Area III (SM $=122 \mathrm{~mm}$ ).

\begin{tabular}{|c|c|c|c|c|c|c|c|}
\hline Month & $\begin{array}{l}\text { Precip. } \\
(\mathrm{mm})\end{array}$ & $\begin{array}{l}\text { Runoff } \\
(\mathrm{mm})\end{array}$ & $\begin{array}{r}\text { Effective } \\
\text { Precip. } \\
(\mathrm{m} \mathrm{m})\end{array}$ & $\begin{array}{r}\text { Potential } \\
\text { ET. } \\
(\mathrm{m} \mathrm{m})\end{array}$ & $\begin{array}{r}\text { Accum. Soil } \\
\text { Moisture } \\
(\mathrm{m} \mathrm{m})\end{array}$ & $\begin{array}{r}\text { Actual } \\
\text { ET. } \\
(\mathrm{m} \mathrm{m})\end{array}$ & $\begin{array}{r}\text { G.W. } \\
\text { Recharge } \\
(\mathrm{m} \mathrm{m})\end{array}$ \\
\hline$\infty \mathrm{\infty T.}$ & 72 & 2 & 70 & 66 & 4 & 4 & 0 \\
\hline NOV. & $18 \overline{5}$ & 20 & 165 & 30 & 122 & 30 & 13 \\
\hline DEC. & 197 & 59 & 138 & 17 & 122 & 17 & 121 \\
\hline JAN. & 216 & 112 & 104 & 31 & 122 & 31 & 73 \\
\hline FEB. & 184 & 117 & 67 & 36 & 122 & 36 & 31 \\
\hline MAR. & 153 & 88 & 65 & 61 & 122 & 61 & 4 \\
\hline APR. & 55 & 25 & 30 & 76 & 76 & 76 & 0 \\
\hline MAY & 11 & 5 & 6 & 97 & 0 & 0 & 0 \\
\hline JUN. & 4 & 2 & 2 & 122 & 0 & 0 & 0 \\
\hline JUL. & 6 & 2 & 4 & 112 & 0 & 0 & 0 \\
\hline AUG & 8 & 2 & 6 & 114 & 0 & 0 & 0 \\
\hline SEPT. & 21 & 2 & 19 & 98 & 0 & 0 & 0 \\
\hline Total & 1112 & 436 & 676 & 860 & & 256 & 242 \\
\hline
\end{tabular}

Table 26b. Estimate of upper limit groundwater recharge from precipitation for Kehoe-Inverness-Sheridan soil in Study Area III (SM =61 $\mathrm{mm}$ ).

\begin{tabular}{|c|c|c|c|c|c|c|c|}
\hline Month & $\begin{array}{l}\text { Precip. } \\
(\mathrm{mm})\end{array}$ & $\begin{array}{l}\text { Runoff } \\
(\mathrm{mm})\end{array}$ & $\begin{array}{r}\text { Effective } \\
\text { Precip. } \\
\text { ( } \mathrm{mm} \text { ) }\end{array}$ & $\begin{array}{r}\text { Potential } \\
\text { ET. } \\
(\mathrm{m} \mathrm{m})\end{array}$ & $\begin{array}{r}\text { Accum. Soil } \\
\text { Moisture } \\
(\mathrm{m} \mathrm{m})\end{array}$ & $\begin{array}{l}\text { Actual } \\
\text { ET. } \\
(\mathrm{m} \mathrm{m})\end{array}$ & $\begin{array}{r}\text { G.W. } \\
\text { Recharge } \\
(\mathrm{m} \mathrm{m})\end{array}$ \\
\hline CT. & 72 & 2 & 70 & 66 & 4 & 4 & 0 \\
\hline NOV. & 185 & 20 & 165 & 30 & 61 & 30 & 74 \\
\hline DEC. & 197 & 59 & 138 & 17 & 61 & 17 & 121 \\
\hline JAN. & 216 & 112 & 104 & 31 & 61 & 31 & 73 \\
\hline FEB. & 184 & 117 & 67 & 36 & 61 & 36 & 31 \\
\hline MAR. & 153 & 88 & 65 & 61 & 61 & 36 & 4 \\
\hline APR. & 55 & 25 & 30 & 76 & 15 & 15 & 0 \\
\hline MAY & 11 & 5 & 6 & 97 & 0 & 0 & 0 \\
\hline JUN. & 4 & 2 & 2 & 122 & 0 & 0 & 0 \\
\hline JUL. & 6 & 2 & 4 & 112 & 0 & 0 & 0 \\
\hline AUG. & 8 & 2 & 6 & 114 & 0 & 0 & 0 \\
\hline SEPT. & 21 & 2 & 19 & 98 & 0 & 0 & 0 \\
\hline Total & 1112 & 436 & 676 & 860 & & 168 & 303 \\
\hline
\end{tabular}


Table 27a. Estimate of lower limit groundwater recharge from precipitation for Palomarin-Wittenberg soil in Study Area III $(S M=183 \mathrm{~mm})$.

$\begin{array}{lrrrrrrr} & \begin{array}{rrrr}\text { Precip. } \\ (\mathrm{m} \mathrm{m})\end{array} & \begin{array}{r}\text { Runoff } \\ (\mathrm{m} \mathrm{m})\end{array} & \begin{array}{r}\text { Effective } \\ \text { Precip. } \\ (\mathrm{m} \mathrm{m})\end{array} & \begin{array}{r}\text { Potential } \\ \text { ET. } \\ \text { Month }\end{array} & \begin{array}{r}\mathrm{m} \mathrm{m}) \\ \text { Accum. Soil } \\ \text { Moisture } \\ (\mathrm{m} \mathrm{m})\end{array} & \begin{array}{r}\text { Actual } \\ (\mathrm{m} \mathrm{m})\end{array} & \begin{array}{r}\text { Recharge } \\ (\mathrm{m} \mathrm{m})\end{array} \\ \text { NOT. } & 72 & 2 & 70 & 66 & 4 & 4 & 0 \\ \text { NOV. } & 185 & 20 & 165 & 30 & 135 & 30 & 0 \\ \text { DEC. } & 197 & 59 & 138 & 17 & 183 & 17 & 73 \\ \text { JAN. } & 216 & 112 & 104 & 31 & 183 & 31 & 73 \\ \text { FEB. } & 184 & 117 & 67 & 36 & 183 & 36 & 31 \\ \text { MAR. } & 153 & 88 & 65 & 61 & 183 & 61 & 4 \\ \text { APR. } & 55 & 25 & 30 & 76 & 137 & 76 & 0 \\ \text { MAY } & 11 & 5 & 6 & 97 & 46 & 46 & 0 \\ \text { JUN. } & 4 & 2 & 2 & 122 & 0 & 0 & 0 \\ \text { JUL. } & 6 & 2 & 4 & 112 & 0 & 0 & 0 \\ \text { AUG. } & 8 & 2 & 6 & 114 & 0 & 0 & 0 \\ \text { SEPT. } & 21 & 2 & 19 & 98 & 0 & 0 & 0 \\ \text { Total } & 1112 & 436 & 676 & 860 & & 301 & 181\end{array}$

Table 27b. Estimate of upper limit groundwater recharge from precipitaion for Palomarin-Wittenberg soil in Study Area III (SM = $122 \mathrm{~mm})$.

\begin{tabular}{|c|c|c|c|c|c|c|c|}
\hline Month & $\begin{array}{l}\text { Precip. } \\
(\mathrm{m} \mathrm{m})\end{array}$ & $\begin{array}{l}\text { Runoff } \\
(m, m)\end{array}$ & $\begin{array}{r}\text { Effective } \\
\text { Precip. } \\
(\mathrm{mm})\end{array}$ & $\begin{array}{r}\text { Potential } \\
\text { ET. } \\
(\mathrm{mm})\end{array}$ & $\begin{array}{r}\text { Accum. Soil } \\
\text { Moisture } \\
(\mathrm{m} \mathrm{m})\end{array}$ & $\begin{array}{r}\text { Actual } \\
\text { ET. } \\
(\mathrm{mm})\end{array}$ & $\begin{array}{r}\text { G.W. } \\
\text { Recharge } \\
(\mathrm{mm})\end{array}$ \\
\hline$\infty \mathrm{CT}$. & 72 & 2 & 70 & 66 & 4 & 4 & 0 \\
\hline NOV. & 185 & 20 & 165 & 30 & 122 & 30 & 13 \\
\hline DEC. & 197 & 59 & 138 & 17 & 122 & 17 & 121 \\
\hline JAî̀. & 216 & 112 & 104 & 31 & 122 & 31 & 73 \\
\hline FEB. & 184 & 117 & 67 & 36 & 122 & 36 & 31 \\
\hline MAR. & 153 & 88 & 65 & 61 & 122 & 61 & 4 \\
\hline APR. & 55 & 25 & 30 & 76 & 76 & 76 & 0 \\
\hline MAY & 11 & 5 & 6 & 97 & 0 & 0 & 0 \\
\hline JUN. & 4 & 2 & 2 & 122 & 0 & C & 0 \\
\hline . أن'ا. & 6 & 2 & 4 & 112 & 0 & 0 & 0 \\
\hline AUG & 8 & 2 & 6 & 114 & 0 & 0 & 0 \\
\hline SEPT. & 21 & 2 & 19 & 98 & 0 & 0 & 0 \\
\hline Total & 1112 & 436 & 676 & 860 & & 255 & 242 \\
\hline
\end{tabular}


Table 28a. Estimate of lower limit groundwater recharge from precipitation for Cronkite-Dipsea-Centissimma soil in Study Area III (SM $=168 \mathrm{~mm}$ ).

\begin{tabular}{|c|c|c|c|c|c|c|c|}
\hline Month & $\begin{array}{l}\text { Precip. } \\
(\mathrm{m} \mathrm{m})\end{array}$ & $\begin{array}{l}\text { Runoff } \\
(\mathrm{m} \mathrm{m})\end{array}$ & $\begin{array}{r}\text { Effective } \\
\text { Precip. } \\
(\mathrm{mm})\end{array}$ & $\begin{array}{r}\text { Potential } \\
\text { ET. } \\
(\mathrm{mm})\end{array}$ & $\begin{array}{r}\text { Accum. Soil } \\
\text { Moisture } \\
(\mathrm{mm})\end{array}$ & $\begin{array}{c}\text { Actual } \\
\text { ET. } \\
(\mathrm{mm})\end{array}$ & $\begin{array}{r}\text { G.W. } \\
\text { Recharge } \\
(\mathrm{m} \mathrm{m})\end{array}$ \\
\hline œT. & 72 & 2 & 70 & 66 & 4 & 4 & 0 \\
\hline NOV. & 185 & 20 & 165 & 30 & 135 & 30 & 0 \\
\hline DEC. & 197 & 59 & 138 & 17 & 168 & 17 & 88 \\
\hline JAN. & 216 & 112 & 104 & 31 & 168 & 31 & 73 \\
\hline FEB. & 184 & 117 & 67 & 36 & 168 & 36 & 31 \\
\hline MAR. & 153 & 88 & 65 & 61 & 168 & 61 & 4 \\
\hline APR. & 55 & 25 & 30 & 76 & 122 & 76 & 0 \\
\hline MAY & 11 & 5 & 6 & 97 & 32 & 32 & 0 \\
\hline JUN. & 4 & 2 & 2 & 122 & 0 & 0 & 0 \\
\hline JUL. & 6 & 2 & 4 & 112 & 0 & 0 & 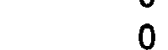 \\
\hline AUG & 8 & 2 & 6 & 114 & 0 & 0 & 0 \\
\hline SEPT. & 21 & 2 & 19 & 98 & 0 & 0 & 0 \\
\hline Total & 1112 & 436 & 676 & 860 & & 287 & \\
\hline
\end{tabular}

Table 28b. Estimate of upper limit groundwater recharge from precipitation for Cronkite-Dipsea-Centissimma soil in Study Area III (SM $=102 \mathrm{~mm}$ ).

\begin{tabular}{|c|c|c|c|c|c|c|c|}
\hline Month & $\begin{array}{r}\text { Precip. } \\
(\mathrm{mm})\end{array}$ & $\begin{array}{l}\text { Runoff } \\
(\mathrm{m} \mathrm{m})\end{array}$ & $\begin{array}{r}\text { Effective } \\
\text { Precip. } \\
(\mathrm{mm})\end{array}$ & $\begin{array}{r}\text { Potential } \\
\text { ET. } \\
(\mathrm{m} \mathrm{m})\end{array}$ & $\begin{array}{r}\text { Accum. Soil } \\
\text { Moisture } \\
(\mathrm{mm})\end{array}$ & $\begin{array}{r}\text { Actual } \\
E T . \\
(\mathrm{mm})\end{array}$ & $\begin{array}{r}\text { G.W. } \\
\text { Recharge } \\
(\mathrm{m} \mathrm{m})\end{array}$ \\
\hline OCT. & 72 & 2 & 70 & 66 & 4 & 4 & 0 \\
\hline NOV. & 185 & 20 & 165 & 30 & 102 & 30 & 33 \\
\hline DEC. & 197 & 59 & 138 & 17 & 102 & 17 & 121 \\
\hline JAN. & 216 & 112 & 104 & 31 & 102 & 31 & 73 \\
\hline FEB. & 184 & 117 & 67 & 36 & 102 & 36 & 31 \\
\hline MAR. & 153 & 88 & 65 & 61 & 102 & 61 & 4 \\
\hline APR. & 55 & 25 & 30 & 76 & 56 & 56 & 0 \\
\hline MAY & 11 & 5 & 6 & 97 & 0 & 0 & 0 \\
\hline JUN. & 4 & 2 & 2 & 122 & 0 & 0 & 0 \\
\hline JUL. & 6 & 2 & 4 & 112 & 0 & 0 & 0 \\
\hline AUG. & 8 & 2 & 6 & 114 & 0 & 0 & 0 \\
\hline SEPT. & 21 & 2 & 19 & 98 & 0 & 0 & 0 \\
\hline Total & 1112 & 436 & 676 & 860 & & 235 & 262 \\
\hline
\end{tabular}


Table 29a. Estimate of lower limit groundwater recharge from precipitation for Olompali-Felton-Soulajoule soil in Study Area III (SM = $213 \mathrm{~mm})$.

\begin{tabular}{|c|c|c|c|c|c|c|c|}
\hline Month & $\begin{array}{r}\text { Precip. } \\
\text { (m m) }\end{array}$ & $\begin{array}{l}\text { Runoff } \\
(\mathrm{m} \mathrm{m})\end{array}$ & $\begin{array}{r}\text { Effective } \\
\text { Precip. } \\
(\mathrm{mm})\end{array}$ & $\begin{array}{r}\text { Potential' } \\
\text { ET. } \\
(\mathrm{mm})\end{array}$ & $\begin{array}{r}\text { Accum. Soil } \\
\text { Moisture } \\
(\mathrm{mm})\end{array}$ & $\begin{array}{r}\text { Actual } \\
\text { ET. } \\
(\mathrm{mm})\end{array}$ & $\begin{array}{r}\text { G.W. } \\
\text { Recharge } \\
(\mathrm{m} \mathrm{m})\end{array}$ \\
\hline$\infty$ T. & 72 & 2 & 70 & 66 & 4 & 4 & 0 \\
\hline NOV. & 185 & 20 & 165 & 30 & 139 & 30 & 0 \\
\hline DEC. & 197 & 59 & 138 & 17 & 213 & 17 & 43 \\
\hline JAN. & 216 & 112 & 104 & 31 & 213 & 31 & 73 \\
\hline FEB. & 184 & 117 & 67 & 36 & 213 & 36 & 3 \\
\hline MAR. & 153 & 88 & 65 & 61 & 213 & 61 & \\
\hline APR. & 55 & 25 & 30 & 76 & 167 & 76 & \\
\hline MAY & 11 & 5 & 6 & 97 & 77 & 77 & \\
\hline JUN. & 4 & 2 & 2 & 122 & 0 & 0 & \\
\hline JUL. & 6 & 2 & 4 & 112 & 0 & 0 & \\
\hline ALG. & 8 & 2 & 6 & 114 & 0 & 0 & \\
\hline SEPT. & 21 & 2 & 19 & 98 & 0 & 0 & \\
\hline otal & 1112 & 436 & 676 & 860 & & 332 & 75 \\
\hline
\end{tabular}

Table 29b. Estimate of upper limit groundwater recharge from precipitation for Olompali-Felton-Soulajoule soil in Study Area III (SM = $142 \mathrm{~mm}$ ).

\begin{tabular}{|c|c|c|c|c|c|c|c|}
\hline Month & $\begin{array}{l}\text { Precip. } \\
(\mathrm{mm})\end{array}$ & $\begin{array}{l}\text { Runoff } \\
(\mathrm{mm})\end{array}$ & $\begin{array}{r}\text { Effective } \\
\text { Precip. } \\
(\mathrm{mm})\end{array}$ & $\begin{array}{r}\text { Potential } \\
E T . \\
(\mathrm{mm})\end{array}$ & $\begin{array}{r}\text { Accum. Soil } \\
\text { Moisture } \\
(\mathrm{mm})\end{array}$ & $\begin{array}{r}\text { Actual } \\
E T . \\
(\mathrm{m} \mathrm{m})\end{array}$ & $\begin{array}{r}\text { G.W } \\
\text { Recharge } \\
(\mathrm{mm})\end{array}$ \\
\hline$\infty$ T. & 72 & 2 & 70 & 66 & 4 & 4 & 0 \\
\hline NOV. & 185 & 20 & 165 & 30 & 135 & 30 & 0 \\
\hline DEC. & 197 & 59 & 138 & 17 & 142 & 17 & 115 \\
\hline JAN. & 216 & 112 & 104 & 31 & 142 & 31 & 73 \\
\hline FEB. & 184 & 117 & 67 & 36 & 142 & 36 & 31 \\
\hline MAR. & 153 & 88 & 65 & 61 & 142 & 61 & 4 \\
\hline APR. & 55 & 25 & 30 & 76 & 96 & 76 & 0 \\
\hline MAY & 11 & 5 & 6 & 97 & 5 & 5 & 0 \\
\hline JUN. & 4 & 2 & 2 & 122 & 0 & 0 & 0 \\
\hline JUL. & 6 & 2 & 4 & 112 & 0 & 0 & 0 \\
\hline AUG. & 8 & 2 & 6 & $1 i 4$ & 0 & 0 & 0 \\
\hline SEPT. & 21 & 2 & 19 & 98 & 0 & 0 & 0 \\
\hline Total & 1112 & 436 & 676 & 860 & & 260 & 223 \\
\hline
\end{tabular}


Table 30a. Estimate of lower limit groundwater recharge from precipitation for Tocaloma-Saurin soil in Study Area III $(S M=152 \mathrm{~mm})$.

\begin{tabular}{|c|c|c|c|c|c|c|c|}
\hline Month & $\begin{array}{l}\text { Precip. } \\
\text { (mm) }\end{array}$ & $\begin{array}{l}\text { Runoff } \\
(\mathrm{m} \mathrm{m})\end{array}$ & $\begin{array}{r}\text { Effective } \\
\text { Precip. } \\
\text { (m m) }\end{array}$ & $\begin{array}{r}\text { Potential } \\
\text { ET. } \\
(\mathrm{mm})\end{array}$ & $\begin{array}{r}\text { Accum. Soil } \\
\text { Moisture } \\
(\mathrm{mm})\end{array}$ & $\begin{array}{r}\text { Actual } \\
\text { ET. } \\
(\mathrm{mm})\end{array}$ & $\begin{array}{r}\text { G.W. } \\
\text { Recharge } \\
(\mathrm{m} \mathrm{m})\end{array}$ \\
\hline OCT. & 72 & 2 & 70 & 66 & 4 & 4 & 0 \\
\hline NOV. & 185 & 20 & 165 & 30 & 135 & 30 & 0 \\
\hline DEC. & 197 & 59 & 138 & 17 & 152 & 17 & 104 \\
\hline JAN. & 216 & 112 & 104 & 31 & 152 & 31 & 73 \\
\hline FEB. & 184 & 117 & 67 & 36 & 152 & 36 & 31 \\
\hline MAR. & 153 & 88 & 65 & 61 & 152 & 61 & 4 \\
\hline APR. & 55 & 25 & 30 & 76 & 106 & 76 & 0 \\
\hline MAY & 11 & 5 & 6 & 97 & 16 & 16 & 0 \\
\hline JUN. & 4 & 2 & 2 & 122 & 0 & 0 & 0 \\
\hline JUL. & 6 & 2 & 4 & 112 & 0 & 0 & 0 \\
\hline AUG. & 8 & 2 & 6 & 114 & 0 & 0 & 0 \\
\hline SEPT. & 21 & 2 & 19 & 98 & 0 & 0 & 0 \\
\hline Total & 1112 & 436 & 676 & 860 & & 271 & 212 \\
\hline
\end{tabular}

Table 30b. Estimate of upper limit groundwater recharge from precipitaion for Tocaloma soil in Study Area III (SM $=76 \mathrm{~mm})$.

$\begin{array}{lrrrrrrr} & \text { Precip. } & \begin{array}{r}\text { Runoff } \\ (\mathrm{mm})\end{array} & \begin{array}{r}\text { Effective } \\ \text { Precip. } \\ (\mathrm{m} \mathrm{m})\end{array} & \begin{array}{r}\text { Potential } \\ \text { ET. } \\ (\mathrm{m} \mathrm{m})\end{array} & \begin{array}{r}\text { Accum. Soil } \\ \text { Moisture } \\ (\mathrm{m} \mathrm{m})\end{array} & \begin{array}{r}\text { Actual } \\ (\mathrm{m} \mathrm{m})\end{array} & \begin{array}{r}\text { Recharge } \\ (\mathrm{m} \mathrm{m})\end{array} \\ \text { OCT. } & 72 & 2 & 70 & 66 & 4 & 4 & 0 \\ \text { NOV. } & 185 & 20 & 165 & 30 & 76 & 30 & 59 \\ \text { DEC. } & 197 & 59 & 138 & 17 & 76 & 17 & 121 \\ \text { JAN. } & 216 & 112 & 104 & 31 & 76 & 31 & 73 \\ \text { FEB. } & 184 & 117 & 67 & 36 & 76 & 36 & 31 \\ \text { MAR. } & 153 & 88 & 65 & 61 & 76 & 61 & 4 \\ \text { APR. } & 55 & 25 & 30 & 76 & 30 & 30 & 0 \\ \text { MAY } & 11 & 5 & 6 & 97 & 0 & 0 & 0 \\ \text { JUN. } & 4 & 2 & 2 & 122 & 0 & 0 & 0 \\ \text { JUL. } & 6 & 2 & 4 & 112 & 0 & 0 & 0 \\ \text { AUG. } & 8 & 2 & 6 & 114 & 0 & 0 & 0 \\ \text { SEPT. } & 21 & 2 & 19 & 98 & 0 & 0 & 0 \\ \text { Total } & 1112 & 436 & 676 & 860 & & 209 & 288\end{array}$


Table 31a. Estimate of lower limit groundwater recharge from precipitation for Los Osos-Bonnydoon soil in Study area III (SM = $124 \mathrm{~mm}$ ).

\begin{tabular}{|c|c|c|c|c|c|c|c|}
\hline Morith & $\begin{array}{l}\text { Precip. } \\
(\mathrm{m} \mathrm{m})\end{array}$ & $\begin{array}{l}\text { Runoff } \\
(\mathrm{mm})\end{array}$ & $\begin{array}{r}\text { Effective } \\
\text { Precip. } \\
(\mathrm{m} \mathrm{m})\end{array}$ & $\begin{array}{r}\text { Potential } \\
E T . \\
(\mathrm{mm})\end{array}$ & $\begin{array}{r}\text { Accum. Soil } \\
\text { Moisture } \\
(\mathrm{m} \mathrm{m})\end{array}$ & $\begin{array}{l}\text { Actual } \\
E T . \\
(\mathrm{m} \mathrm{m})\end{array}$ & $\begin{array}{r}\text { G.W. } \\
\text { Recharge } \\
(\mathrm{m} \mathrm{m})\end{array}$ \\
\hline$\infty$ œT. & 72 & 2 & 70 & 66 & 4 & 4 & 0 \\
\hline NOV. & 185 & 20 & 165 & 30 & 124 & 30 & 11 \\
\hline DEC. & 197 & 59 & 138 & 17 & 124 & 17 & 121 \\
\hline JAN. & 216 & 112 & 104 & 31 & 124 & 31 & 73 \\
\hline FEB. & 184 & 117 & 67 & 36 & 124 & 36 & 31 \\
\hline MAR. & 153 & 88 & 65 & 61 & 124 & 61 & \\
\hline APR. & 55 & 25 & 30 & 76 & 78 & 76 & 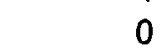 \\
\hline MAY & 11 & 5 & 5 & 97 & 1 & 1 & 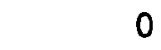 \\
\hline JUN. & 4 & 2 & 2 & 122 & 0 & 0 & 0 \\
\hline JUL. & 6 & 2 & 4 & 112 & 0 & 0 & 0 \\
\hline AUG. & 8 & 2 & 6 & 114 & 0 & 0 & 0 \\
\hline SEPT. & 21 & 2 & 19 & 98 & 0 & 0 & \\
\hline Total & 1112 & 436 & 676 & 860 & & 256 & 24 \\
\hline
\end{tabular}

Table 31b. Estimate of upper limit groundwater recharge from precipitation for Los Osos-Bonnydoon soil in Study Area III (SM = $64 \mathrm{~mm})$.

\begin{tabular}{|c|c|c|c|c|c|c|c|}
\hline Month & $\begin{array}{l}\text { Precip. } \\
\text { (m m) }\end{array}$ & $\begin{array}{l}\text { Runoff } \\
(\mathrm{mm})\end{array}$ & $\begin{array}{l}\text { Effective } \\
\text { Precip. } \\
(\mathrm{mm})\end{array}$ & $\begin{array}{r}\text { Potential } \\
\text { ET. } \\
(\mathrm{mm})\end{array}$ & $\begin{array}{r}\text { Accum. Soil } \\
\text { Moisture } \\
(\mathrm{m} \mathrm{m})\end{array}$ & $\begin{array}{c}\text { Actual } \\
\text { ET. } \\
(\mathrm{m} \mathrm{m})\end{array}$ & $\begin{array}{r}\text { G.W. } \\
\text { Recharge } \\
(\mathrm{m} \mathrm{m})\end{array}$ \\
\hline œт. & 72 & 2 & 70 & 66 & 4 & 4 & v \\
\hline NOY. & 185 & 20 & 165 & 30 & 64 & 30 & 71 \\
\hline DEC. & 197 & 59 & 138 & 17 & 64 & 17 & 121 \\
\hline JAN. & 216 & 112 & 104 & 31 & 64 & $\varepsilon 1$ & 74 \\
\hline FEB. & 184 & 117 & 67 & 36 & 64 & 36 & 3 \\
\hline MAR. & 153 & 88 & 65 & 61 & 64 & 61 & \\
\hline APR. & 55 & 25 & 30 & 76 & 18 & 18 & \\
\hline MAY & 11 & 5 & 6 & 97 & 0 & 0 & \\
\hline JUN. & 4 & 2 & 2 & 122 & 0 & 0 & \\
\hline JUL. & 6 & 2 & 4 & 112 & 0 & 0 & \\
\hline AUG. & 8 & 2 & 6 & 114 & 0 & 0 & 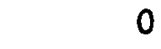 \\
\hline SEPT. & 21 & 2 & 19 & 98 & 0 & 0 & \\
\hline Total & 1112 & 436 & 676 & $8 f .0$ & & 197 & 23 \\
\hline
\end{tabular}




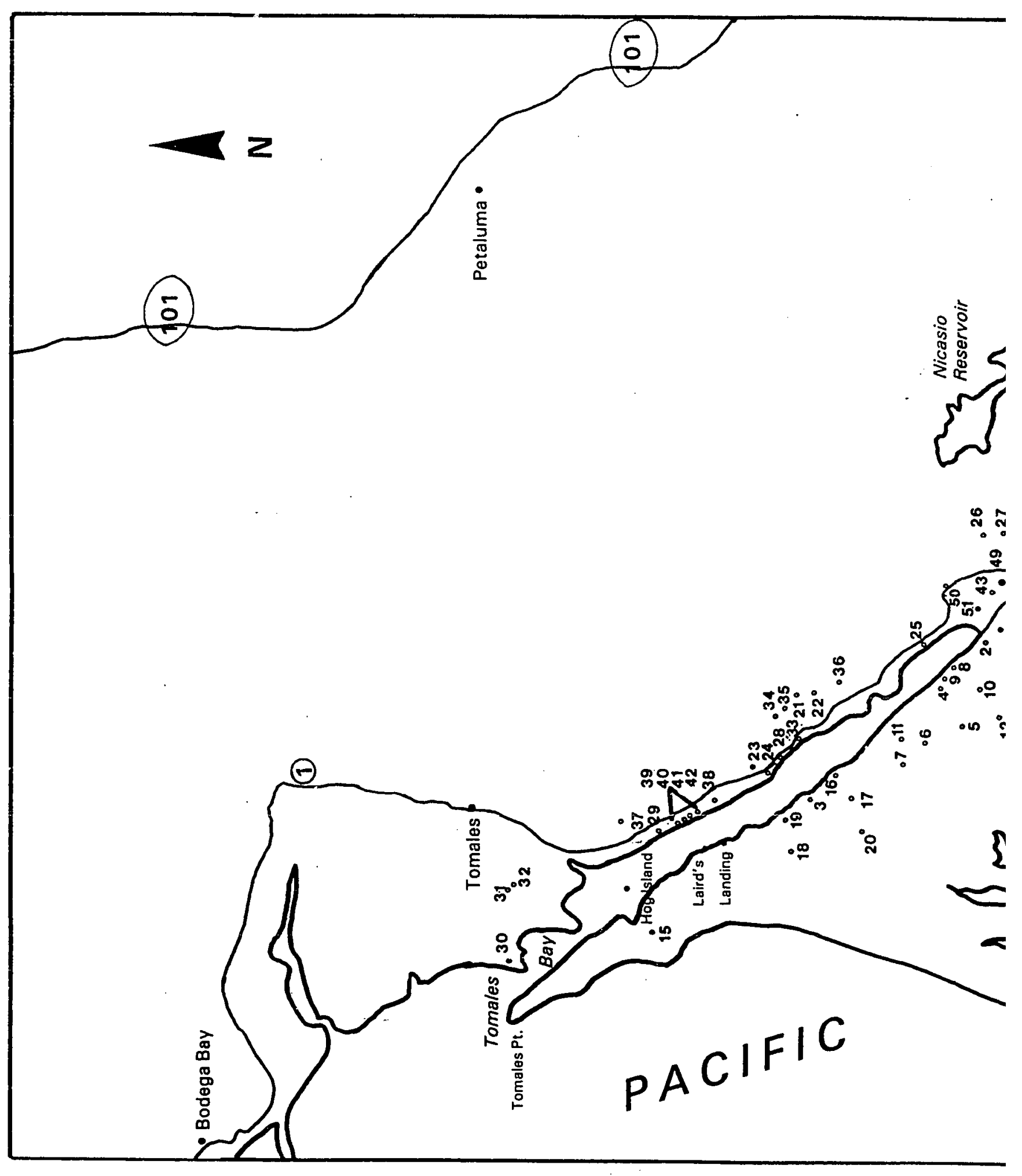





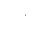




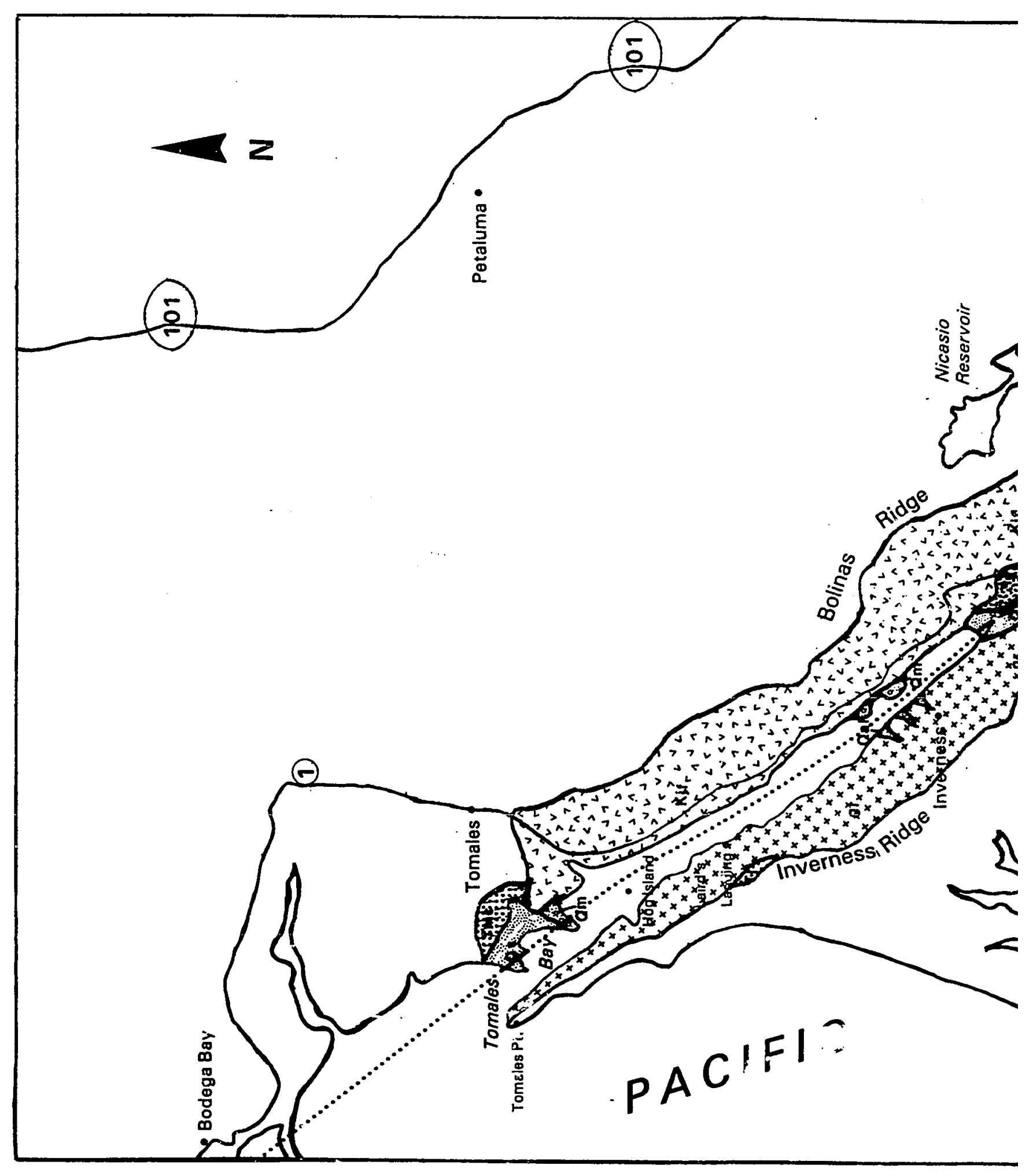






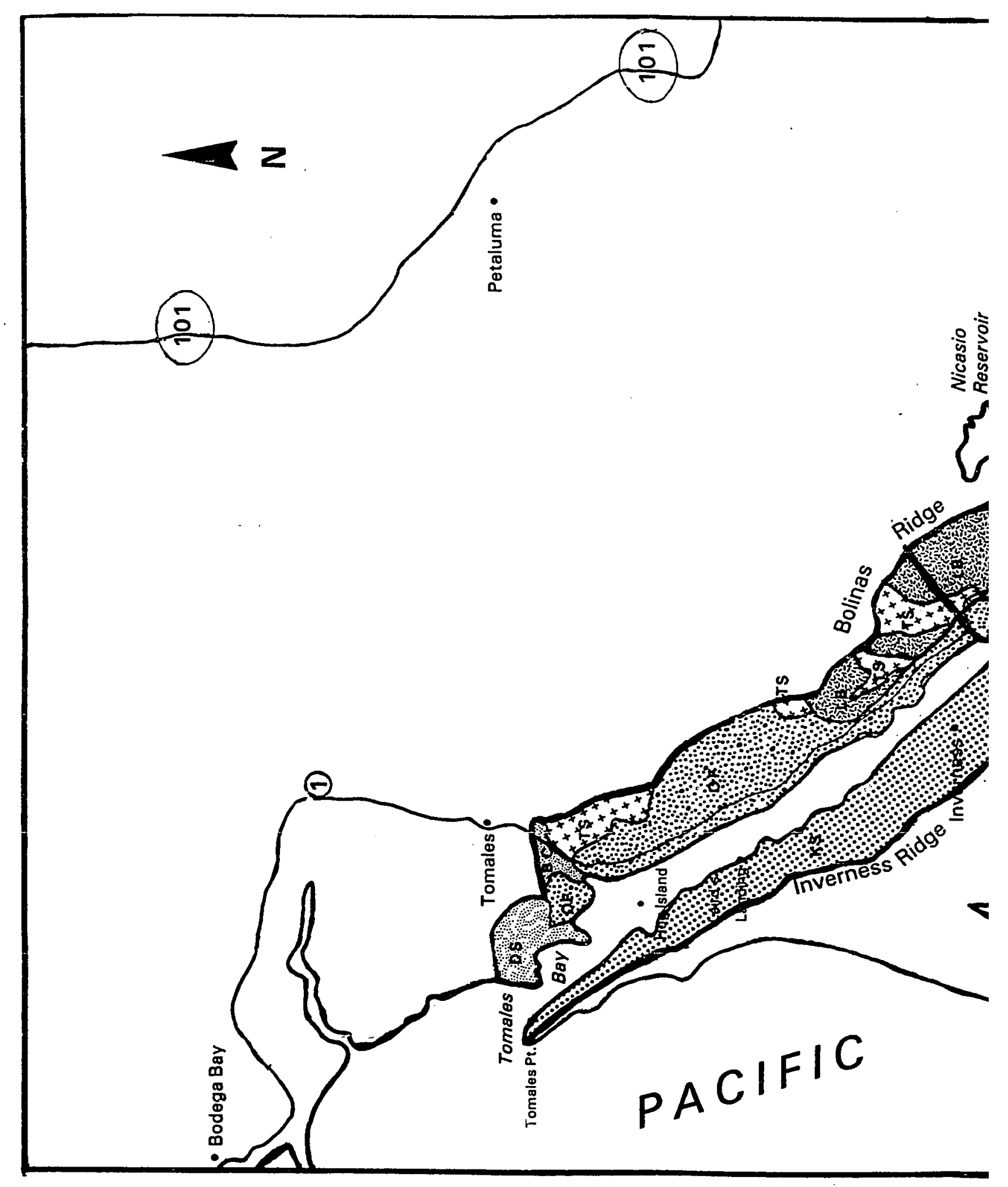




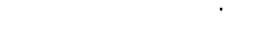

( 


\section{.}




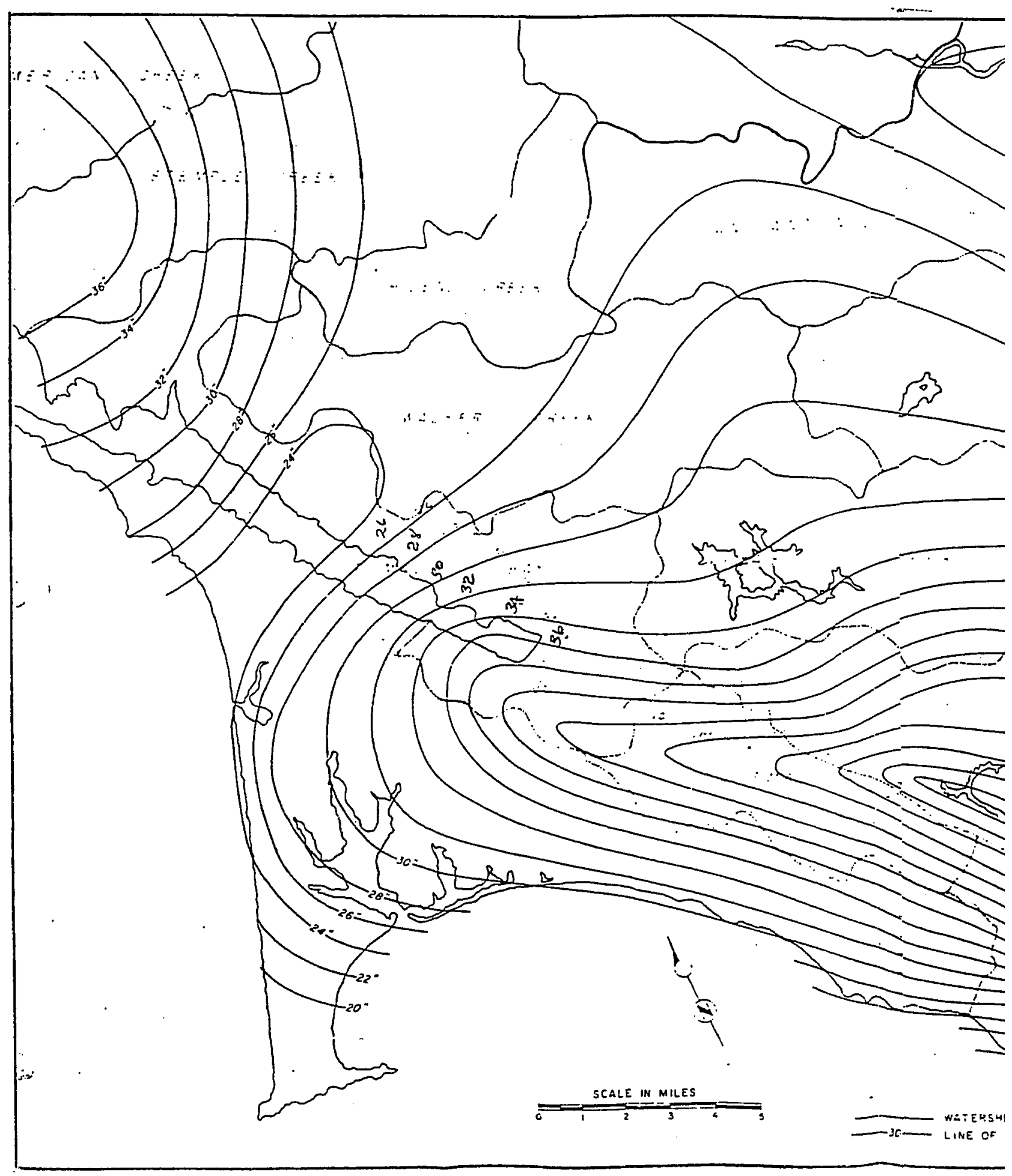

Plate 4. Isohyetal map of Marin County (USGS, unpublished). 



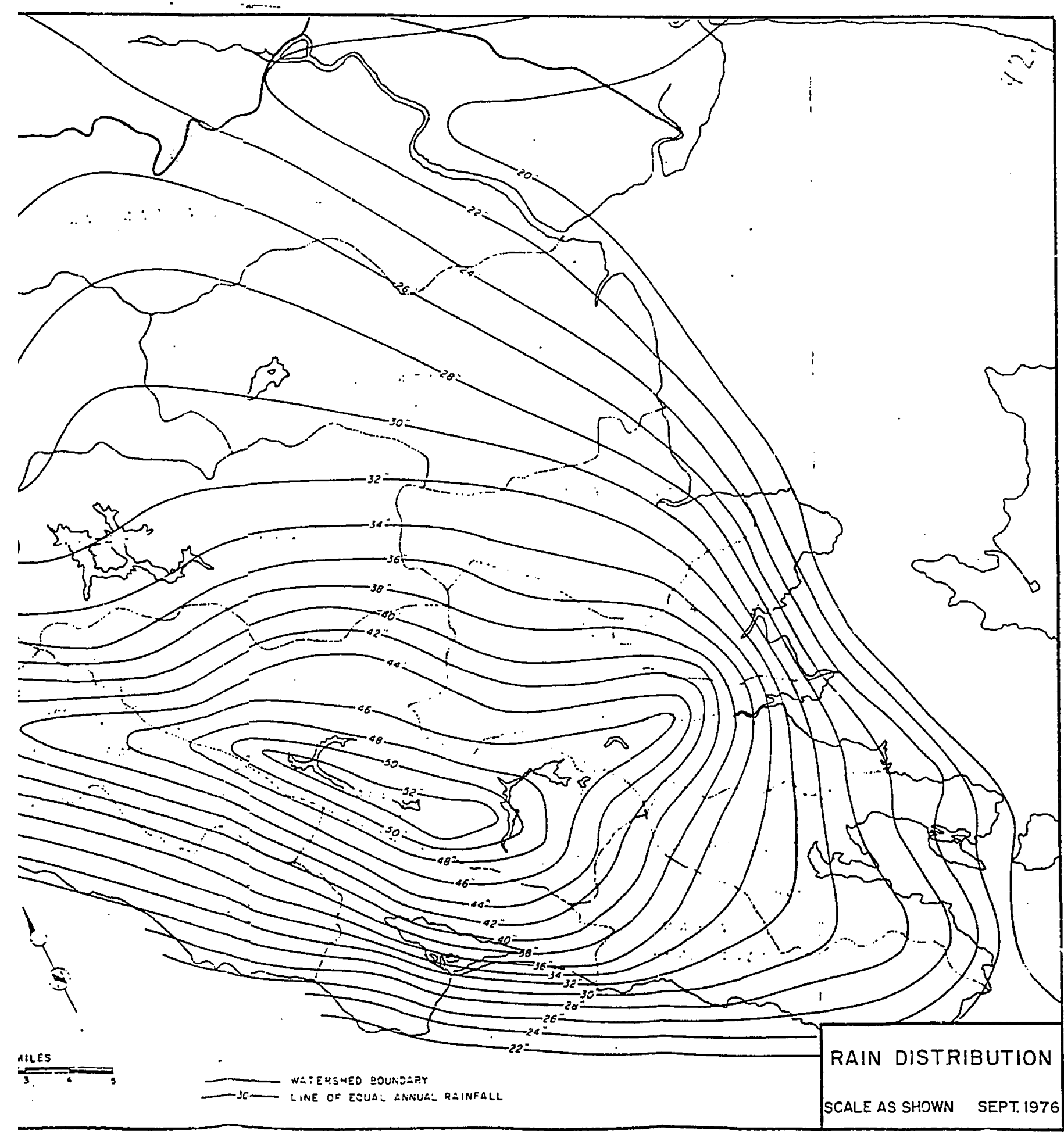

shed). 


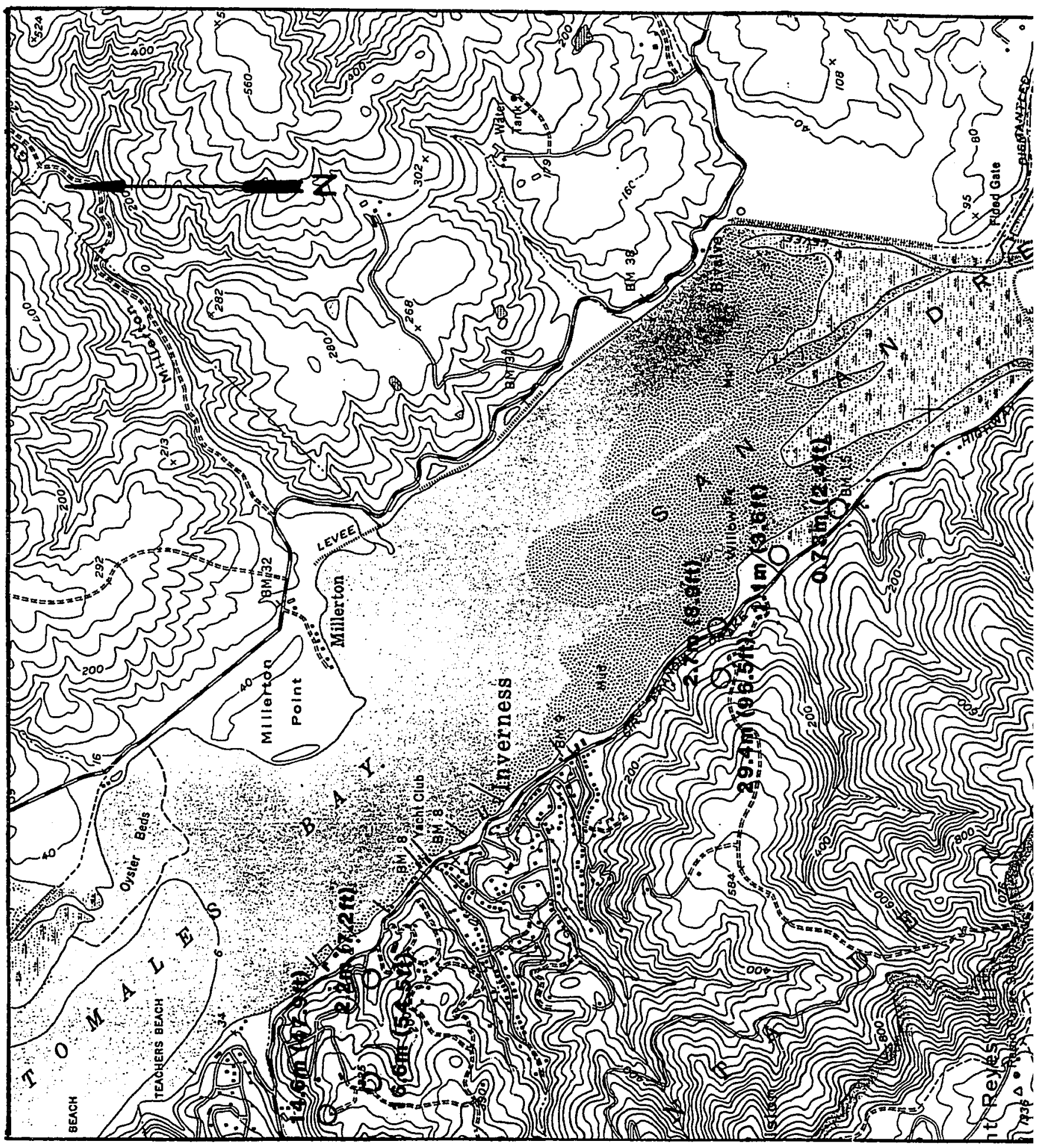



$\therefore$ 


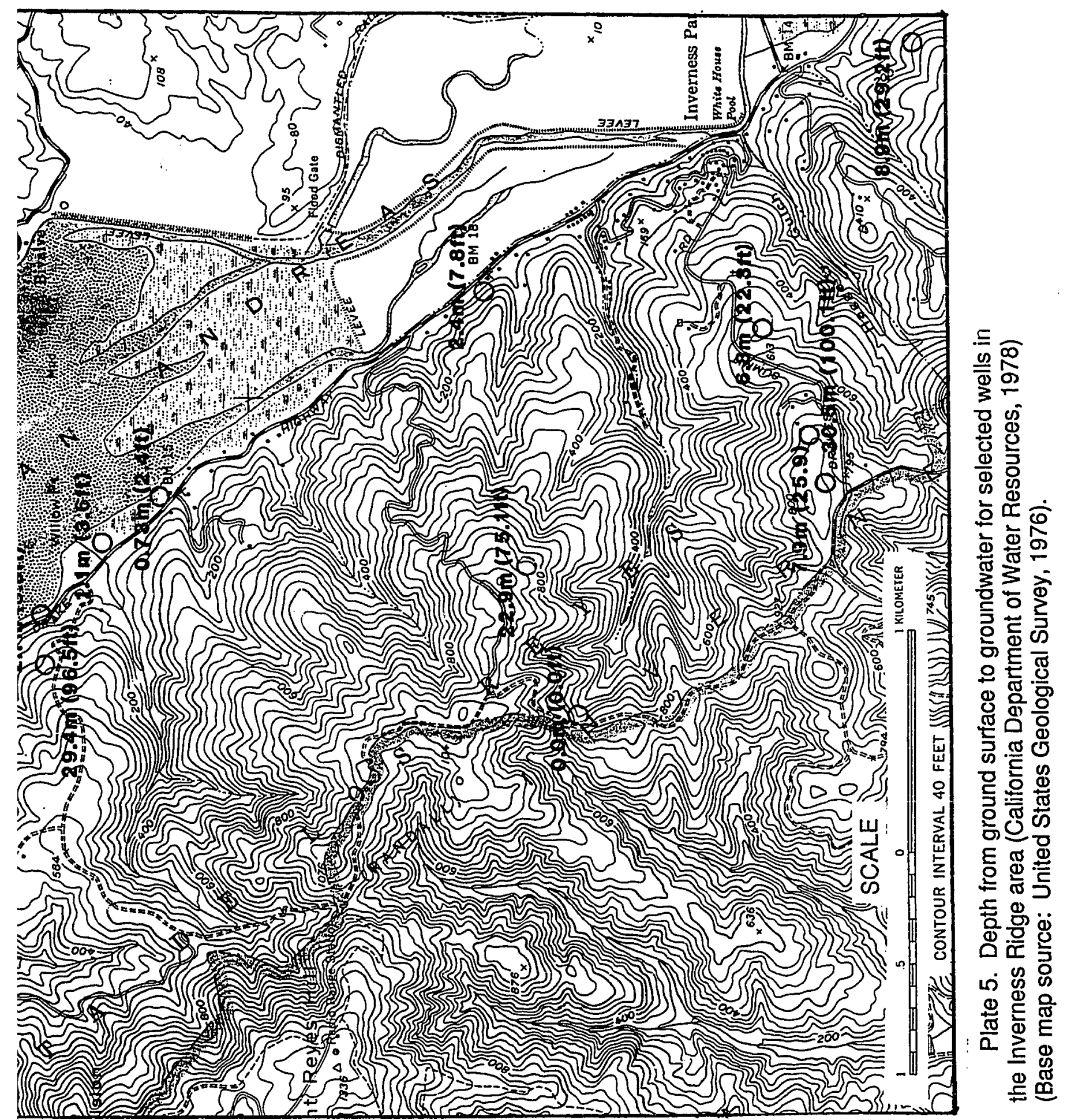

